Prepared for the U.S. Department of Energy under Contract DE-AC05-76RL01830

\title{
Municipal Solid Waste (MSW) to Liquid Fuels Synthesis, Volume 2: A Techno-economic Evaluation of the Production of Mixed Alcohols
}

\section{SB Jones}

Y Zhu

$C$ Valkenburg

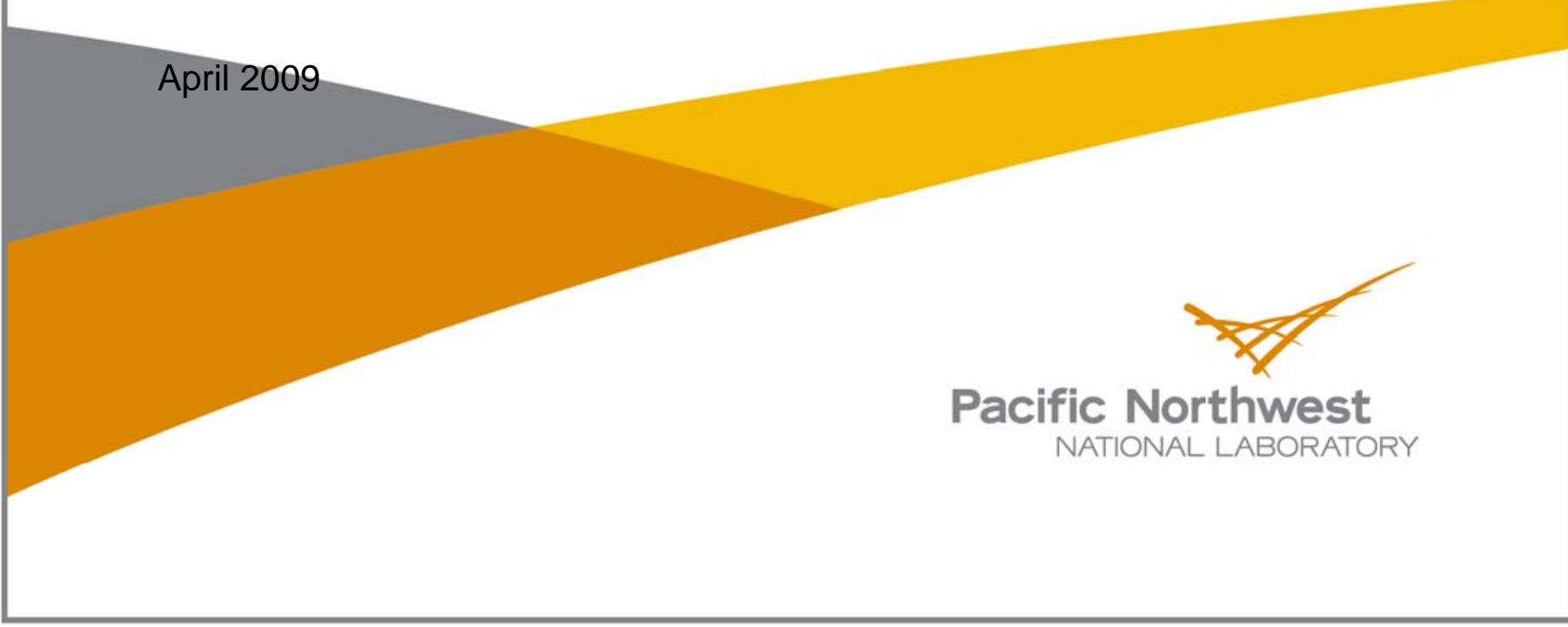




\title{
DISCLAIMER
}

United States Government. Neither the United States Government nor any agency thereof, nor Battelle Memorial Institute, nor any of their employees, makes any warranty, express or implied, or assumes any legal liability or responsibility for the accuracy, completeness, or usefulness of any information, apparatus, product, or process disclosed, or represents that its use would not infringe privately owned rights. Reference herein to any specific commercial product, process, or service by trade name, trademark, manufacturer, or otherwise does not necessarily constitute or imply its endorsement, recommendation, or favoring by the United States Government or any agency thereof, or Battelle Memorial Institute. The views and opinions of authors expressed herein do not necessarily state or reflect those of the United States Government or any agency thereof.

\author{
PACIFIC NORTHWEST NATIONAL LABORATORY \\ operated by \\ BATTELLE \\ for the \\ UNITED STATES DEPARTMENT OF ENERGY \\ under Contract DE-AC05-76RL01830 \\ Printed in the United States of America \\ Available to DOE and DOE contractors from the \\ Office of Scientific and Technical Information, \\ P.O. Box 62, Oak Ridge, TN 37831-0062; \\ ph: (865) 576-8401, fax: (865) 576-5728 \\ email: reports@adonis.osti.gov \\ Available to the public from the National Technical Information Service, \\ U.S. Department of Commerce, 5285 Port Royal Rd., Springfield, VA 22161 \\ ph: (800) 553-6847, fax: (703) 605-6900 \\ email: orders@ntis.fedworld.gov \\ online ordering: http://www.ntis.gov/ordering.htm
}

This document was printed on recycled paper.

$(8 / 00)$ 


\title{
Municipal Solid Waste (MSW) to Liquid Fuels Synthesis, Volume 2: A Techno-economic Evaluation of the Production of Mixed Alcohols
}

\author{
SB Jones \\ Y Zhu \\ C Valkenburg
}

April 2009

Prepared for U.S. Department of Energy under Contract DE-AC05-76RL01830

Pacific Northwest National Laboratory

Richland, Washington 99352 


\section{Summary}

Biomass is a renewable energy resource that can be converted into liquid fuel suitable for transportation applications and thus help meet the Energy Independence and Security Act renewable energy goals (U.S. Congress 2007). However, biomass is not always available in sufficient quantity at a price compatible with fuels production. Municipal solid waste (MSW) on the other hand is readily available in large quantities in some communities and is considered a partially renewable feedstock. Furthermore, MSW may be available for little or no cost.

This report provides a techno-economic analysis of the production of mixed alcohols from MSW and compares it to the costs for a wood based plant. In this analysis, MSW is processed into refuse derived fuel (RDF) and then gasified in a plant co-located with a landfill. The resulting syngas is then catalytically converted to mixed alcohols. At a scale of 2000 metric tons per day of RDF, and using current technology, the minimum ethanol selling price at a $10 \%$ rate of return is approximately $\$ 1.85 /$ gallon ethanol (early 2008 \$). However, favorable economics are dependent upon the toxicity characteristics of the waste streams and that a market exists for the by-product scrap metal recovered from the RDF process. 


\section{Acknowledgment}

The authors thank DOE's biomass program for funding this work and acknowledge the modeling work performed by the National Renewable Energy Laboratory (NREL), which serves as the basis for the gasification and syngas conditioning portion of the models. 


\section{Contents}

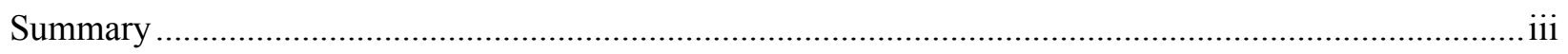

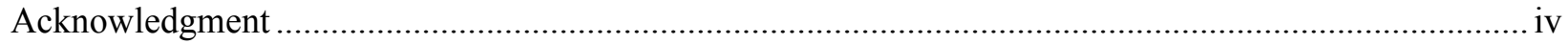

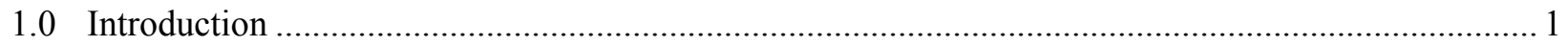

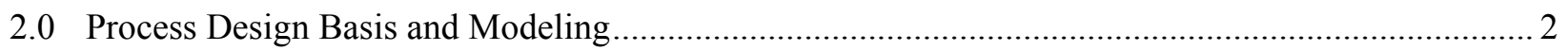

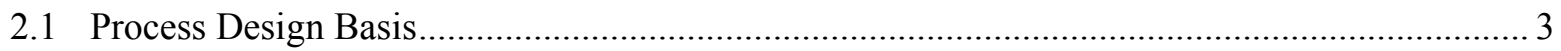

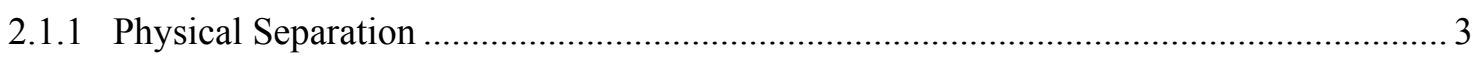

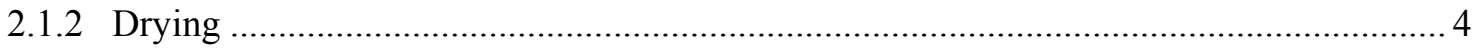

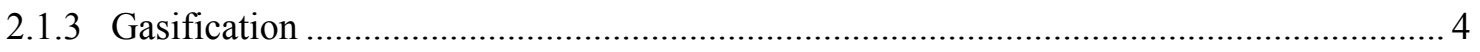

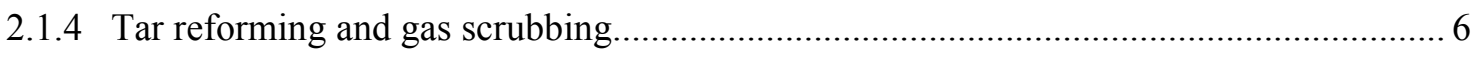

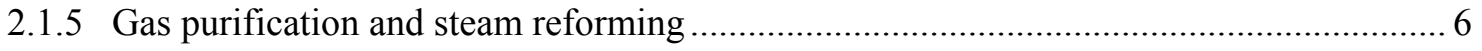

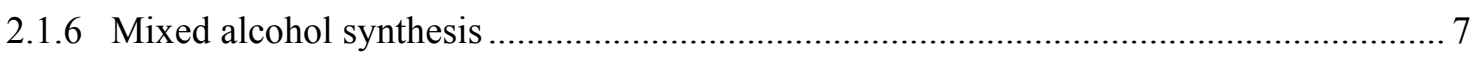

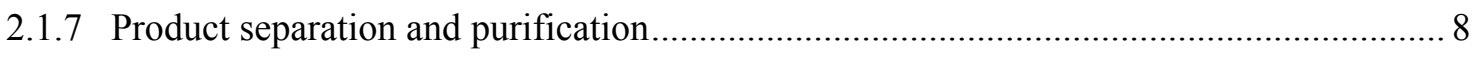

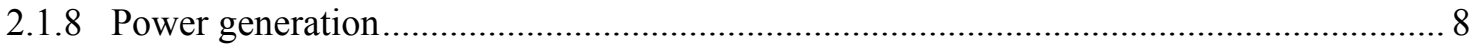

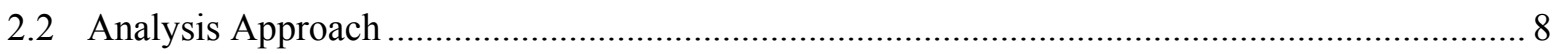

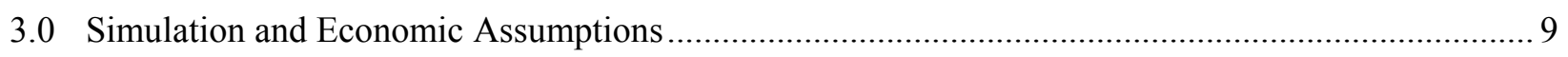

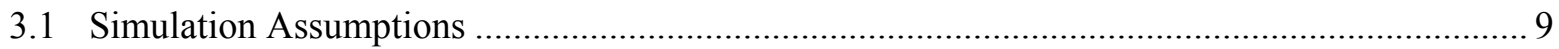

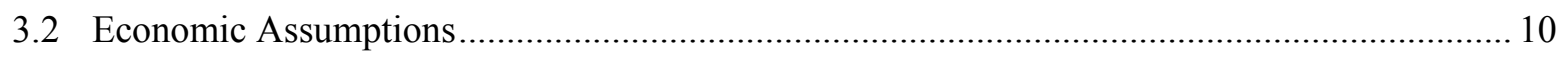

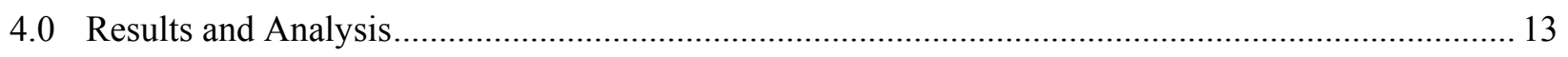

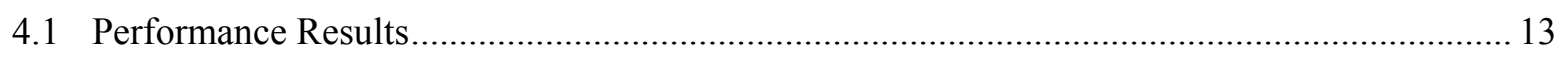

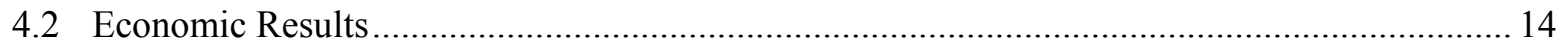

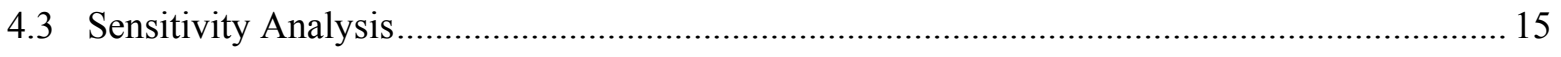

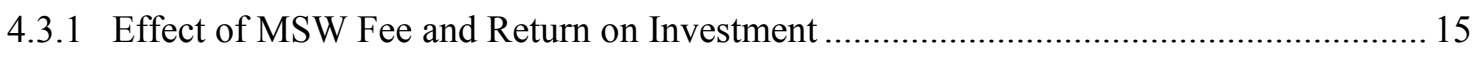

4.3.2 Effect of RDF Operating Schedule and MSW and By-Product Value............................ 17

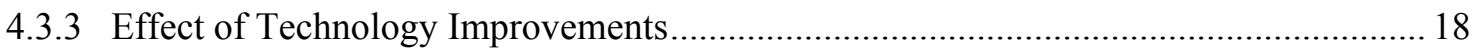

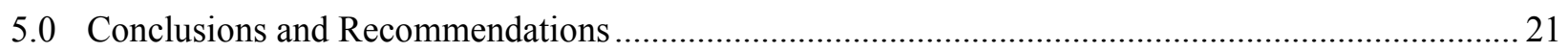

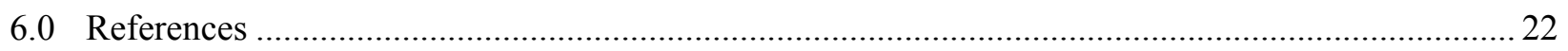

Appendix A. Heat and Material Balance for the Biomass Reference Case ........................................... 24

Appendix B. Heat and Material Balance for the MSW Case................................................................. 45

\section{Figures}

Figure 2-1 Process Diagram of the MSW to Ethanol Process ................................................................ 2

Figure 2-2 Process Diagram of the MSW to Ethanol Process .............................................................. 3

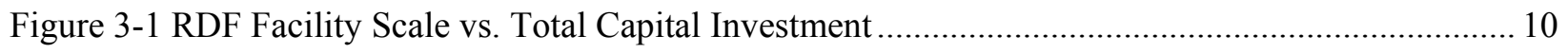




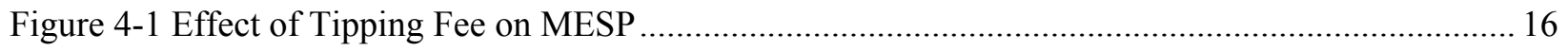

Figure 4-2 Effect of Tipping Fee on MESP at Different Rates of Return ........................................... 17

Figure 4-3 MESP Sensitivity to Process and Operating Changes......................................................... 18

Figure 4-4 Effect of Improved Technology …….............................................................................. 20

Figure A-1 Process Flow Diagram for the Biomass Reference Case ................................................... 25

Figure B-1 Process Flow Diagram for the MSW Case ...................................................................... 46

\section{Tables}

Table 2-1 Example Operating Schedules for RDF Production ........................................................... 4

Table 2-2 RDF and Biomass Feedstock Quality and Gasifier Conditions................................................. 5

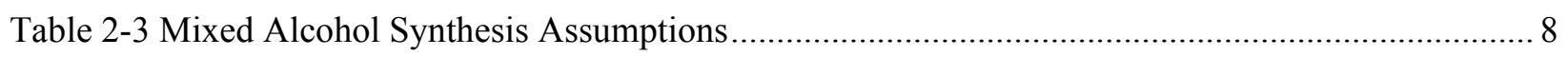

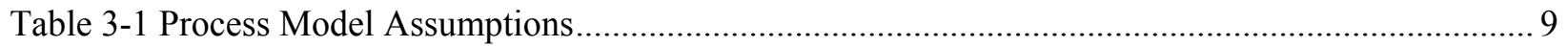

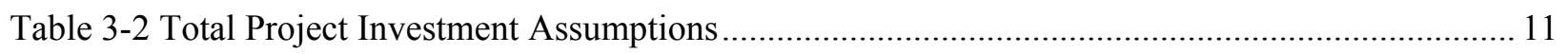

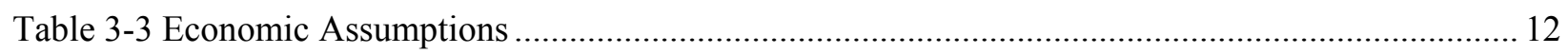

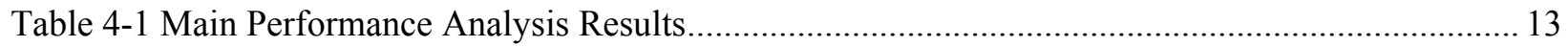

Table 4-2 Capital Costs for the MSW and Biomass Cases................................................................. 14

Table 4-3 Economic Results for the MSW and Biomass Cases .......................................................... 15

Table 4-4 MSW Conservative and MSW Goal Cases Comparison....................................................... 19

Table A-1 Stream Results for the Biomass Reference Case .................................................................... 29

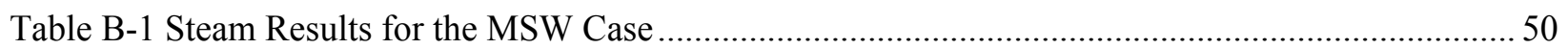




\subsection{Introduction}

Biomass is a renewable domestic resource that has the potential to make a significant impact on domestic fuel supplies. However, due to the disperse nature of biomass, its cost rises with the quantity collected. Thus capital cost economies of scale can be difficult to achieve. Municipal solid waste (MSW) is an important biomass containing resource that remains largely untapped in the United States. Some landfills have installed landfill gas recovery systems or employ waste-to-energy via combustion and/or refuse derived fuel production. However, these uses represent only a portion of the nation's waste and generally have low efficiency. Using MSW as a fuel feedstock takes advantage of existing collection infrastructure and extends landfill life. In some locations using this feedstock could take advantage of existing sorting infrastructure (i.e., Material Recover Facilities or MRFs), thus reducing costs. It also provides a domestic source of feedstock for fuel and captures energy value that is otherwise literally buried. Importantly, it does not compete for food or cultivatable land and may be available for low or even negative fees. According to the Energy Information Agency, on average, fifty-six percent of MSW can be classified as biogenic and therefore can be considered partially renewable (EIA 2007).

This report analyzes the use of MSW to produce mixed alcohols via gasification using existing technologies and compares those results to a biomass based system. The MSW plant is assumed to be colocated with a landfill. Sensitivities to fees, return on investment, and technology improvements are discussed. The process model and cost models used in this work are based upon previous analysis (Aden 2005, Phillips 2007, Zhu 2009) and employs similar methodology. 


\subsection{Process Design Basis and Modeling}

A simplified block diagram for the MSW to ethanol process is shown in Figure 2-1. In this system, MSW is first separated to remove recyclables and shredded and milled to reduce its size. It is then dried prior to gasification to synthesis gas. Then syngas is sent to a tar reformer and a scrubber. Syngas free of tars and particulates is sent to a sulfur removal unit to remove sulfur compounds. Then clean syngas is sent to a steam reformer to convert methane to hydrogen and carbon monoxide and to adjust the $\mathrm{H}_{2} / \mathrm{CO}$ ratio to that required by the mixed alcohols synthesis. The syngas is then compressed and sent to mixed alcohol synthesis. The product stream is cooled and the unconverted syngas and gaseous products are separated from the product liquid. The liquid product is dried in a molecular sieve and fractioned into ethanol and higher alcohols. Steam generated in the processes is collected and sent to the steam cycle for power generation. Process steam is extracted from the turbines for use in the gasifier, steam reformer and various process heaters. The entire process is assumed to be co-located with a landfill of suitable size. The reference biomass based process is the same as the MSW process, without the physical separation step.

The base case assumes existing technology for the gas cleanup section (tar cracking and steam reforming) and the mixed alcohols production (Spath 2005, Aden 2005, Zhu 2009). The future 2012 goal case (Phillips 2007) gas cleanup and alcohol production are included as sensitivity.

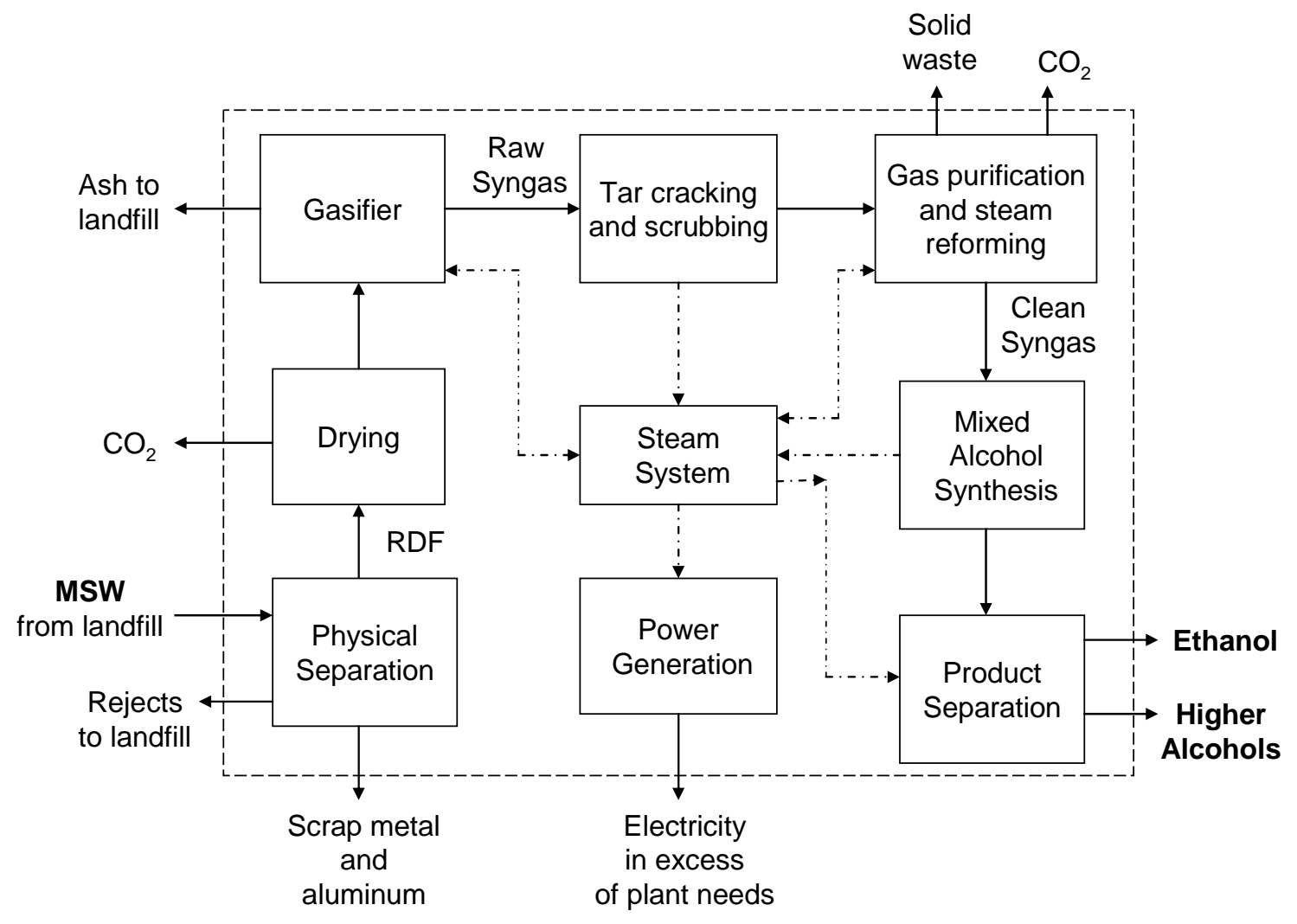

Figure 2-1 Process Diagram of the MSW to Ethanol Process 


\subsection{Process Design Basis}

The gasifier feed rate is assumed to be 2000 metric tones/day of dry feed ( 2205 short tons per day). The MSW to ethanol process consists of nine main areas. Each area is described in the follow paragraphs.

\subsubsection{Physical Separation}

Raw MSW contains a large amount of non-combustible material, and therefore requires pre-processing before sending it to a gasifier. The pre-processing must be able to meet the requirements of the gasifier and be flexible enough to handle MSW variability. This flexibility must be in terms of the type of material handled and its frequency of delivery.

The pre-processing area is assumed to be similar to a Refuse Derived Fuel (RDF) facility. Some recyclables and non-combustibles are removed from the MSW to make a higher heating value product that is sized appropriately for gasification. The RDF separation equipment is located in an enclosed area. The building contains front end loaders, stockpiling areas, cranes, shredders, a ferrous magnet to remove scrap iron, an eddy current separator to capture aluminum, screens to separate by size, air classifiers to separate by weight, a series of conveyor belts and product storage areas. A simplified block diagram is shown in Figure 2-2.

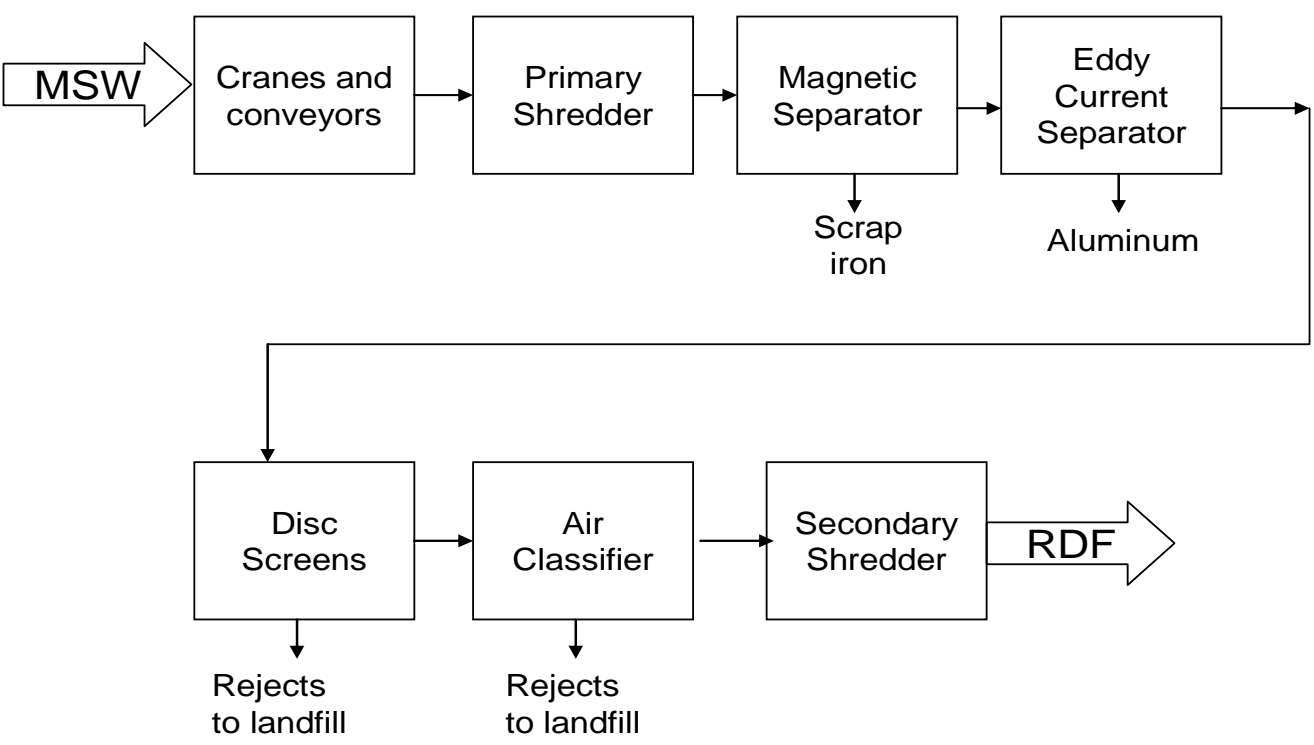

Figure 2-2 Process Diagram of the MSW to Ethanol Process 
Reject material contains broken glass, dirt and material too small to collect for the gasifier as well as some combustible material. Reject material plus recovered scrap metal is assumed to be $20 \%$ of the MSW feed rate. The rejects are returned to the landfill, while the scrap metal is stockpiled for sale. The RDF material retains significant mineral matter, resulting greater than $10 \%$ ash content.

The RDF facility is expected to operate on a schedule similar to that of the waste collection. For large municipalities, this could mean a twenty-four hour, seven days per week operation. Smaller facilities may only collect waste five days per week. Since the gasifier operates continuously at a feed rate of 2205 dry short tons per day (TPD), the RDF facility must run at a higher rate if it operates at less than round the clock. Table 2-1 shows the MSW feed rates required for various combinations of shifts per day and loss to meet 2205 dry short tons per day of RDF on a continuous basis. The term "loss" refers to the recovered metals and the reject material in the MSW that is not recovered in the RDF and is sold as scrap metal or returned to the landfill. It is assumed that the RDF facility in this study operates six days per week on two eight hour shifts per day at 20\% loss, thus requiring an MSW feed rate of 200 short tons per hour (TPH). Two trains of 100 TPH MSW will allow flexibility to handle variations in MSW rates and equipment maintenance.

Table 2-1 Example Operating Schedules for RDF Production

\begin{tabular}{|c|c|c|c|c|c|c|c|c|c|}
\hline \multirow{2}{*}{$\begin{array}{c}\text { MSW } \\
\text { Tons/hr }\end{array}$} & \multirow{2}{*}{$\begin{array}{l}\text { Shifts } \\
\text { /day }\end{array}$} & \multirow{2}{*}{$\begin{array}{l}\text { Hours } \\
\text { /shift }\end{array}$} & \multirow{2}{*}{$\begin{array}{c}\text { MSW } \\
\text { Tons } \\
\text { /day } \\
\end{array}$} & \multirow{2}{*}{$\begin{array}{c}\text { Operating } \\
\text { days } \\
\text { /week }\end{array}$} & \multirow{2}{*}{$\begin{array}{c}\text { MSW } \\
\text { Tons } \\
\text { /week } \\
\end{array}$} & \multirow{2}{*}{$\begin{array}{l}\text { MSW TPD } \\
\text { continuous }\end{array}$} & \multicolumn{3}{|c|}{$\begin{array}{c}\text { MSW conversion to } \\
\text { RDF }\end{array}$} \\
\hline & & & & & & & $75 \%$ & $80 \%$ & $85 \%$ \\
\hline 143 & 3 & 8 & 3432 & 6 & 20,592 & 2942 & 2206 & 2353 & 2500 \\
\hline 134 & 3 & 8 & 3216 & 6 & 19,296 & 2757 & 2067 & 2205 & 2343 \\
\hline 126 & 3 & 8 & 3024 & 6 & 18,144 & 2592 & 1944 & 2074 & 2203 \\
\hline 214 & 2 & 8 & 3424 & 6 & 20,544 & 2935 & 2201 & 2348 & 2495 \\
\hline 201 & 2 & 8 & 3216 & 6 & 19,296 & 2757 & 2067 & 2205 & 2343 \\
\hline 189 & 2 & 8 & 3024 & 6 & 18,144 & 2592 & 1944 & 2074 & 2203 \\
\hline 429 & 1 & 8 & 3432 & 6 & 20,592 & 2942 & 2206 & 2353 & 2500 \\
\hline 402 & 1 & 8 & 3216 & 6 & 19,296 & 2757 & 2067 & 2205 & 2343 \\
\hline 378 & 1 & 8 & 3024 & 6 & 18,144 & 2592 & 1944 & 2074 & 2203 \\
\hline
\end{tabular}

\subsubsection{Drying}

The feedstock (either RDF or biomass) at a moisture content of $50 \mathrm{wt} \%$ is fed at a rate of 2205 dry TPD. The biomass is assumed to be delivered at the correct size for gasification. The wet feed is dried in rotary dryers to a moisture content of $12 \mathrm{wt} \%$. The dried feed is then conveyed to the gasifier.

\subsubsection{Gasification}

The indirectly-heated gasifier contains both a gasifier and a combustor. Dried feedstock is fed into a lowpressure indirectly heated gasifier. Steam extracted from the steam cycle is sent to the gasifier to fluidize the bed and to supply a portion of the heat required for the gasifier. The gasifier is mainly heated by circulating olivine particles between the gasifier and the separate combustor. Char and ash formed in the gasifier is carried out of the gasifier along with the olivine, separated in a series of cyclones and sent to the fluidized bed combustor, where air is used to burn the char, thereby reheating the olivine. The heat balance in the gasifier is achieved by adjusting air to the combustor, and the olivine circulation rate. 
The indirectly-heated gasifier is modeled using the correlations reported in Spath, et al. (2005). The correlations are based on data from the Battelle-Columbus Laboratory (BCL) process development unit (PDU) gasifier. The RDF data are from the BCL PDU running on RDF as reported in Paisley, et al. (1990). These data are summarized in Table 2-2. Economics for both RDF and Biomass are included in this report.

Table 2-2 RDF and Biomass Feedstock Quality and Gasifier Conditions

\begin{tabular}{|c|c|c|}
\hline & RDF & Biomass (Poplar) \\
\hline \multicolumn{3}{|l|}{ Feedstock analysis, \% dry basis } \\
\hline volatile matter & 79.6 & 83.8 \\
\hline fixed carbon & 10.0 & 15.3 \\
\hline ash & 10.5 & 0.92 \\
\hline carbon & 45.5 & 51.0 \\
\hline hydrogen & 5.8 & 6.1 \\
\hline nitrogen & 0.3 & 0.2 \\
\hline sulfur & 0.2 & 0.1 \\
\hline oxygen (by difference) & 37.8 & 42.3 \\
\hline BTU/lb, dry basis & 7621 & 8671 \\
\hline Moisture Content, \% wet & $50 \%$ & $50 \%$ \\
\hline Gasifier temp, ${ }^{\circ} \mathrm{C}\left({ }^{\circ} \mathrm{F}\right)$ & $822(1511)$ & $870(1598)$ \\
\hline Feed moisture, $\%$ & 12 & 12 \\
\hline Gasifier press, psig & 8 & 8 \\
\hline Steam rate, $\mathrm{lb} / \mathrm{lb}$ dry feedstock & 0.398 & 0.398 \\
\hline Combustor temp, ${ }^{\circ} \mathrm{C}\left({ }^{\circ} \mathrm{F}\right)$ & $943(1730)$ & $995(1823)$ \\
\hline Combustor press, psig & 8 & 8 \\
\hline \multicolumn{3}{|l|}{ Dry syngas composition, vol\% } \\
\hline hydrogen & 17.6 & 24.0 \\
\hline carbon monoxide & 38.8 & 42.4 \\
\hline carbon dioxide & 9.3 & 12.8 \\
\hline methane & 15.6 & 15.4 \\
\hline ethane & 1.0 & 0.3 \\
\hline ethylene & 16.7 & 4.4 \\
\hline acetylene & 0.4 & 0.4 \\
\hline benzene & 0.3 & 0.1 \\
\hline naphthalene & 0.5 & 0.2 \\
\hline $\mathrm{H}_{2} / \mathrm{CO}$ ratio & 0.45 & 0.57 \\
\hline Product gas HHV, btu/scf (dry) & 663 & 468 \\
\hline
\end{tabular}

Note the higher ash content and lower heating value of RDF as compared to the wood. The ash from the RDF gasifier is assumed to be non-hazardous, but will likely require testing in the same way that ash from MSW incineration must be tested. Non-hazardous ash from incinerators can be returned to the landfill or used in roads and parking lots, depending upon local restrictions. (EPA 2008) However, some states 
regulate ash based on scale. For example, Washington State requires ash deposition to an ash monofill by plants processing more than 12 TPD of MSW (WAC 173-306-200).

\subsubsection{Tar reforming and gas scrubbing}

During gasification, a relatively small fraction of the feedstock is converted into tars consisting mostly of aromatic and poly-aromatic type hydrocarbons. The raw gas from the cyclone in the gasifier section is sent to a catalytic tar cracker, which is assumed to be a bubbling fluidized bed reactor. A portion of the tar, methane, and other light hydrocarbons in the raw gas are converted to $\mathrm{CO}$ and $\mathrm{H}_{2}$. The gasifier also produces a small amount of $\mathrm{NH}_{3}$ from the nitrogen in the biomass, which is then converted in the tar cracker to $\mathrm{N}_{2}$ and $\mathrm{H}_{2}$. The conversion percentage for each compound is reported in Spath, et al., (2005) and represents the state of technology. The gas enters the tar reformer at the gasifier outlet temperature and exits the reformer at $751^{\circ} \mathrm{C}\left(1,383^{\circ} \mathrm{F}\right)$. The syngas is further cooled to $150^{\circ} \mathrm{C}\left(300^{\circ} \mathrm{F}\right)$ and sent to a wet scrubber to remove other impurities, such as particulates, $\mathrm{NH}_{3}$, and some residual tars.

RDF is expected to contain variable amounts of chlorides depending upon the amount of plastics such as polyvinyl chloride in the MSW stream. Halides are assumed to be removed in the particulate scrubber by the addition of lime.

\subsubsection{Gas purification and steam reforming}

The scrubbed syngas is compressed to 450 psia in preparation for gas purification. Mercury and sulfur are the main contaminants that must be removed prior to stream reforming.

The RDF material potentially contains mercury which becomes volatile in the gasifier (Parsons 2002). Mercury in MSW mainly comes from fluorescent bulbs and its concentration can be as high $6000 \mathrm{ppb}$ (EPA 1997). Carbon beds are an effective means of mercury removal from syngas (Parsons 2002) and a series of fixed bed carbon vessels are assumed. The spent carbon containing adsorbed mercury is disposed of as hazardous waste.

A liquid phase oxidation (LO-CAT) process followed by a $\mathrm{ZnO}$ bed is used to remove sulfur. The LOCAT process is assumed to remove the sulfur to a concentration of $10 \mathrm{ppm} \mathrm{H}_{2} \mathrm{~S}$, and then the $\mathrm{ZnO}$ bed polishes the syngas to less than 1 ppmv (Spath, et al. 2005).

Syngas leaving the $\mathrm{ZnO}$ bed is sent to a steam reformer to convert the remaining methane and light hydrocarbons to additional syngas and to adjust the $\mathrm{H}_{2}: \mathrm{CO}$ ratio via the water-gas shift reaction. The main steam reforming reactions are:

$$
\begin{gathered}
\mathrm{C}_{\mathrm{n}} \mathrm{H}_{\mathrm{m}}+\mathrm{nH}_{2} \mathrm{O} \leftrightarrow(\mathrm{n}+\mathrm{m} / 2) \mathrm{H}_{2}+\mathrm{nCO} \\
\mathrm{CO}+\mathrm{H}_{2} \mathrm{O} \leftrightarrow \mathrm{CO}_{2}+\mathrm{H}_{2}
\end{gathered}
$$

Before the syngas is sent to the steam reformer, it is mixed with high temperature steam and compressed carbon dioxide (from the amine system as discussed below). Reactions take place between 800 and $900^{\circ} \mathrm{C}$ 
( 1472 and $1652^{\circ} \mathrm{F}$ ). The $\mathrm{H}_{2}$ : $\mathrm{CO}$ ratio is adjusted to approximately 1.2 , as required by the mixed alcohol synthesis reaction. The converted syngas passes through several heat exchangers to recover heat by generating saturate high pressure steam and superheated high pressure steam. The cooled syngas from reforming process is further cooled by air cooling and cooling water. The cooled syngas is further sent to an amine unit to remove most of the $\mathrm{CO}_{2}$ which is a diluent in the high pressure synthesis system. The clean syngas is compressed to $2000 \mathrm{psi}$ and sent to the mixed alcohol synthesis section. The steam reformer is fired with off-gas from the mixed alcohol synthesis.

\subsubsection{Mixed alcohol synthesis}

The mixed alcohol synthesis involves multiple reactions with different pathways to various alcohols and hydrocarbons. The overall stoichiometric reaction for higher alcohol synthesis is:

$$
\mathrm{nCO}+2 \mathrm{nH}_{2} \rightarrow \mathrm{C}_{\mathrm{n}} \mathrm{H}_{2 \mathrm{n}+1} \mathrm{OH}+(\mathrm{n}-1) \mathrm{H}_{2} \mathrm{O}
$$

where the value of "n" typically ranges from 1 to 6 . Hydrocarbon synthesis takes place according to a similar reaction scheme. While the stoichiometry of these reactions suggests an optimum $\mathrm{H}_{2} / \mathrm{CO}$ ratio approximately 2 , the optimal ratio is closer to 1.0 if the catalyst is significantly active for the water-gas shift reaction. This study assumes a modified Fischer-Tropsch catalyst $(\mathrm{K} / \mathrm{Co} / \mathrm{MoS}$ catalyst) that reflects the current state of technology, and thus represents a scenario that might be obtainable today. A description of this catalyst can be found in Aden et al, (2005).

Clean syngas at $2000 \mathrm{psi}$ is preheated to $299^{\circ} \mathrm{C}\left(570^{\circ} \mathrm{F}\right)$ in a feed-product exchanger. The mixed alcohol reactor is assumed to be of a fixed bed tubular design, with catalyst in the tubes and steam raised in the shell. The product gas is partially cooled against the inlet compressed syngas, followed by further cooling to condense the alcohols and water. Most of unconverted syngas is recycled to the stream reformer. The methanol product is recycled back to the mixed alcohol synthesis reactor to increase the conversion efficiency. The liquid alcohols are then sent to the alcohol separation and purification processes. Methanol purge and product gas purge streams are combined and sent to the fuel gas system. The assumed mixed alcohol synthesis reaction conditions and per pass conversions for are shown in Table 2-3. The specific conversions of $\mathrm{CO}$ in each of the main reactions are set in order to reach catalyst performance targets consistent with those of Aden, et al. (2005). 
Table 2-3 Mixed Alcohol Synthesis Assumptions

\begin{tabular}{|c|c|}
\hline Parameter & Values \\
\hline Temperature $\left({ }^{\circ} \mathrm{F}\right)$ & 570 \\
\hline Pressure (psia) & 2000 \\
\hline $\mathrm{H}_{2} / \mathrm{CO}$ Ratio & 1.2 \\
\hline $\mathrm{CO}_{2}$ inlet concentration & $0.2 \mathrm{~mol} \%$ \\
\hline Gas hourly space velocity, v/h/v & 3000 \\
\hline $\mathrm{CO}+\mathrm{H}_{2}$ Reactions & Mole \% CO Conversion per pass \\
\hline $\mathrm{CO}+\mathrm{H}_{2} \mathrm{O} \rightarrow \mathrm{CO}_{2}+\mathrm{H}_{2}$ & $13 \%$ \\
\hline $\mathrm{CO}+3 \mathrm{H}_{2} \rightarrow \mathrm{CH}_{4}+\mathrm{H}_{2} \mathrm{O}$ & $4.5 \%$ \\
\hline $2 \mathrm{CO}+4 \mathrm{H}_{2} \rightarrow \mathrm{C}_{2} \mathrm{H}_{6}+\mathrm{H}_{2} \mathrm{O}$ & $0.5 \%$ \\
\hline $\mathrm{CO}+\mathrm{H}_{2} \rightarrow$ Methanol & $4.1 \%$ \\
\hline $2 \mathrm{CO}+4 \mathrm{H}_{2} \rightarrow$ Ethanol $+\mathrm{H}_{2} \mathrm{O}$ & $11.4 \%$ \\
\hline $3 \mathrm{CO}+6 \mathrm{H}_{2} \rightarrow$ Propanol $+2 \mathrm{H}_{2} \mathrm{O}$ & $3 \%$ \\
\hline $4 \mathrm{CO}+8 \mathrm{H}_{2} \rightarrow$ n-Butanol $+3 \mathrm{H}_{2} \mathrm{O}$ & $1 \%$ \\
\hline $5 \mathrm{CO}+10 \mathrm{H}_{2} \rightarrow$ n-Pentanol $+4 \mathrm{H}_{2} \mathrm{O}$ & $0.5 \%$ \\
\hline Methanol Recycle Reactions & Mole \% Recycled Methanol Conversion \\
\hline Methanol $+\mathrm{CO}+2 \mathrm{H}_{2} \rightarrow$ Ethanol $+\mathrm{H}_{2} \mathrm{O}$ & $58 \%$ \\
\hline Methanol $+2 \mathrm{CO}+4 \mathrm{H}_{2} \rightarrow$ Propanol $+2 \mathrm{H}_{2} \mathrm{O}$ & $7 \%$ \\
\hline Methanol $+3 \mathrm{CO}+6 \mathrm{H}_{2} \rightarrow$ n-Butanol $+3 \mathrm{H}_{2} \mathrm{O}$ & $4.5 \%$ \\
\hline Methanol $+4 \mathrm{CO}+8 \mathrm{H}_{2} \rightarrow$ n-Pentanol $+4 \mathrm{H}_{2} \mathrm{O}$ & $2 \%$ \\
\hline
\end{tabular}

The large heat release from the exothermic mixed alcohol reactor is removed by vaporizing boiler feed water on the shell side of the reactor. The high pressure steam is sent to the steam cycle and power recovery section for electric power generation.

\subsubsection{Product separation and purification}

The raw mixed alcohol product from the synthesis step is dried with a molecular sieve. The dried product is then distilled into a methanol stream that is recycled to the synthesis reactor, a purified ethanol stream and a higher alcohol stream. The higher alcohol product contains propanol and higher boiling alcohols.

\subsubsection{Power generation}

Saturated steam is generated by cooling the process streams in the gasifier, steam reformer and mixed alcohol synthesis areas. Saturated steam is superheated in the steam reformer section then sent to a steam turbine to generate power for the plant and to provide process steam for use in the system.

\subsection{Analysis Approach}

The process simulation was developed in CHEMCAD and the capital and operating costs were assembled in an EXCEL spreadsheet. A discounted cash flow analysis is used to estimate the ethanol selling price. 


\subsection{Simulation and Economic Assumptions}

The main assumptions for the performance and cost models are described in this section.

\subsection{Simulation Assumptions}

Table 3-1 shows the main assumptions for the biomass and MSW simulations. The main difference is in the composition of the feedstocks.

Table 3-1 Process Model Assumptions

\begin{tabular}{|c|c|c|}
\hline Parameter & Biomass Case & MSW Case \\
\hline$\% \mathrm{MSW}$ in RDF & Not applicable & $80 \%$ \\
\hline \multicolumn{3}{|l|}{ Dryer } \\
\hline Feed inlet moisture, wt $\%$ & 50 & 50 \\
\hline Outlet moisture, wt $\%$ & 12 & 12 \\
\hline \multicolumn{3}{|l|}{ Gasifier } \\
\hline Pressure, psi & 23 & 23 \\
\hline Temperature, ${ }^{\circ} \mathrm{C}\left({ }^{\circ} \mathrm{F}\right)$ & $822(1511)$ & $870(1598)$ \\
\hline Bone dry feed, metric ton/d & 2000 & 2000 \\
\hline Tar Reformer, $\mathbf{T},{ }^{\circ} \mathrm{C}\left({ }^{\circ} \mathrm{F}\right) / \mathbf{P}$, psi & $751(1383) / 23$ & $751(1383) / 23$ \\
\hline \multicolumn{3}{|l|}{ Steam Reforming } \\
\hline Temperature, ${ }^{\circ} \mathrm{C}\left({ }^{\circ} \mathrm{F}\right)$ & $900(1652)$ & $900(1652)$ \\
\hline Pressure, psia & 435 & 435 \\
\hline $\mathrm{H}_{2}: \mathrm{CO}$ in reformed syngas & 2.1 & 2.1 \\
\hline \multicolumn{3}{|l|}{$\begin{array}{l}\text { Mixed alcohol Synthesis and } \\
\text { Purification }\end{array}$} \\
\hline Temperature, ${ }^{\circ} \mathrm{C}\left({ }^{\circ} \mathrm{F}\right)$ & $299(570)$ & $299(570)$ \\
\hline Pressure, psia & 2000 & 2000 \\
\hline Methanol Recycle, \% & 90 & 90 \\
\hline \multicolumn{3}{|l|}{ Steam System } \\
\hline Pressure, psia & 800 & 800 \\
\hline Superheat temperature, ${ }^{\circ} \mathrm{C}\left({ }^{\circ} \mathrm{F}\right)$ & $538(1000)$ & $538(1000)$ \\
\hline
\end{tabular}




\subsection{Economic Assumptions}

Figure 3-1 plots the total capital investment required for an RDF facility as taken from various literature sources (source dates are listed in the legend) and converted to January 2008 dollars using the Chemical Engineering Index (CEI 2008). Included in each sources estimate are all direct and indirect capital costs to provide sufficient equipment to produce RDF from MSW and recover recyclables. The estimates also include scales, a processing building and all site work. Note that the trend of the capital investment increase is almost linear with the increase in plant scale. RDF facilities typically have multiple lines to accommodate equipment maintenance and variable processing rates and therefore have little economy of scale.

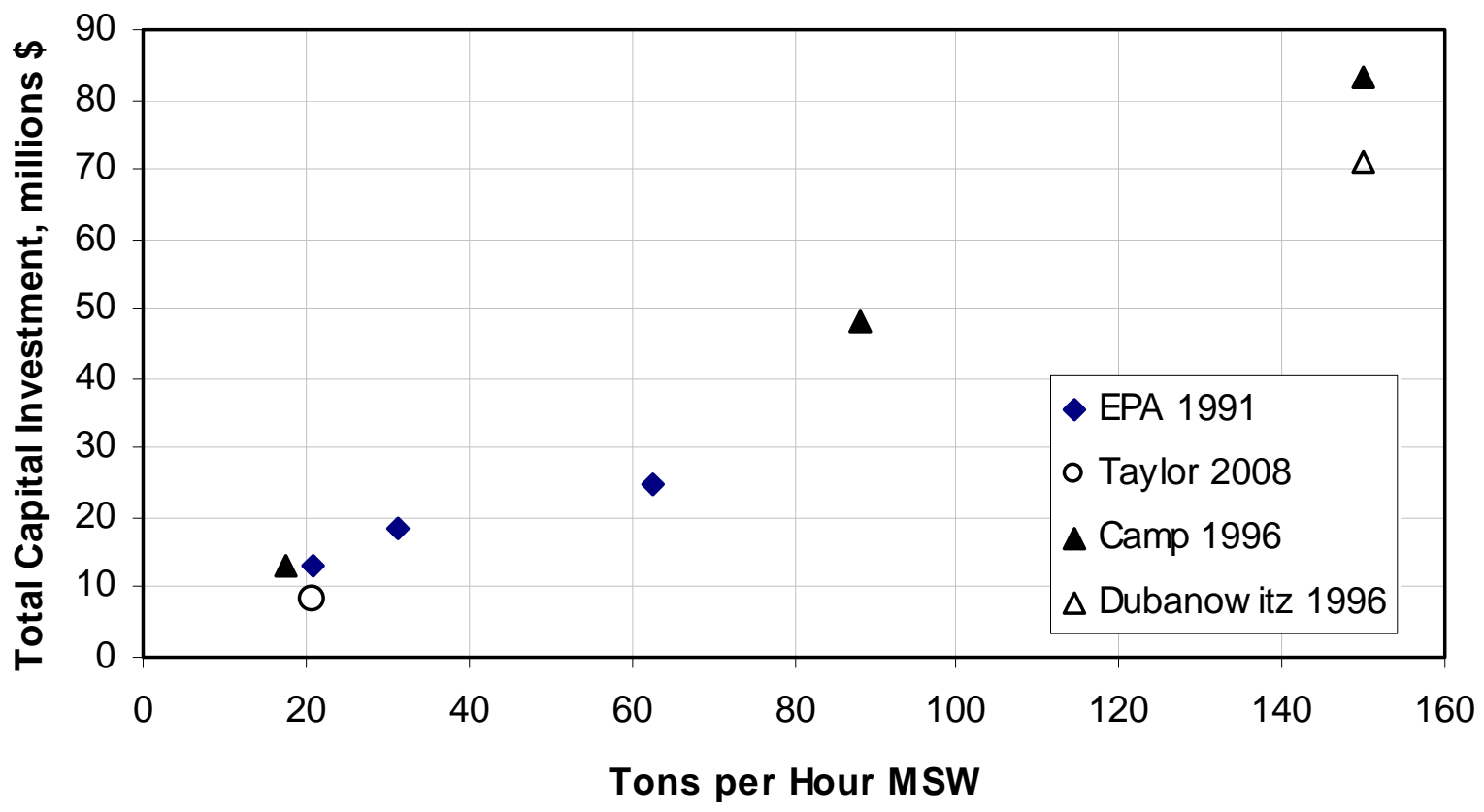

Figure 3-1 RDF Facility Scale vs. Total Capital Investment

The capital investment for the rest of the mixed alcohols plant is determined from a cost rollup of the specific equipment needed for each area of the plant (e.g. dryer, gasifier, heat recovery, mixed alcohol reactor). Most of the base equipment costs for the gas purification and conditioning and the steam cycle and power generation sections of the plant come from Spath, et al. (2005). The estimation of the equipment costs for the indirectly heated gasifier is based on Hamelinck and Faaij (2002). The equipment costs for mercury removal is from Parsons (2002). The mixed alcohol synthesis and product separation equipment is sized using the heat and material balances, and the associated equipment costs come from APSEN ICARUS.

All capital costs are reported in January 2008 dollars. The total capital investment for the mixed alcohol plant excluding the RDF facility is factored from installed equipment costs using the factors shown in Table 3-2. The capital investment for the RDF facility is added to the capital investment for the remainder of the plant to determine the total capital required. 
Table 3-2 Total Project Investment Assumptions

\begin{tabular}{|l|c|}
\hline $\begin{array}{c}\text { Total Purchased Equipment Cost for Mixed } \\
\text { Alcohols Portion of the Plant (TPEC) }\end{array}$ & $100 \%$ of TPEC \\
\hline Purchased Equipment Installation & $39 \%$ \\
\hline Instrumentation and Controls & $26 \%$ \\
\hline Piping & $31 \%$ \\
\hline Electrical Systems & $10 \%$ \\
\hline Buildings (including services) & $29 \%$ \\
\hline Yard Improvements & $12 \%$ \\
\hline Total Installed Cost (TIC) & $247 \%$ \\
\hline Indirect Costs & $32 \%$ \\
\hline Engineering & $34 \%$ \\
\hline Construction & $23 \%$ \\
\hline Legal and Contractors Fees & $37 \%$ \\
\hline Project Contingency & $126 \%$ \\
\hline Total Indirect & $373 \%$ \\
\hline $\begin{array}{l}\text { Capital Investment for the Mixed Alcohols } \\
\text { Portion of the Plant }\end{array}$ & \\
\hline
\end{tabular}

Table 3-3 lists the assumptions used to estimate the production costs. The minimum ethanol selling price (MESP) was determined using a discounted cash flow rate of return analysis similar to that used in Phillips et al. 2007. The MESP is the selling price of the fuel that makes the net present value of the process equal to zero for a specified discounted cash flow rate of return over a 20 year plant life. A sensitivity analysis was conducted to determine the effect of different financial and operating assumptions on the MESP. 
Table 3-3 Economic Assumptions

\begin{tabular}{|c|c|c|c|}
\hline & $\begin{array}{l}\text { Value used } \\
\text { in model, } \\
2008 \text { basis }\end{array}$ & Units or Basis & Reference \\
\hline \multicolumn{4}{|l|}{ Raw Materials } \\
\hline Hybrid poplar chips & 60 & \$/dry short ton & Aden, 2008 \\
\hline Olivine makeup & 207 & $\$ /$ short ton & Phillips, et al. 2007* \\
\hline Ash disposal & 34 & $\$ /$ short ton & Valkenburg, et al. 2008 \\
\hline Tar cracker catalyst & 6.15 & $\$ / 1 \mathrm{~b}$ & Phillips, et al., 2007* \\
\hline Reformer catalyst & 21.9 & $\$ / 1 b$ & SRI PEP 2007* \\
\hline Mixed alcohol catalyst & 5.25 & $\$ / l b$ & Phillips, et al. 2007 \\
\hline Carbon & 8.34 & $\$ / 1 b$ & Parsons, 2002* \\
\hline \multicolumn{4}{|l|}{ By-Products } \\
\hline Scrap metal & 0.2 & $\$ / 1 b$ & USFN 2008 \\
\hline Scrap aluminum & 1.0 & $\$ / \mathrm{lb}$ & Thompson 2008 \\
\hline Higher alcohol value & 1.15 & \$/gallon & Phillips, et al. 2007 \\
\hline Sulfur & 40 & \$/ton & Phillips, et al. 2007* \\
\hline \multicolumn{4}{|l|}{ Waste By-Products } \\
\hline Waste water treatment & 2.47 & $\$ / 100 \mathrm{ft}^{3}$ & Phillips, et al. 2007* \\
\hline Hazardous waste disposal & 500 & \$/ton & Parsons, 2002 \\
\hline Non-hazardous waste disposal & 34 & $\$ /$ ton & Valkenburg, et al. 2008 \\
\hline \multicolumn{4}{|l|}{ Utilities } \\
\hline Cooling water & 168 & $\notin / 1000$ gal & Phillips, et al. 2007* \\
\hline Electricity & 6.27 & $\notin / \mathrm{kWh}$ & EIA 2008, industrial price \\
\hline Stream Factor & $90 \%$ & & estimated \\
\hline MACRS Depreciation, yrs & 7 & & Phillips, et al. 2007 \\
\hline Plant life, yrs & 20 & & Phillips, et al. 2007 \\
\hline $\begin{array}{l}\text { Construction Period } \\
1^{\text {st }} 6 \text { months expenditure } \\
\text { Next } 12 \text { months expenditure } \\
\text { Last } 12 \text { months expenditure }\end{array}$ & $\begin{array}{c}2.5 \text { years } \\
8 \% \\
60 \% \\
32 \% \\
\end{array}$ & & Phillips, et al. 2007 \\
\hline $\begin{array}{l}\text { Start-up time } \\
\text { Revenues } \\
\text { Variable Costs } \\
\text { Fixed Costs } \\
\end{array}$ & $\begin{array}{c}6 \text { months } \\
50 \% \\
75 \% \\
100 \% \\
\end{array}$ & & Phillips, et al. 2007 \\
\hline Working Capital & \multicolumn{2}{|c|}{$5 \%$ of Total Capital Investment } & Phillips, et al. 2007 \\
\hline Land & \multicolumn{2}{|c|}{$\begin{array}{l}6 \% \text { of Total Purchased Equipment } \\
\text { Cost (taken as } 1^{\text {st }} \text { year construction } \\
\text { expense) }\end{array}$} & Phillips, et al. 2007 \\
\hline Internal Rate of Return & \multicolumn{2}{|c|}{$10 \%$} & Phillips, et al. 2007 \\
\hline
\end{tabular}




\subsection{Results and Analysis}

This section describes the main performance and cost simulation results for each scenario.

\subsection{Performance Results}

Table 4-1 shows the main performance results for the MSW case and compares it to the same process fed only with biomass. Both cases produce higher alcohols and sulfur as by-products. The mixed alcohol yield is lower for the MSW case due to the higher fraction of inorganic material in the RDF than in the wood. Both processes also generate electricity in excess of the plant's needs. Additionally, the MSW based process recovers metals that can be sold as scrap. On the other hand, the MSW case produces more waste streams, although one could argue that the wastes are a fraction of the total MSW waste to begin with, and thus a net gain to the landfill in terms of landfill usage. The non-hazardous MSW waste stream consists of ash, MSW in the materials separation pre-processing area that is not recovered metals or RDF, and spent olivine. However, the spent carbon beds contain mercury and therefore must be disposed of as hazardous waste.

Table 4-1 Main Performance Analysis Results

\begin{tabular}{|c|c|c|}
\hline Case & MSW Case & Biomass Case \\
\hline \multicolumn{3}{|l|}{ Feedstock } \\
\hline Wood chips or MSW, dry million lb/y & $1930 \mathrm{MSW} ; 1,447 \mathrm{RDF}$ & 1,447 Wood chips \\
\hline \multicolumn{3}{|l|}{ Products } \\
\hline Ethanol, mmgal/y & 27 & 36 \\
\hline Propanol and high alcohols, million gal/y & 9 & 12 \\
\hline Sulfur, lb/y & 81,600 & 35,200 \\
\hline Recyclable scrap aluminum, million $\mathrm{lb} / \mathrm{y}$ & 110 & 0 \\
\hline Recyclable scrap iron, million $1 \mathrm{~b} / \mathrm{y}$ & 25 & 0 \\
\hline \multicolumn{3}{|l|}{ Yields } \\
\hline Ethanol, gal/ton dry feedstock & 28 MSW basis; 38 RDF basis & 50 \\
\hline Higher alcohols, gal/ton dry feedstock & 9 MSW basis; 13 RDF basis & 17 \\
\hline \multicolumn{3}{|l|}{ Waste Products } \\
\hline Hazardous waste, lb/y & 80,000 & 0 \\
\hline $\begin{array}{l}\text { Total Non-hazardous solid waste, million } \\
\mathrm{lb} / \mathrm{y}\end{array}$ & 390 & 22.5 \\
\hline Ash, million $\mathrm{lb} / \mathrm{y}$ & 152 & 19 \\
\hline Spent olivine, million $\mathrm{lb} / \mathrm{y}$ & 3 & 3.5 \\
\hline MSW rejects, million $1 \mathrm{~b} / \mathrm{y}$ & 235 & 0 \\
\hline Net Power for export, MW & 9.3 & 3.2 \\
\hline
\end{tabular}




\subsection{Economic Results}

Table 4-2 shows the capital cost breakdown for each section of the plant. The RDF facility amounts to almost a quarter of the required investment. Gasification and syngas cleanup make up the bulk of the rest of the costs. Improved and simplified syngas cleanup and improved mixed alcohols synthesis is an ongoing area of research. It is expected that costs for these areas will decrease with time. Reduction in capital and improved yields are addressed in the sensitivity section.

Table 4-2 Capital Costs for the MSW and Biomass Cases

\begin{tabular}{|c|c|c|c|c|}
\hline & \multicolumn{2}{|c|}{ MSW Case } & \multicolumn{2}{|c|}{ Biomass Case } \\
\hline Million gallons/year ethanol & \multicolumn{2}{|c|}{27} & \multicolumn{2}{|c|}{36} \\
\hline Capital Costs & Million \$ & $\%$ of Total & Million \$ & $\%$ of Total \\
\hline RDF production & $\$ 105$ & $23 \%$ & $\$ 0$ & \\
\hline Feedstock drying & $\$ 40$ & $9 \%$ & $\$ 39$ & $11 \%$ \\
\hline Gasification, tar reforming, scrubbing & $\$ 67$ & $15 \%$ & $\$ 56$ & $16 \%$ \\
\hline Syngas conditioning & $\$ 164$ & $37 \%$ & $\$ 167$ & $49 \%$ \\
\hline Mixed alcohol synthesis & $\$ 20$ & $4 \%$ & $\$ 21$ & $6 \%$ \\
\hline Mixed alcohol separation & $\$ 9$ & $2 \%$ & $\$ 11$ & $3 \%$ \\
\hline Steam system and power generation & $\$ 34$ & $8 \%$ & $\$ 39$ & $11 \%$ \\
\hline Remainder off-site battery limits & $\$ 9$ & $2 \%$ & $\$ 9$ & $3 \%$ \\
\hline Total Capital Investment & \multicolumn{2}{|c|}{$\$ 449$} & \multicolumn{2}{|c|}{$\$ 343$} \\
\hline Project investment/annual gallon ethanol & \multicolumn{2}{|c|}{16} & \multicolumn{2}{|c|}{9} \\
\hline
\end{tabular}

Table 4-3 shows the operating cost breakdown for both cases. The MSW case assumes that the plant is co-located with a municipal waste landfill and that the MSW feedstock is free. This case also assumes that the non-hazardous waste is returned to the landfill for no fee. The MSW case has lower variable costs than the biomass case due to no feedstock cost and additional by-product credits from the sale of the recyclables. The fixed costs for the MSW case are higher, mainly due to the larger work force needed to produce the RDF material. The gasification and mixed alcohol production areas are assumed to be highly automated and require fewer operators per unit than does the labor intensive RDF facility. Waste treatment costs are relatively low for both cases. Disposal of the mercury laden spent carbon is not a large cost factor for the MSW case. The higher capital costs for the MSW case are more than offset by the lower operating costs. The base MSW case selling price of $\$ 1.85$ per gallon of ethanol falls within the selling price of ethanol over the past year. Ethanol prices from June 2007 to October 2008 have fluctuated up and down between $\$ 1.60$ and \$2.50/gallon (ICIS 2008). However, a 10\% internal rate of return on investment may not be sufficiently high to make this economically attractive to investors. Sensitivities to return on capital are explored in the next section. 
Table 4-3 Economic Results for the MSW and Biomass Cases

\begin{tabular}{|l|c|c|}
\hline & MSW Case & Biomass Case \\
\hline Million gallons/year ethanol & 27 & 36 \\
\hline Operating Costs & \$/gal \\
\hline Raw materials & 0.00 & 1.19 \\
\hline Feedstock (MSW or Biomass) & 0.10 & 0.09 \\
\hline Catalysts \& Chemicals & \multicolumn{2}{|c|}{} \\
\hline By-product credits & -0.39 & -0.39 \\
\hline Higher alcohols & -0.86 & 0.00 \\
\hline Scrap Aluminum & -0.58 & 0.00 \\
\hline Scrap Iron & -0.17 & -0.04 \\
\hline Electricity sold to grid & \multicolumn{2}{|c|}{} \\
\hline Waste treatment or Disposal & 0.000 & 0.01 \\
\hline Gasifier ash & 0.000 & 0.00 \\
\hline MSW rejects & 0.0001 & 0.00 \\
\hline Spent carbon & 0.026 & 0.02 \\
\hline Waste water treatment & -1.86 & 0.87 \\
\hline Total variable cost, \$/gal ethanol & 0.87 & 0.51 \\
\hline Fixed costs, \$/gal ethanol & 0.82 & 0.47 \\
\hline Capital depreciation, \$/gal ethanol & 0.56 & 0.33 \\
\hline Average income tax, \$/gal ethanol & 1.46 & 0.86 \\
\hline Average return on investment (10\% IRR) & 1.85 & 3.05 \\
\hline $\begin{array}{l}\text { Estimated Selling Price (10\% IRR), \$/gal } \\
\text { ethanol }\end{array}$ & & \\
\hline
\end{tabular}

\subsection{Sensitivity Analysis}

A sensitivity analysis was conducted to investigate the effects of different cost assumptions such as return on investment, MSW fee, and by-product credits.

\subsubsection{Effect of MSW Fee and Return on Investment}

According to a 2004 survey, as reported in Valkenburg et al. 2008, tipping fees vary widely across the country, from a low of $\$ 24.06$ per ton in the south to $\$ 70.06$ per ton in the Northeast, with the average of approximately $\$ 34.29 /$ ton nationwide. Tipping fees for MSW that was incinerated averaged about $\$ 61.64$ nationwide. Thus there is precedent for increasing tipping fees to offset capital costs, assuming the local market will bear the cost increase. Figure 4-1 shows how varying the tipping fee affects the minimum ethanol selling price at a $10 \%$ IRR. 


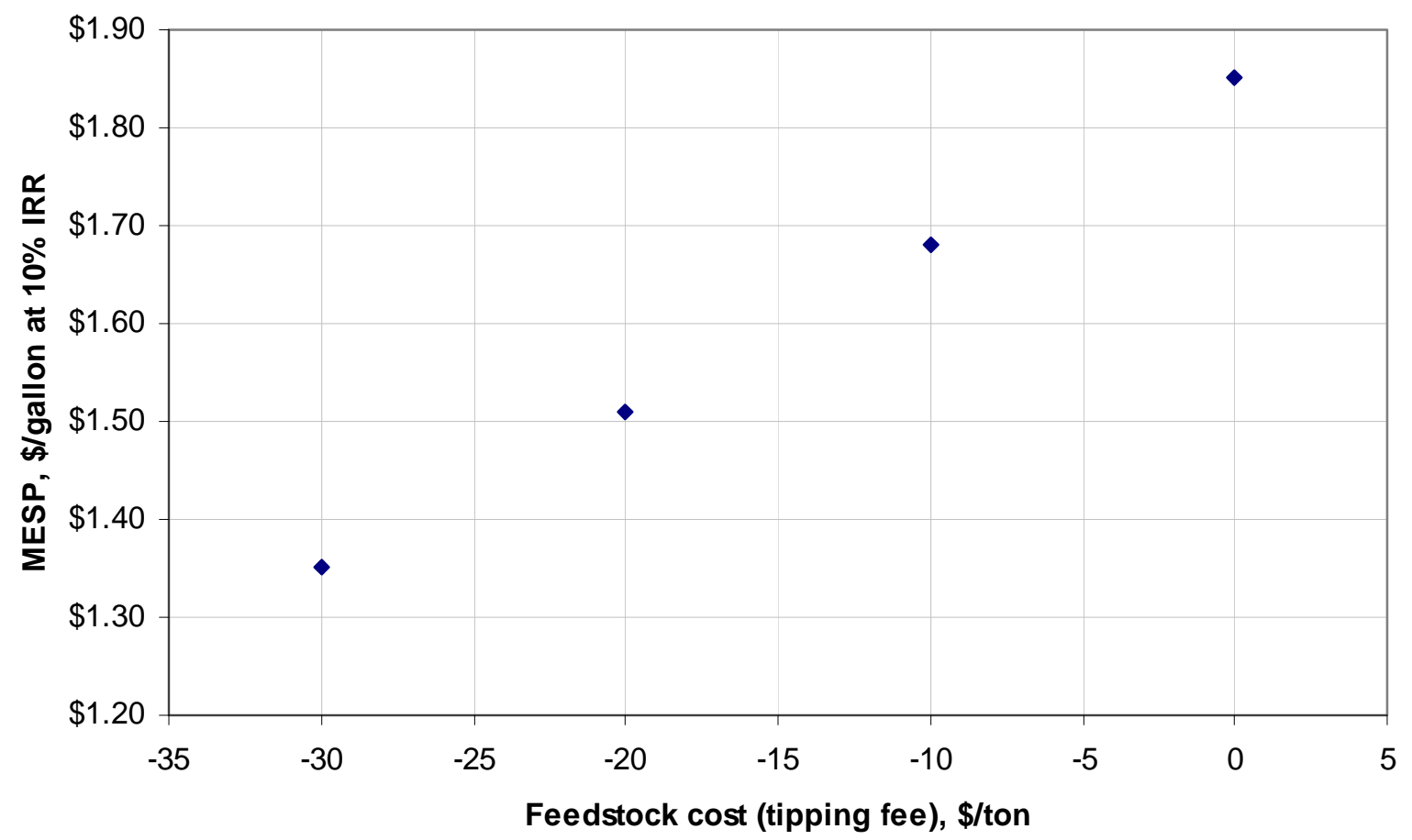

Figure 4-1 Effect of Tipping Fee on MESP

Recall that the tipping fee is the cost charged by the landfill to waste generators; a tipping fee of $\$ 30 /$ ton is the same as a feedstock cost of $-\$ 30 /$ ton. Increasing the tipping fee from $\$ 0$ to $\$ 30$ per ton is worth approximately $\$ 0.50 /$ gallon of ethanol.

Figure 4-2 expands Figure 4-1 to show the effects of increasing the return rate. This plot shows several things:

- Even with a negative feedstock cost, the MSW case can at best return about $10 \%$ of the capital before the selling price of ethanol exceeds $\$ 2.00 /$ gallon.

- As shown previously in Table 4-2, the RDF facility significantly increases the capital cost of the MSW plant compared to the biomass (wood) plant. The MSW case and the biomass (wood) case MESP overlap when the IRR is approximately $20 \%$. This is mainly due to the tradeoff between higher capital and lower feedstock cost for the MSW case as compared with the lower capital and higher feedstock costs for the biomass case. Above an IRR of $20 \%$, the higher capital costs for the MSW case offset the gains made by low or no feedstock cost.

- There do not appear to be incentives to decrease the scale of the plant from 2205TPD RDF, as this is likely to increase production costs and thus lower the return on investment. 


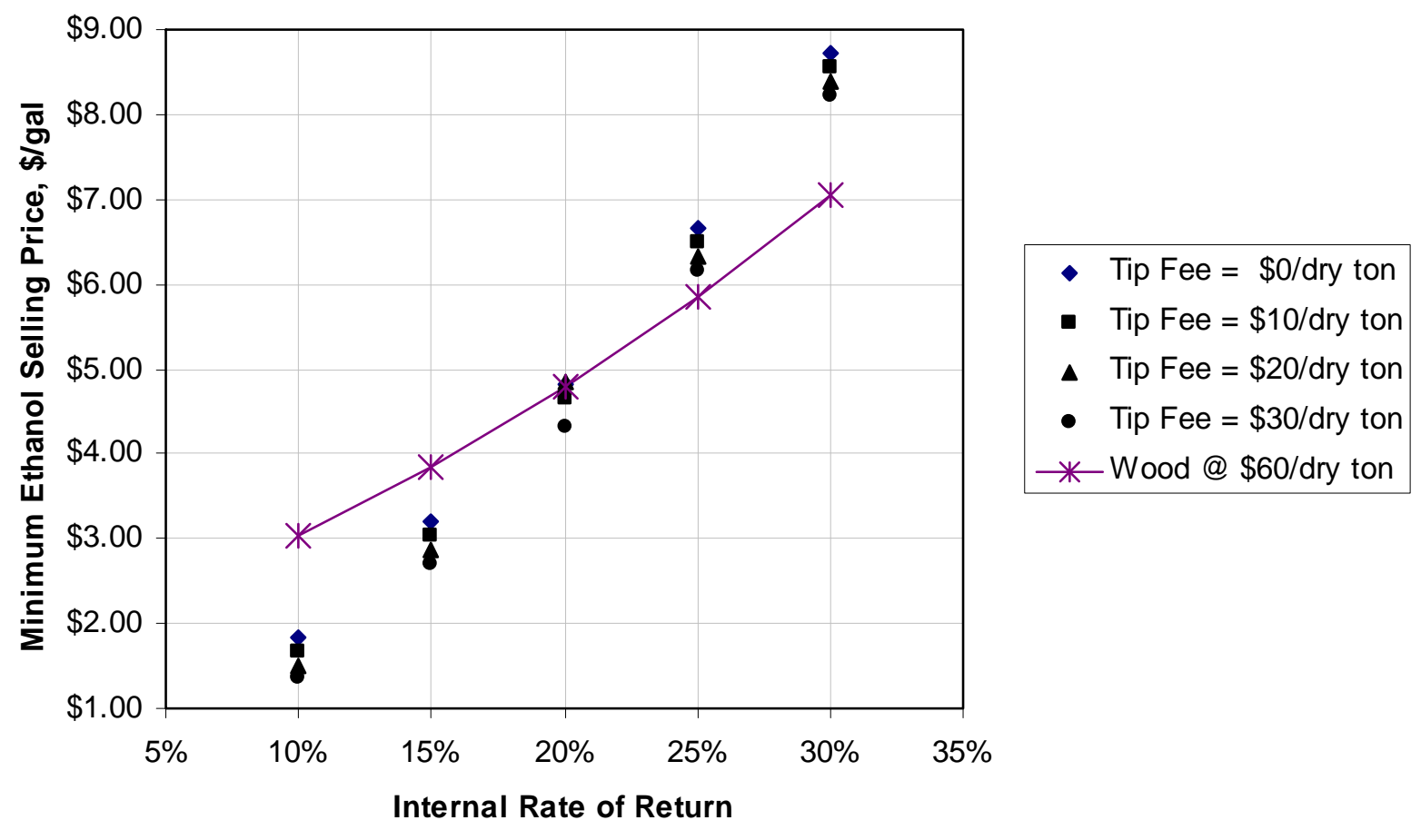

Figure 4-2 Effect of Tipping Fee on MESP at Different Rates of Return

\subsubsection{Effect of RDF Operating Schedule and MSW and By-Product Value}

Figure 4-3 shows the effect of selected operating variables. They are shown as cost differences with the base case assumptions of 2205 TPD MSW, 10\% IRR, and no cost for the MSW. The top two bars show the sensitivity to RDF processing schedules. The base case assumes that the RDF plant processes MSW on two eight-hour shifts/day for six days per week, while the gasifier and alcohol synthesis systems operate continuously. The base case also assumes that $80 \%$ of the MSW is recovered as RDF. Forty cents per gallon could be saved by continuous 24 hour per day, seven day per week RDF processing. This is mostly due to the smaller capital investment for the RDF plant. Maintaining the same operating schedule as the base case, but with only $75 \%$ recovery of MSW as RDF increases costs by about twenty cents per gallon.

The middle three bars show the effect of fees. In the base case, the MSW is assumed to be free of charge and the waste generated in the RDF plant is landfilled at no additional cost. As noted previously, mercury in the MSW is assumed to be part of the RDF and captured post gasification in a carbon bed. The carbon bed is then disposed of as hazardous waste. If the reject MSW material (glass and fines) in the RDF plant contains significant amounts of mercury, say from broken fluorescent bulbs, then that material might be re-classified as hazardous. Disposal of the MSW reject material as hazardous waste increases the ethanol selling price by over two dollars per gallon. While this may not be a likely scenario, it does illustrate the need to sample and test waste materials for proper disposal. 


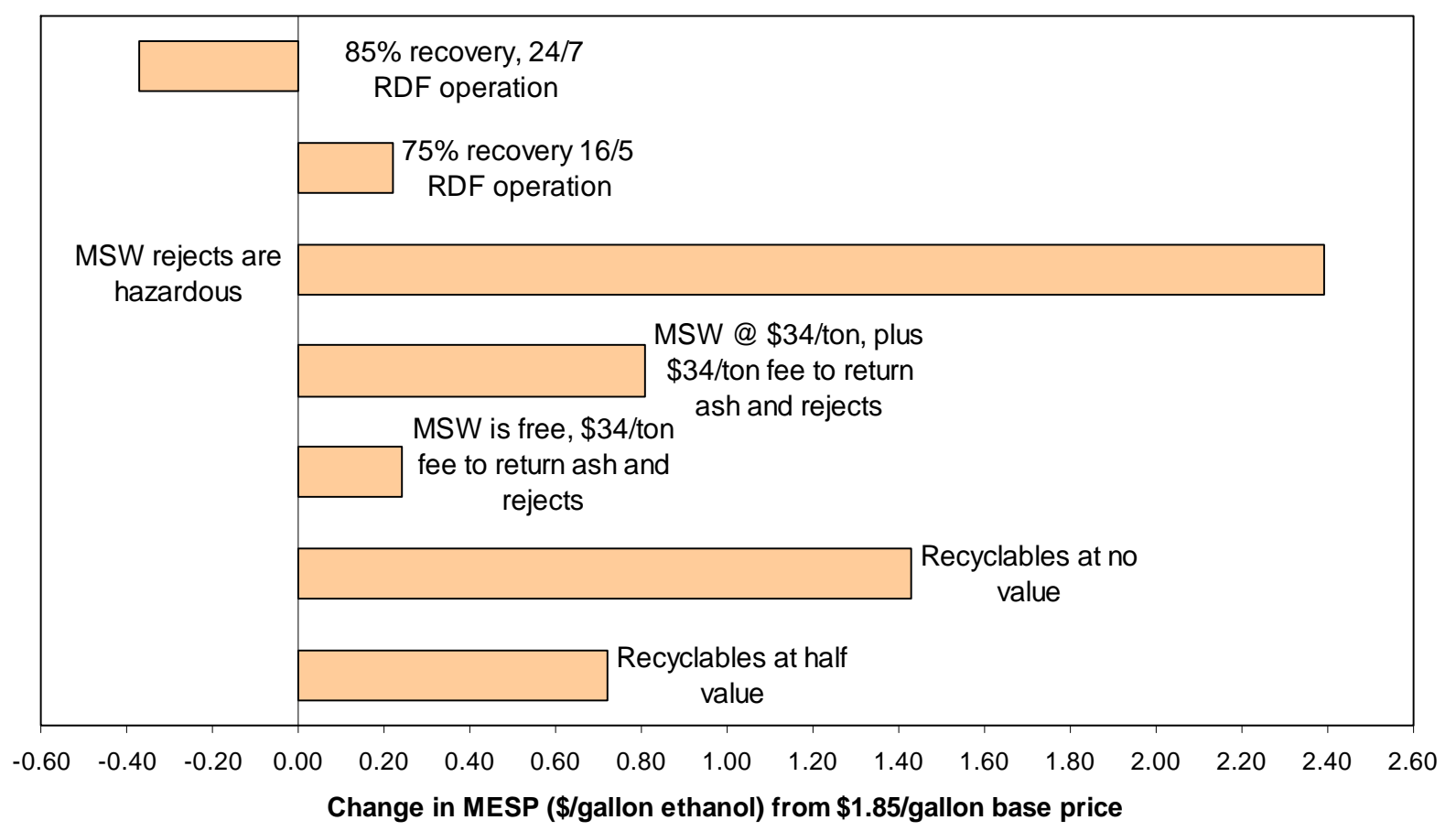

Figure 4-3 MESP Sensitivity to Process and Operating Changes

If the facility is not owned by the landfill, but still adjacent to it, then the landfill may charge a fee for providing the MSW and fees to return the rejected solids. This is just the opposite of the tipping fee case presented in the previous section. In the tipping fee case, the landfill charges the waste generators to leave the MSW, and thus the feedstock itself is potentially income generating. This time, rather than a negative cost feedstock, the mixed alcohol plant must purchase the MSW from the landfill. Assuming that $+\$ 34 /$ ton is charged for the MSW to the RDF plant and another $+\$ 34 /$ ton is charge to return the waste generated in RDF production, then the cost of ethanol rises by about $\$ 1.40 /$ gallon. If the landfill does not charge a fee for the MSW, but does require payment for ash rejects, then the selling price increases by about twenty cents per gallon (as shown in the bottom bar)

The lowest two bars show the effects of by-products on MESP. Reclaiming and selling scrap iron and aluminum (noted as recyclables on the chart) is important for process economics. Over one dollar per gallon is lost if the recyclables have no value (again assuming that the MSW is obtained at no cost to the RDF plant).

\subsubsection{Effect of Technology Improvements}

The conservative mixed alcohol case represents a scenario that might be possible to implement today. However, as shown in Figure 4-2, the economics are attractive only at about 10\% IRR. Technology improvements can help reduce the capital cost and improve the overall economics. Thus the goal case thermo-chemical mixed alcohol process as described in Phillips et al. (Phillips 2007) was analyzed assuming MSW with RDF processing. As described in that report, improvements to the tar reformer, elimination of the steam reformer, simplified syngas conditioning and improved mixed alcohol catalyst yields reduce the capital and operating costs. A comparison between the main assumption differences and 
main results for the conservative MSW case and the goal MSW case are shown in Table 4-4. Assumptions not shown are the same as those listed in Table 3-1.

Table 4-4 MSW Conservative and MSW Goal Cases Comparison

\begin{tabular}{|c|c|c|}
\hline Assumption Differences & $\begin{array}{l}\text { MSW Conservative } \\
\text { Case } \\
\end{array}$ & MSW Goal Case \\
\hline Tar Cracker/Reformer, $\mathrm{T},{ }^{\circ} \mathrm{C}\left({ }^{\circ} \mathrm{F}\right) / \mathrm{P}, \mathrm{psi}$ & $751(1383) / 23$ & $889(1633) / 23$ \\
\hline Steam Reforming & Yes & No \\
\hline \multicolumn{3}{|l|}{ Steam System } \\
\hline Pressure, psia & 800 & 850 \\
\hline Superheat temperature, ${ }^{\circ} \mathrm{C}\left({ }^{\circ} \mathrm{F}\right)$ & $538(1000)$ & $482(900)$ \\
\hline \multicolumn{3}{|l|}{ Mixed Alcohol Synthesis } \\
\hline Temperature, ${ }^{\circ} \mathrm{C}\left({ }^{\circ} \mathrm{F}\right)$ & $299(570)$ & $299(570)$ \\
\hline Pressure, psi & 2000 & 900 \\
\hline Methanol Recycle, $\%$ & $90 \%$ & $97 \%$ \\
\hline Liquid Hourly Space Velocity, v/v/h & 3000 & 6000 \\
\hline Catalyst life, years & 1 & 5 \\
\hline Feedstock Cost, \$/short ton & 0 & 0 \\
\hline \multicolumn{3}{|l|}{ Performance Results } \\
\hline \multicolumn{3}{|l|}{ Products } \\
\hline Ethanol, mmgal/y & 27 & 42 \\
\hline Propanol and high alcohols, million gal/y & 9 & 7 \\
\hline \multicolumn{3}{|l|}{ Yields } \\
\hline Ethanol, gal/ton dry feedstock & $\begin{array}{l}28 \text { MSW basis; } \\
38 \text { RDF basis }\end{array}$ & $\begin{array}{l}44 \text { MSW basis; } \\
55 \text { RDF basis }\end{array}$ \\
\hline Higher alcohols, gal/ton dry feedstock & $\begin{array}{l}9 \text { MSW basis; } \\
13 \text { RDF basis }\end{array}$ & $\begin{array}{l}8 \text { MSW basis; } \\
12 \text { RDF basis }\end{array}$ \\
\hline Net power for export. MW & 9 & 3 \\
\hline \multicolumn{3}{|l|}{ Cost Results } \\
\hline Capital cost, millions $\$$ (2008 basis) & $\$ 449$ & $\$ 313$ \\
\hline \multicolumn{3}{|l|}{ Operating Costs, \$/gal ethanol } \\
\hline Raw materials & 0.10 & 0.04 \\
\hline Waste disposal & 0.03 & 0.00 \\
\hline By-product credits & -1.83 & -1.03 \\
\hline Electricity & -0.17 & -0.04 \\
\hline Fixed costs & 0.87 & 0.44 \\
\hline Depreciation & 0.82 & 0.37 \\
\hline Average income tax & 0.56 & 0.25 \\
\hline Average return on investment & 1.47 & 0.68 \\
\hline $\begin{array}{l}\text { Minimum ethanol selling price, } \\
\$ / \text { gal }(10 \% \text { IRR })\end{array}$ & 1.85 & 0.71 \\
\hline
\end{tabular}


As can be seen in Figure 4-4, improved economics allow selling prices of less than $\$ 2 /$ gallon without a tipping fee for a $20 \%$ rate of return if these improvements were available today. Higher returns on investment can be had by increasing the tipping fee. The wood case represents the goal case at a feedstock cost of $\$ 60 /$ ton.

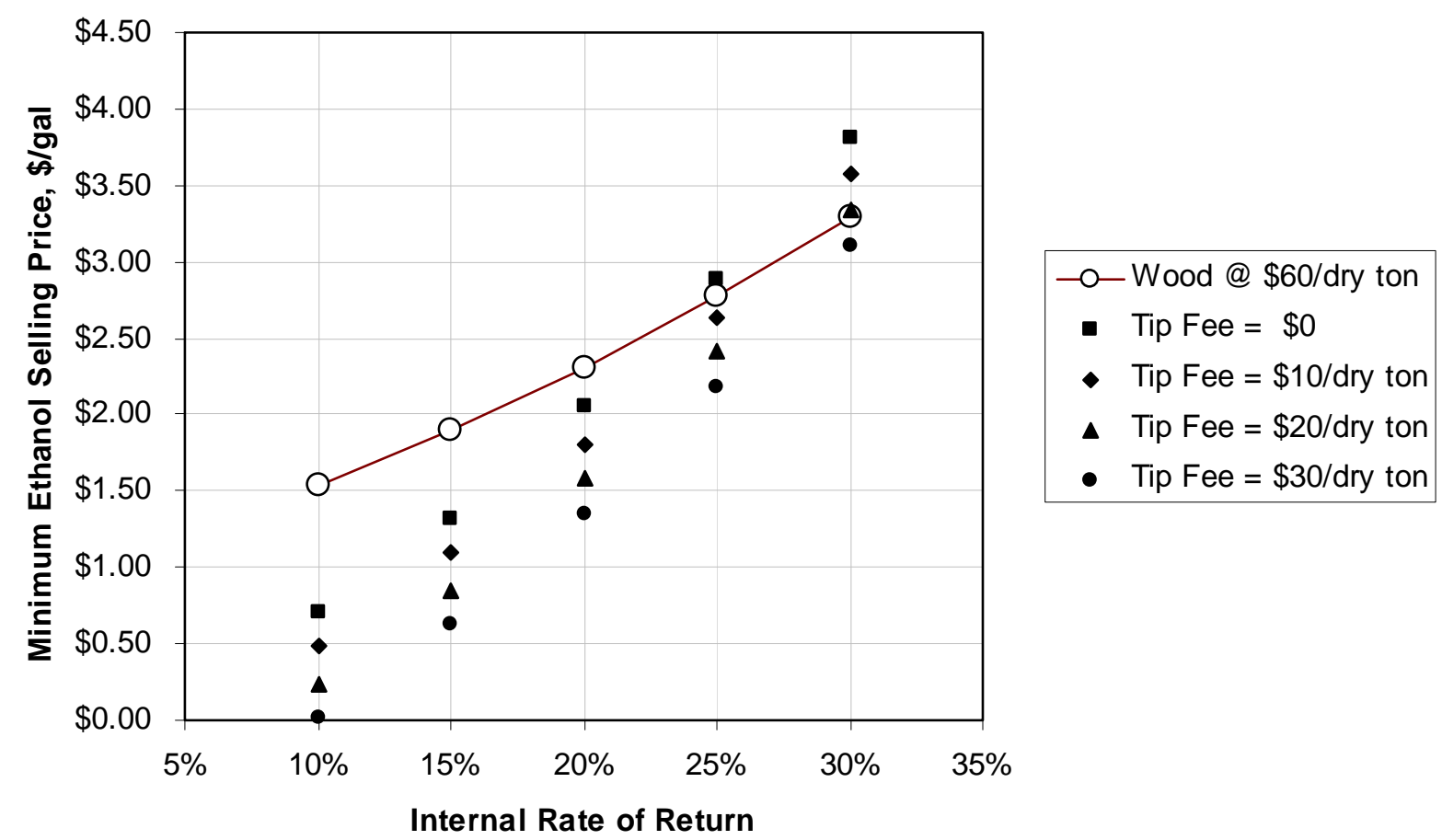

Figure 4-4 Effect of Improved Technology 


\subsection{Conclusions and Recommendations}

A techno-economic analysis of an MSW to ethanol process via gasification was conducted. The base case assumes that the MSW is obtained at zero cost and that the metals are recovered and sold as a byproduct. The base case process is based on currently available technology for syngas cleanup and mixed alcohols synthesis. The results of this study provide information about the main performance and economics for the systems. Sensitivity analysis was also conducted to investigate the effects of key assumptions on ethanol selling prices.

The capital required to produce mixed alcohols from MSW rather than from biomass is higher, due to the need to process the MSW into RDF. However, landfill-based operations offer the opportunity for zero or negative cost feedstock which offset the cost higher capital cost. The simulation results showed that the estimated ethanol selling price of $\$ 1.85$ /gallon (early 2008 dollars, $10 \%$ return on investment) for the indirectly-heated gasifier system, and assuming that the by-product metals are sold at a profit. $\$ 1.85 /$ gallon is competitive with early 2008 ethanol market prices, thus this process might be implemented today using existing technology. Other conclusions are as follows:

- The sale of RDF plant recyclables are a necessary part of an economic operation.

- Returns on investment of greater than $10 \%$ may be achieved by technological improvements in the syngas cleanup and mixed alcohol synthesis steps. In particular, implementing the 2012 timeframe improvements outlined in Phillips et al. (Phillips 2008) reduce the MESP by half.

- Waste streams from the process need to be tested for toxicity.

In addition, further work is needed to clarify the effect of MSW variability on RDF quality and gasifier operation. It would be useful to determine the economics of more mature products from MSW generated syngas, in particular, methanol, Fischer-Tropsch fuels, gasoline, synthetic natural gas as well as alternate means of processing besides gasification.

MSW is a potentially valuable, partially renewable feedstock that has been under utilized. This study provides potential research areas for process improvement. 


\subsection{References}

Aden, A. 2008. Biochemical Production of Ethanol from Corn Stover: 2007 State of Technology Model. NREL/TP-510-43205. National Renewable Energy Laboratory, Golden, CO. May 2008.

http://www.nrel.gov/docs/fy08osti/43205.pdf

Aden, A., P. Spath, and A. Atherton. 2005. The Potential of Thermochemical Ethanol Via Mixed Alcohols Production. Milestone Completion Report, FY05-684. National Renewable Energy Laboratory, Golden, CO. October 2005.

Caputo, A. C., and P. M. Palegagge. 2002. RDF Production Plants: I Design and Costs. Applied Thermal Engineering 22 (2002): 423-437.

Chang, N., Y. Chang, and W.C. Chen. 1997. Evaluation of Heat Value and Its Prediction for RefuseDerived Fuel. The Science of Total Environment (1997): 139-148.

Chemical Engineering Index. 2008. www.che.org

Dubanowitz, A. 2000. Design of a Materials Recovery Facility (MRF) for Processing the Recyclable Materials of New York City’s Municipal Solid Waste. MS Thesis, Columbia University. May 2000.

EIA, 2007. Methodology for Allocating Municipal Solid Waste to Biogenic and Non-Biogenic Energy. DOE/EIA-0226. Energy Information Administration, Office of Coal, Nuclear, Electric and Alternative Fuels, U.S. Department of energy, Washington, DC. May 2007.

http://www.eia.doe.gov/cneaf/solar.renewables/page/mswaste/msw.pdf

EIA, 2008. Monthly Energy Review Average Retail Prices of Electricity. January 2008 Industrial US Average. Energy Information Administration, Office of Coal, Nuclear, Electric and Alternative Fuels, U.S. Department of energy, Washington, DC. http://www.eia.doe.gov/emeu/mer/pdf/pages/sec9 14.pdf

EPA 2008. Municipal Solid Waste: Electricity from Municipal Solid Waste. EPA website accessed 10/2008. http://www.epa.gov/cleanenergy/energy-and-you/affect/municipal-sw.html

EPA 1997. Mercury Study Report to Congress, Volume 2. EPA-452/R-97-004. December 1997. http://www.epa.gov/ttncaaa1/t3/reports/volume2.pdf

Hamelinck, C.N. and A.P.C. Faaij, 2002. Future Prospects for Production of Methanol and Hydrogen from Biomass. Journal of Power Sources, 111 (1):1-22. 18 September 2002.

ICIS 2008. ICISPricing. Subscription pricing service available at: http://www.icispricing.com

Niessen, W.R., C.H. Marks, R.E. Sommerlad. 1996. Evaluation of Gasification and Novel Thermal Processes for the Treatment of Municipal Solid Waste. Camp, Dresser \& McKee. National Renewable Energy Laboratory. NREL/TP-430-21612. August 1996.

http://www.osti.gov/energycitations/servlets/purl/10164285-7CBnFx/webviewable/10164285.PDF 
Paisley, M.A., K.S. Creamer, T.L Tewksbury, and D.R. Taylor. 1989. Gasification of Refuse Derived Fuel in the Battelle High Throughput Gasification System. PNL-6998. Pacific Northwest National Laboratory, Richland, WA.

Parsons, 2002. The Cost of Mercury removal in an IGCC Plant. Final Report to DOE. September 2002. Parsons Infrastructure and Technology Group Inc.

http://www.netl.doe.gov/technologies/coalpower/gasification/pubs/pdf/MercuryRemoval\%20Final.pdf

Peer 1991. Material Recovery Facilities for Municipal Solid Waste. EPA 625/6-91/031. Peer Consulting and CalRecovery, Inc. United States Environmental Protection Agency. September 1991. http://www.epa.gov/nrmrl/pubs/625691031/625691031.pdf

Phillips, S., A. Aden, J. Jechura, and D. Dayton, 2007. Thermochemical Ethanol via Indirect Gasification and Mixed Alcohol Synthesis of Lignocellulosic Biomass. NREL/TP-510-41168. April 2007

Spath, P., A. Aden, T. Eggerman, M. Ringer, B. Wallace, J. Jechura, 2005. Biomass Hydrogen Production Detailed Design and Economics Utiltizing the Battelle Columbus Laboratory Indirectly Heated Gasifier. NREL/TP-510-37408. National Renewable Energy Laboratory, Golden, CO.

SRI PEP 2003 Yearbook International. SRI Consulting, United States. Menlo Park, CA. 2003.

SRI PEP 2007 Yearbook International. SRI Consulting, United States. Menlo Park, CA. 2007.

Taylor, J.T. 2008. Taylor Recycling Facility Pre-Development of Montgomery Site for Biomass Energy Generation Final Report. Contract 8997. http://www.taylorbiomassenergy.com/Images/NYSERDA.pdf

Thomspon, J. 2008. Uber Recycling. High Country News, 4(11) p. 8-9. September 9, 2008

USFN 2008. United States Federal News Service, Washington D.C. accessed 8-27-2008 through PROQUEST

Valkenburg, C, CW Walton, BL Thompson, MA Gerber, S. Jones, DJ Stevens. 2008. Municipal Solid Waste (MSW) to Liquid Fuels Synthesis, Volume 1: Availability of Feedstock and Technology. PNNL 18144, Pacific Northwest National Laboratory, Richland, WA.

WAC 173-306-200 Washington Administrative Code 173-306-200 Generator Management Plans. http://apps.leg.wa.gov/WAC/default.aspx?cite=173-306\&full=true\#173-306-200

Zhu Y, MA Gerber, SB Jones, and DJ Stevens. 2009. Analysis of the Effects of Compositional and Configurational Assumptions on Product Costs for the Thermochemical Conversion of Lignocellulosic Biomass to Mixed Alcohols - FY 2007 Progress Report. PNNL-17949 Revision 1, Pacific Northwest National Laboratory, Richland, WA. 
Appendix A. Heat and Material Balance for the Biomass Reference Case 
Figure A-1 Process Flow Diagram for the Biomass Reference Case

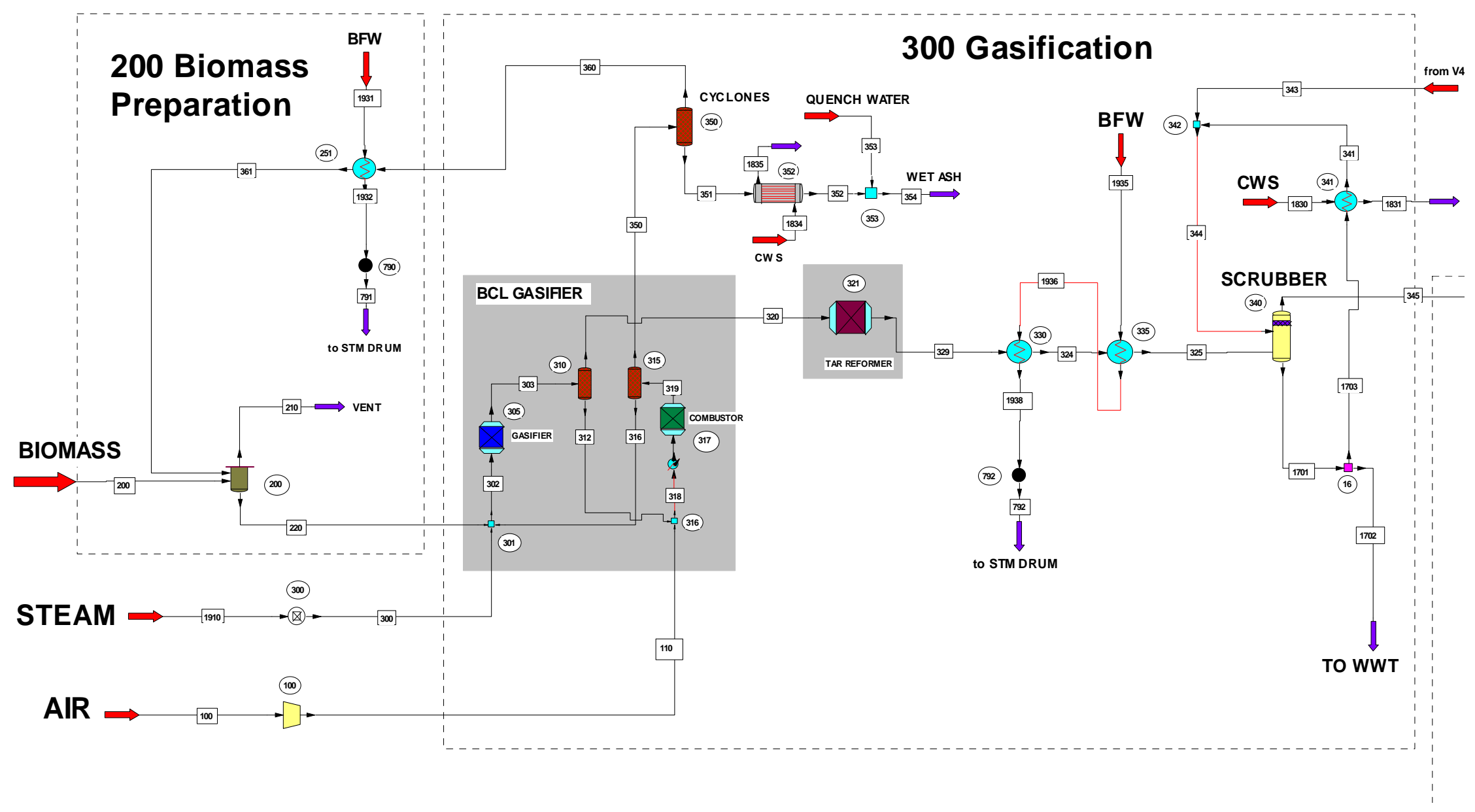


Figure A-1 Process Flow Diagram for the Biomass Reference Case (cont.)

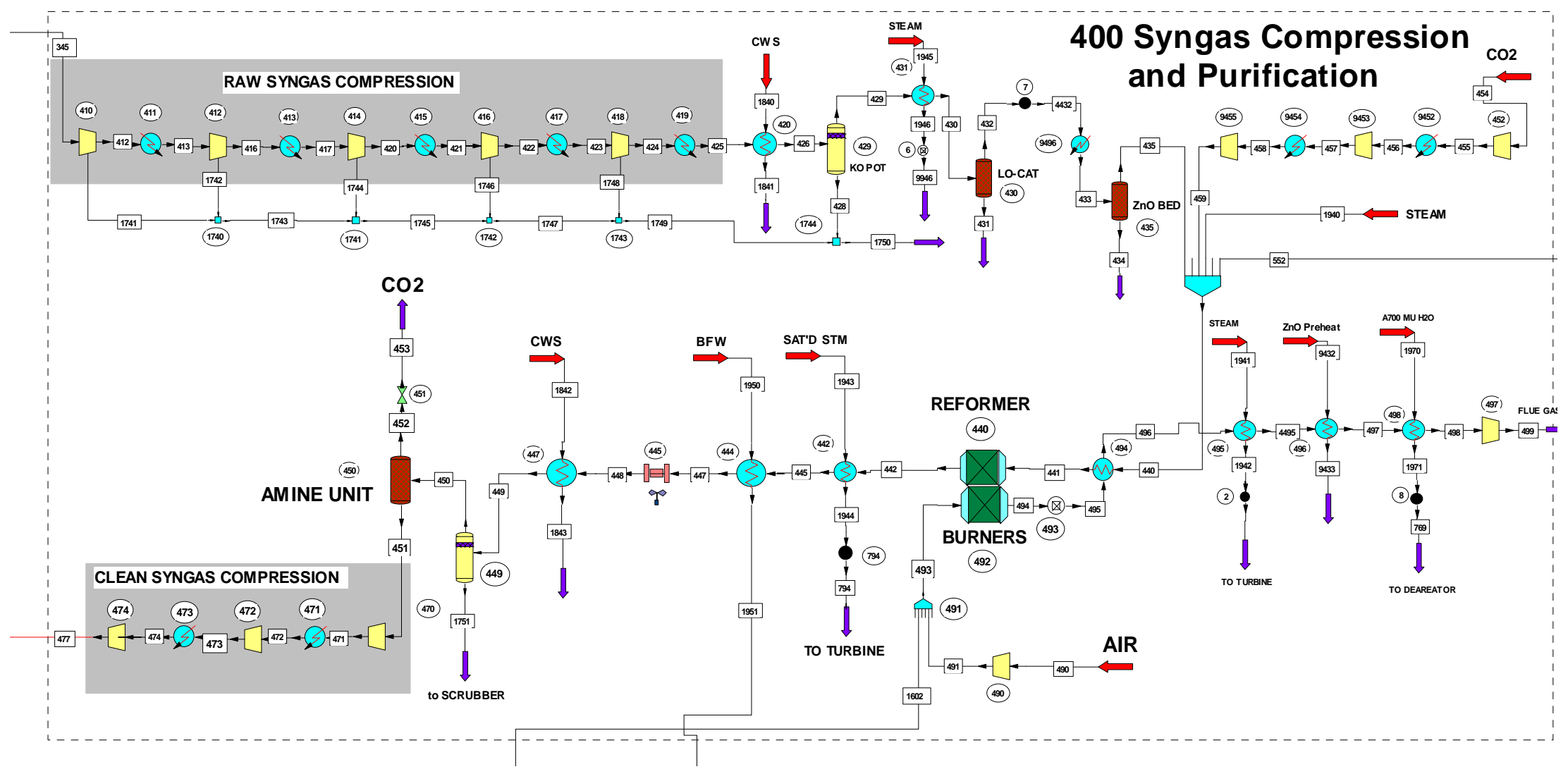


Figure A-1 Process Flow Diagram for the Biomass Reference Case (cont.)

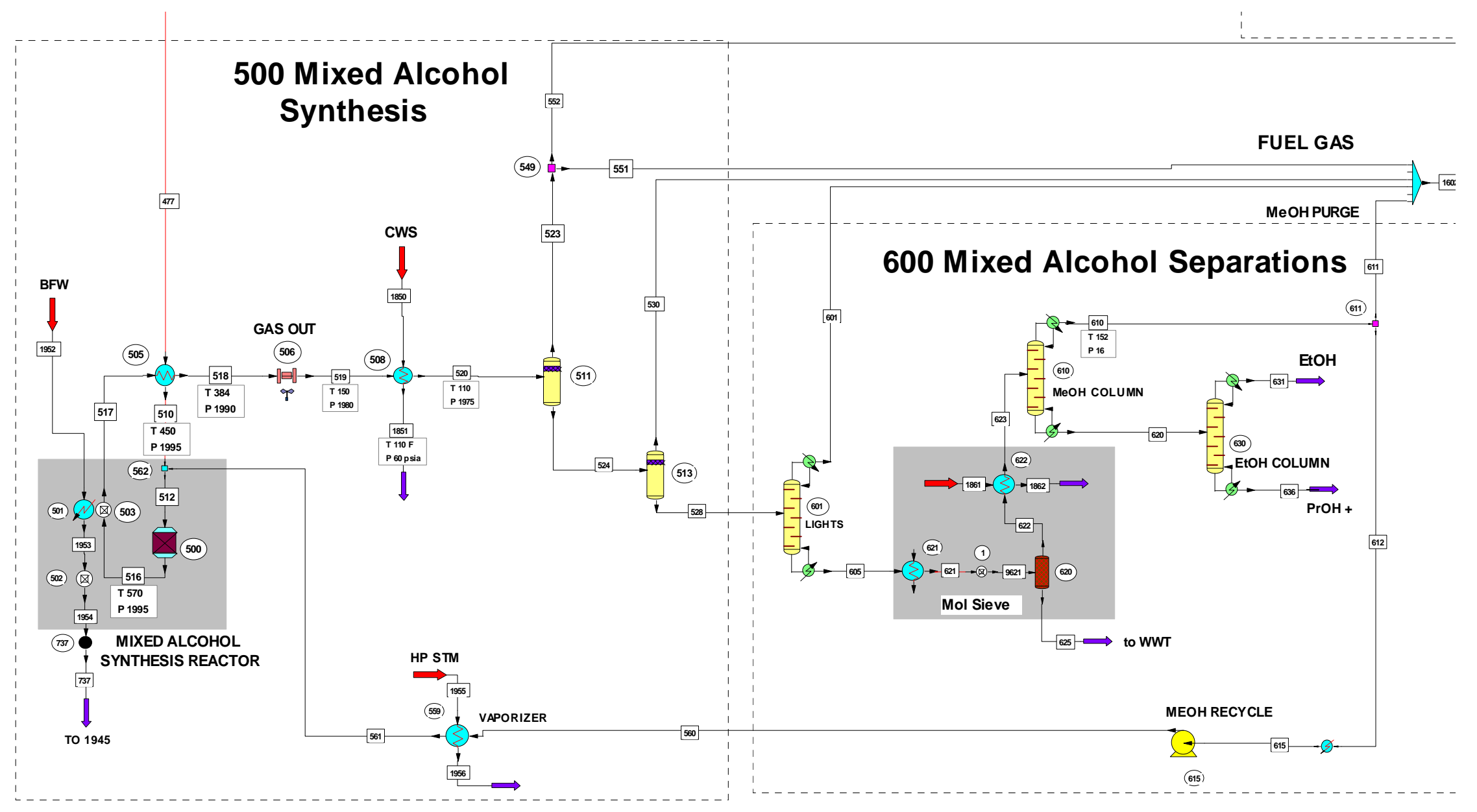


Figure A-1 Process Flow Diagram for the Biomass Reference Case (cont.)

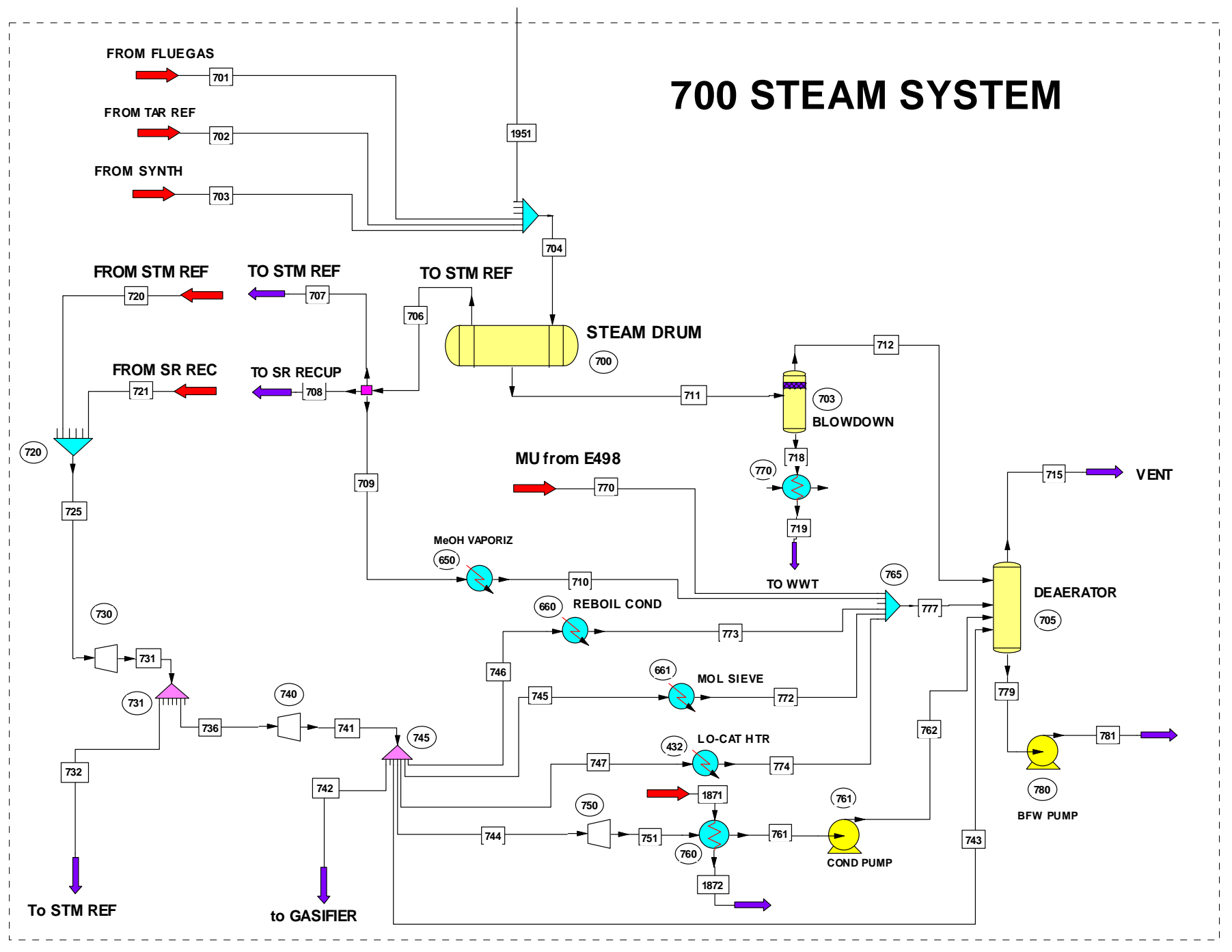


Table A-1 Stream Results for the Biomass Reference Case

\begin{tabular}{|c|c|c|c|c|c|c|c|c|c|c|c|c|c|c|c|}
\hline Stream No. & 5 & 100 & 110 & 200 & 210 & 220 & 300 & 302 & 303 & 312 & 316 & 318 & 319 & 320 & 324 \\
\hline Stream Name & \multicolumn{5}{|c|}{ BIOMASS VENT } & & & & & \multicolumn{6}{|c|}{ Syngas } \\
\hline Temp F & 1611.079 & 90 & 184.7633 & 60 & 225.2196 & 220 & 260 & 1737.218 & 1598 & 1598 & 1823 & 1523.3 & 1823 & 1598 & 464.2304 \\
\hline Pres psia & 22 & 14.696 & 22 & 25 & 22 & 22 & 25 & 22 & 23 & 23 & 22 & 22 & 22 & 23 & 19 \\
\hline Enth MMBtu/h & -8518.2 & -47.987 & -38.01 & -1692.5 & -1470.1 & -559.18 & -416.82 & -9151.3 & -9341.2 & -8670.1 & -8175.3 & -8708.1 & -8509.2 & -671.07 & -756.76 \\
\hline Vapor mass fraction & 1 & 1 & 1 & 0 & 1 & 0 & 1 & 0.33736 & 1 & 1 & 0 & 1 & 1 & 1 & 1 \\
\hline Total lb/h & 5418386 & 430413 & 430413 & 367437.4 & 628558 & 204132 & 73119.59 & 5228696 & 5228662 & 4987973 & 4951445 & 5418386 & 5418387 & 240689.4 & 240689.1 \\
\hline \multicolumn{16}{|l|}{ Flowrates in $\mathrm{lb} / \mathrm{h}$} \\
\hline Oxygen & 102708.3 & 97654.13 & 97654.13 & 0 & 11292.91 & 0 & 0 & 0 & 5054.145 & 5054.145 & 0 & 102708.3 & 11292.91 & 0 & 0 \\
\hline Nitrogen & 318713.3 & 318713.3 & 318713.3 & 0 & 318689 & 0 & 0 & 0 & 0 & 0 & 0 & 318713.3 & 318689 & 0 & 204.734 \\
\hline Argon & 5435.613 & 5435.613 & 5435.613 & 0 & 5435.613 & 0 & 0 & 0 & 0 & 0 & 0 & 5435.613 & 5435.613 & 0 & 0 \\
\hline Carbon & 27500.24 & 0 & 0 & 0 & 0 & 0 & 0 & 0 & 27500.24 & 27500.24 & 0 & 27500.24 & 0.0012 & 0 & 0 \\
\hline Hydrogen & 2282.96 & 0 & 0 & 0 & 0.0009 & 0 & 0 & 0 & 5461.737 & 2282.96 & 0 & 2282.96 & 0.0009 & 3178.778 & 6370.468 \\
\hline Carbon Monoxide & 0 & 0 & 0 & 0 & 0 & 0 & 0 & 0 & 78075.38 & 0 & 0 & 0 & 0 & 78075.38 & 98480.85 \\
\hline Carbon Dioxide & 212.2069 & 212.2069 & 212.2069 & 0 & 100981 & 0 & 0 & 0 & 37202.6 & 0 & 0 & 212.2069 & 100981 & 37202.59 & 37202.6 \\
\hline Methane & 0 & 0 & 0 & 0 & 0 & 0 & 0 & 0 & 16283.21 & 0 & 0 & 0 & 0 & 16283.21 & 13026.57 \\
\hline Acetylene & 0 & 0 & 0 & 0 & 0 & 0 & 0 & 0 & 701.6728 & 0 & 0 & 0 & 0 & 701.6727 & 350.8364 \\
\hline Ethylene & 0 & 0 & 0 & 0 & 0 & 0 & 0 & 0 & 8060.712 & 0 & 0 & 0 & 0 & 8060.713 & 4030.356 \\
\hline Ethane & 0 & 0 & 0 & 0 & 0 & 0 & 0 & 0 & 579.8716 & 0 & 0 & 0 & 0 & 579.8715 & 57.9872 \\
\hline Propane & 0 & 0 & 0 & 0 & 0 & 0 & 0 & 0 & 0 & 0 & 0 & 0 & 0 & 0 & 0 \\
\hline Water & 8397.746 & 8397.746 & 8397.746 & 183718.8 & 192107.1 & 20413.18 & 73119.59 & 93532.76 & 93532.76 & 0 & 0 & 8397.746 & 28801.52 & 93532.77 & 80408.71 \\
\hline Sulphur & 0 & 0 & 0 & 0 & 0 & 0 & 0 & 0 & 0 & 0 & 0 & 0 & 0 & 0 & 0 \\
\hline Carbonyl Sulfide & 0 & 0 & 0 & 0 & 0 & 0 & 0 & 0 & 0 & 0 & 0 & 0 & 0 & 0 & 0 \\
\hline Hydrogen Sulfide & 0 & 0 & 0 & 0 & 0 & 0 & 0 & 0 & 161.5833 & 0 & 0 & 0 & 0 & 161.5833 & 161.5833 \\
\hline Ammonia & 0 & 0 & 0 & 0 & 0 & 0 & 0 & 0 & 355.6206 & 0 & 0 & 0 & 0 & 355.6205 & 106.6862 \\
\hline HydrogenChloride & 0 & 0 & 0 & 0 & 0 & 0 & 0 & 0 & 0 & 0 & 0 & 0 & 0 & 0 & 0 \\
\hline Silicon Dioxide & 4951445 & 0 & 0 & 0 & 0 & 0 & 0 & 4951445 & 4951445 & 4951445 & 4951445 & 4951445 & 4951445 & 0 & 0 \\
\hline Calcium Oxide & 1690.211 & 0 & 0 & 0 & 0 & 0 & 0 & 0 & 1690.211 & 1690.211 & 0 & 1690.211 & 1690.222 & 0 & 0 \\
\hline Benzene & 0 & 0 & 0 & 0 & 0 & 0 & 0 & 0 & 639.3002 & 0 & 0 & 0 & 0 & 639.3002 & 191.7901 \\
\hline Naphthalene & 0 & 0 & 0 & 0 & 0 & 0 & 0 & 0 & 1917.901 & 0 & 0 & 0 & 0 & 1917.901 & 95.8951 \\
\hline Hybrid Pop NREL & 0.0041 & 0 & 0 & 183718.6 & 0 & 183718.6 & 0 & 183718.6 & 0.0041 & 0.0041 & 0 & 0.0041 & 0 & 0 & 0 \\
\hline Sulfur Dioxide & 0 & 0 & 0 & 0 & 0 & 0 & 0 & 0 & 0 & 0 & 0 & 0 & 0 & 0 & 0 \\
\hline Hydrogen Cyanide & 0 & 0 & 0 & 0 & 0 & 0 & 0 & 0 & 0 & 0 & 0 & 0 & 0 & 0 & 0 \\
\hline Nitric Oxide & 0 & 0 & 0 & 0 & 52.0559 & 0 & 0 & 0 & 0 & 0 & 0 & 0 & 52.0559 & 0 & 0 \\
\hline Methanol & 0 & 0 & 0 & 0 & 0 & 0 & 0 & 0 & 0 & 0 & 0 & 0 & 0 & 0 & 0 \\
\hline Ethanol & 0 & 0 & 0 & 0 & 0 & 0 & 0 & 0 & 0 & 0 & 0 & 0 & 0 & 0 & 0 \\
\hline Isopropanol & 0 & 0 & 0 & 0 & 0 & 0 & 0 & 0 & 0 & 0 & 0 & 0 & 0 & 0 & 0 \\
\hline N-Propanol & 0 & 0 & 0 & 0 & 0 & 0 & 0 & 0 & 0 & 0 & 0 & 0 & 0 & 0 & 0 \\
\hline Isobutanol & 0 & 0 & 0 & 0 & 0 & 0 & 0 & 0 & 0 & 0 & 0 & 0 & 0 & 0 & 0 \\
\hline N-Butanol & 0 & 0 & 0 & 0 & 0 & 0 & 0 & 0 & 0 & 0 & 0 & 0 & 0 & 0 & 0 \\
\hline 1-Pentanol & 0 & 0 & 0 & 0 & 0 & 0 & 0 & 0 & 0 & 0 & 0 & 0 & 0 & 0 & 0 \\
\hline
\end{tabular}




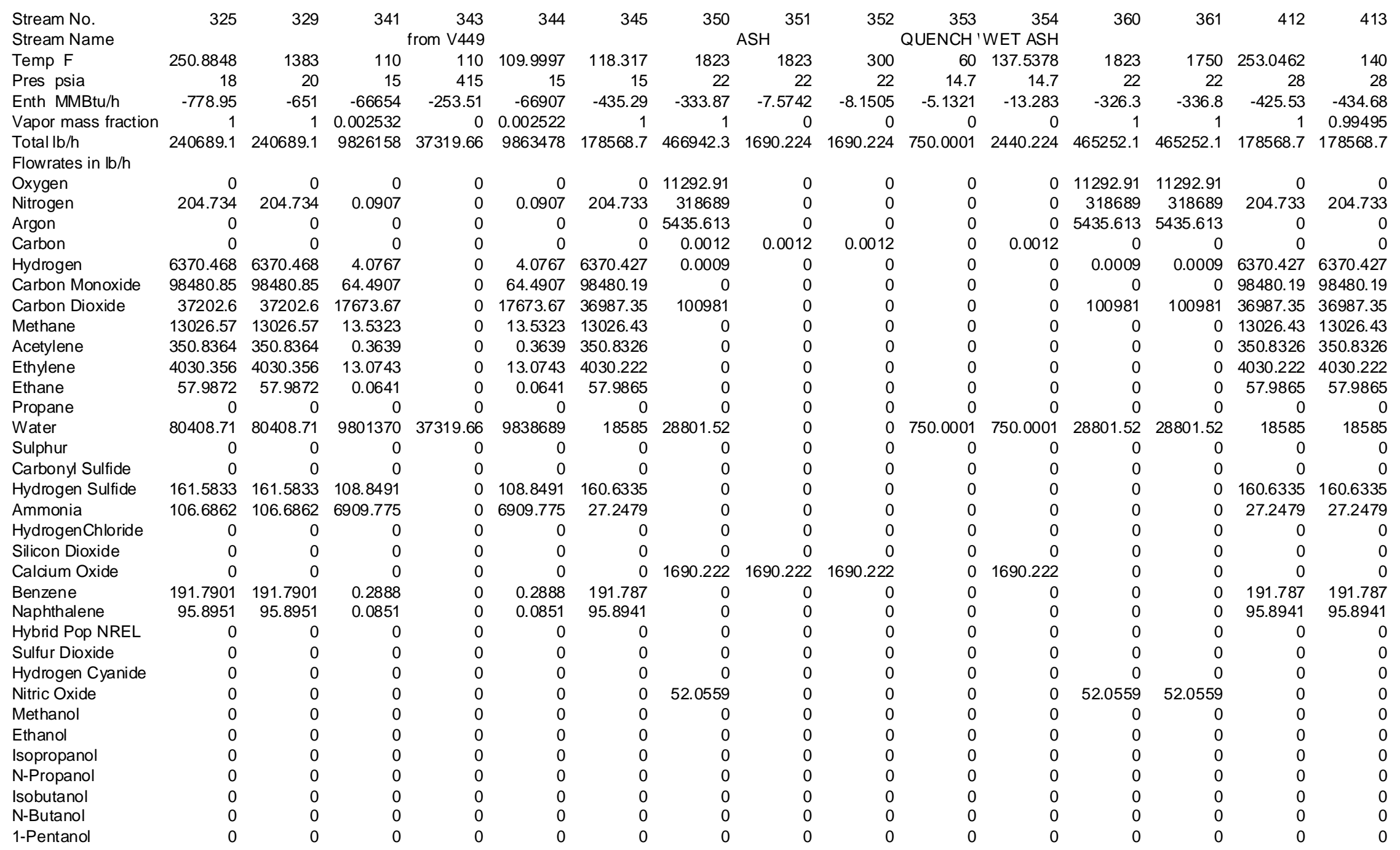




\begin{tabular}{|c|c|c|c|c|c|c|c|c|c|c|c|c|c|c|c|}
\hline $\begin{array}{l}\text { Stream No. } \\
\text { Stream Name }\end{array}$ & 416 & 417 & 420 & 421 & 422 & 423 & 424 & 425 & 426 & 428 & 429 & 430 & 431 & 432 & 433 \\
\hline Temp F & 274.5935 & 140 & 195.4107 & 140 & 209.0953 & 140 & 231.2065 & 140 & 110 & 110 & 110 & 120 & 120 & 120 & 707 \\
\hline Pres psia & 54 & 54 & 109.5 & 109.5 & 220 & 220 & 465 & 465 & 465 & 465 & 465 & 465 & 445 & 445 & 445 \\
\hline Enth MMBtu/h & -423.96 & -443.82 & -416.31 & -432.43 & -381.76 & -394.84 & -364.62 & -377.55 & -380.31 & -48.377 & -331.94 & -331.28 & 0 & -331.26 & -291.04 \\
\hline Vapor mass fraction & 1 & 0.94457 & 1 & 0.9317 & 1 & 0.95183 & 1 & 0.9609 & 0.9575 & 0 & 1 & 1 & 0 & 1 & 1 \\
\hline $\begin{array}{l}\text { Total lb/h } \\
\text { Flowrates in lb/h }\end{array}$ & 178568.7 & 178568.7 & 176201.6 & 176201.6 & 170321.2 & 170321.2 & 167569.5 & 167569.5 & 167569.5 & 7121.836 & 160447.6 & 160447.6 & 0 & 160447.6 & 160447.6 \\
\hline Oxygen & 0 & 0 & 0 & 0 & 0 & 0 & 0 & 0 & 0 & 0 & 0 & 0 & 0 & 0 & \\
\hline Nitrogen & 204.733 & 204.733 & 204.733 & 204.733 & 204.733 & 204.733 & 204.733 & 204.733 & 204.733 & 0 & 204.733 & 204.733 & 0 & 204.733 & 204.733 \\
\hline Argon & 0 & 0 & 0 & 0 & 0 & 0 & 0 & 0 & 0 & 0 & 0 & 0 & 0 & 0 & 0 \\
\hline Carbon & 0 & 0 & 0 & 0 & 0 & 0 & 0 & 0 & 0 & 0 & 0 & 0 & 0 & 0 & 0 \\
\hline Hydrogen & 6370.427 & 6370.427 & 6370.427 & 6370.427 & 6370.427 & 6370.427 & 6370.426 & 6370.426 & 6370.426 & 0 & 6370.426 & 6370.426 & 0 & 6370.426 & 6370.426 \\
\hline Carbon Monoxide & 98480.19 & 98480.19 & 98480.19 & 98480.19 & 98480.19 & 98480.19 & 98480.19 & 98480.19 & 98480.19 & 0 & 98480.19 & 98480.19 & 0 & 98480.19 & 98480.19 \\
\hline Carbon Dioxide & 36987.35 & 36987.35 & 36987.35 & 36987.35 & 36987.35 & 36987.35 & 36987.35 & 36987.35 & 36987.35 & 0 & 36987.35 & 36987.35 & 0 & 36987.35 & 36987.35 \\
\hline Methane & 13026.43 & 13026.43 & 13026.43 & 13026.43 & 13026.43 & 13026.43 & 13026.43 & 13026.43 & 13026.43 & 0 & 13026.43 & 13026.43 & 0 & 13026.43 & 13026.43 \\
\hline Acetylene & 350.8326 & 350.8326 & 350.8326 & 350.8326 & 350.8326 & 350.8326 & 350.8326 & 350.8326 & 350.8326 & 0 & 350.8326 & 350.8326 & 0 & 350.8326 & 350.8326 \\
\hline Ethylene & 4030.222 & 4030.222 & 4030.222 & 4030.222 & 4030.222 & 4030.222 & 4030.222 & 4030.222 & 4030.222 & 0 & 4030.222 & 4030.222 & 0 & 4030.222 & 4030.222 \\
\hline Ethane & 57.9865 & 57.9865 & 57.9865 & 57.9865 & 57.9865 & 57.9865 & 57.9865 & 57.9865 & 57.9865 & 0 & 57.9865 & 57.9865 & 0 & 57.9865 & 57.9865 \\
\hline Propane & 0 & 0 & 0 & 0 & 0 & 0 & 0 & 0 & 0 & 0 & 0 & 0 & 0 & 0 & 0 \\
\hline Water & 18585 & 18585 & 16217.9 & 16217.9 & 10337.51 & 10337.51 & 7585.755 & 7585.755 & 7585.755 & 7121.836 & 463.9131 & 463.9131 & 0 & 463.9131 & 463.9131 \\
\hline Sulphur & 0 & 0 & 0 & 0 & 0 & 0 & 0 & 0 & 0 & 0 & 0 & 0 & 0 & 0 & 0 \\
\hline Carbonyl Sulfide & 0 & 0 & 0 & 0 & 0 & 0 & 0 & 0 & 0 & 0 & 0 & 0 & 0 & 0 & 0 \\
\hline Hydrogen Sulfide & 160.6335 & 160.6335 & 160.6335 & 160.6335 & 160.6335 & 160.6335 & 160.6335 & 160.6335 & 160.6335 & 0 & 160.6335 & 160.6335 & 0 & 160.6335 & 160.6335 \\
\hline Ammonia & 27.2479 & 27.2479 & 27.2479 & 27.2479 & 27.2479 & 27.2479 & 27.2479 & 27.2479 & 27.2479 & 0 & 27.2479 & 27.2479 & 0 & 27.2479 & 27.2479 \\
\hline HydrogenChloride & 0 & 0 & 0 & 0 & 0 & 0 & 0 & 0 & 0 & 0 & 0 & 0 & 0 & 0 & 0 \\
\hline Silicon Dioxide & 0 & 0 & 0 & 0 & 0 & 0 & 0 & 0 & 0 & 0 & 0 & 0 & 0 & 0 & 0 \\
\hline Calcium Oxide & 0 & 0 & 0 & 0 & 0 & 0 & 0 & 0 & 0 & 0 & 0 & 0 & 0 & 0 & 0 \\
\hline Benzene & 191.787 & 191.787 & 191.787 & 191.787 & 191.787 & 191.787 & 191.787 & 191.787 & 191.787 & 0 & 191.787 & 191.787 & 0 & 191.787 & 191.787 \\
\hline Naphthalene & 95.8941 & 95.8941 & 95.8941 & 95.8941 & 95.8941 & 95.8941 & 95.8941 & 95.8941 & 95.8941 & 0 & 95.8941 & 95.8941 & 0 & 95.8941 & 95.8941 \\
\hline Hybrid Pop NREL & 0 & 0 & 0 & 0 & 0 & 0 & 0 & 0 & 0 & 0 & 0 & 0 & 0 & 0 & 0 \\
\hline Sulfur Dioxide & 0 & 0 & 0 & 0 & 0 & 0 & 0 & 0 & 0 & 0 & 0 & 0 & 0 & 0 & 0 \\
\hline Hydrogen Cyanide & 0 & 0 & 0 & 0 & 0 & 0 & 0 & 0 & 0 & 0 & 0 & 0 & 0 & 0 & 0 \\
\hline Nitric Oxide & 0 & 0 & 0 & 0 & 0 & 0 & 0 & 0 & 0 & 0 & 0 & 0 & 0 & 0 & 0 \\
\hline Methanol & 0 & 0 & 0 & 0 & 0 & 0 & 0 & 0 & 0 & 0 & 0 & 0 & 0 & 0 & 0 \\
\hline Ethanol & 0 & 0 & 0 & 0 & 0 & 0 & 0 & 0 & 0 & 0 & 0 & 0 & 0 & 0 & 0 \\
\hline Isopropanol & 0 & 0 & 0 & 0 & 0 & 0 & 0 & 0 & 0 & 0 & 0 & 0 & 0 & 0 & 0 \\
\hline N-Propanol & 0 & 0 & 0 & 0 & 0 & 0 & 0 & 0 & 0 & 0 & 0 & 0 & 0 & 0 & 0 \\
\hline Isobutanol & 0 & 0 & 0 & 0 & 0 & 0 & 0 & 0 & 0 & 0 & 0 & 0 & 0 & 0 & 0 \\
\hline N-Butanol & 0 & 0 & 0 & 0 & 0 & 0 & 0 & 0 & 0 & 0 & 0 & 0 & 0 & 0 & 0 \\
\hline 1-Pentanol & 0 & 0 & 0 & 0 & 0 & 0 & 0 & 0 & 0 & 0 & 0 & 0 & 0 & 0 & 0 \\
\hline
\end{tabular}




\begin{tabular}{|c|c|c|c|c|c|c|c|c|c|c|c|c|c|c|c|}
\hline $\begin{array}{l}\text { Stream No. } \\
\text { Stream Name }\end{array}$ & 434 & 435 & 440 & 441 & 442 & 445 & 447 & 448 & 449 & 450 & \multicolumn{2}{|c|}{${ }^{451} \mathrm{co} 2^{452}$} & 453 & $\mathrm{CO} 2$ & 455 \\
\hline Temp F & 707.0002 & 707 & 459.8756 & 930.0002 & 1652 & 1170.387 & 300.0607 & 150 & 110 & 110 & 120 & 120 & 57.4546 & 60 & 316.1531 \\
\hline Pres psia & 682 & 682 & 450 & 445 & 430 & 430 & 430 & 430 & 427.5 & 427.5 & 422.5 & 422.5 & 22 & 22 & 100 \\
\hline Enth MMBtu/h & -0.01686 & -290.95 & -1947.7 & -1828.7 & -1527 & -1663 & -1927.1 & -2042.1 & -2056.9 & -1236.2 & -432.73 & -803.75 & -803.75 & -609.7 & -601 \\
\hline Vapor mass fraction & 1 & 1 & 1 & 1 & 1 & 1 & 0.92981 & 0.80342 & 0.79916 & 1 & 1 & 0.995 & 0.99766 & 1 & 1 \\
\hline $\begin{array}{l}\text { Total lb/h } \\
\text { Flowrates in lb/h }\end{array}$ & 160.6335 & 160287 & 601582.1 & 601582 & 601582 & 601582 & 601582 & 601582 & 601582 & 480759 & 272761.6 & 207997.1 & 207997.1 & 158436 & 158436 \\
\hline Oxygen & 0 & 0 & 0 & 0 & 0 & 0 & 0 & 0 & 0 & 0 & 0 & 0 & 0 & 0 & ) \\
\hline Nitrogen & 0 & 204.733 & 667.2862 & 667.2863 & 680.811 & 680.811 & 680.811 & 680.811 & 680.811 & 680.811 & 680.811 & 0 & 0 & 0 & \\
\hline Argon & 0 & 0 & 0 & 0 & 0 & 0 & 0 & 0 & 0 & 0 & 0 & 0 & 0 & 0 & \\
\hline Carbon & 0 & 0 & 0 & 0 & 0 & 0 & 0 & 0 & 0 & 0 & 0 & 0 & 0 & 0 & 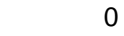 \\
\hline Hydrogen & 0 & 6370.426 & 13637.61 & 13637.61 & 19134.34 & 19134.34 & 19134.34 & 19134.34 & 19134.34 & 19134.34 & 19134.34 & 0 & 0 & 0 & 0 \\
\hline Carbon Monoxide & 0 & 98480.19 & 191381.6 & 191381.6 & 235921.5 & 235921.5 & 235921.5 & 235921.5 & 235921.5 & 235921.4 & 235921.4 & 0 & 0 & 0 & 0 \\
\hline Carbon Dioxide & 0 & 36987.35 & 226418.7 & 226418.7 & 208683.4 & 208683.4 & 208683.4 & 208683.4 & 208683.4 & 208683.4 & 2086.822 & 206596.6 & 206596.6 & 158436 & 158436 \\
\hline Methane & 0 & 13026.43 & 27171.88 & 27171.89 & 14917.88 & 14917.88 & 14917.88 & 14917.88 & 14917.88 & 14917.88 & 14917.88 & 0 & 0 & 0 & 0 \\
\hline Acetylene & 0 & 350.8326 & 350.8344 & 350.8345 & 0.0031 & 0.0031 & 0.0031 & 0.0031 & 0.0031 & 0.0031 & 0.0031 & 0 & 0 & 0 & 0 \\
\hline Ethylene & 0 & 4030.222 & 4030.67 & 4030.67 & 0.6849 & 0.6849 & 0.6849 & 0.6849 & 0.6849 & 0.6849 & 0.6849 & 0 & 0 & 0 & \\
\hline Ethane & 0 & 57.9865 & 469.5271 & 469.5272 & 1.5415 & 1.5415 & 1.5415 & 1.5415 & 1.5415 & 1.5415 & 1.5415 & 0 & 0 & 0 & U \\
\hline Propane & 0 & 0 & 0 & 0 & 0 & 0 & 0 & 0 & 0 & 0 & 0 & 0 & 0 & 0 & 0 \\
\hline Water & 0 & 463.9131 & 135730.5 & 135730.4 & 122223.7 & 122223.7 & 122223.7 & 122223.7 & 122223.7 & 1400.485 & 0 & 1400.485 & 1400.48 & 0 & 0 \\
\hline Sulphur & 0 & 0 & 0 & 0 & 0 & 0 & 0 & 0 & 0 & 0 & 0 & 0 & 0 & 0 & 0 \\
\hline Carbonyl Sulfide & 0 & 0 & 0 & 0 & 0 & 0 & 0 & 0 & 0 & 0 & 0 & 0 & 0 & 0 & 0 \\
\hline Hydrogen Sulfide & 160.6335 & 0 & 0 & 0 & 0 & 0 & 0 & 0 & 0 & 0 & 0 & 0 & 0 & 0 & 0 \\
\hline Ammonia & 0 & 27.2479 & 34.2377 & 34.2377 & 17.6516 & 17.6516 & 17.6516 & 17.6516 & 17.6516 & 17.6516 & 17.6516 & 0 & 0 & 0 & 0 \\
\hline HydrogenChloride & 0 & 0 & 0 & 0 & 0 & 0 & 0 & 0 & 0 & 0 & 0 & 0 & 0 & 0 & 0 \\
\hline Silicon Dioxide & 0 & 0 & 0 & 0 & 0 & 0 & 0 & 0 & 0 & 0 & 0 & 0 & 0 & 0 & 0 \\
\hline Calcium Oxide & 0 & 0 & 0 & 0 & 0 & 0 & 0 & 0 & 0 & 0 & 0 & 0 & 0 & 0 & 0 \\
\hline Benze & 0 & 191.787 & 191.7869 & 191.787 & 0 & 0 & 0 & 0 & 0 & 0 & 0 & 0 & 0 & 0 & 0 \\
\hline Naphthalene & 0 & 95.8941 & 95.8941 & 95.8941 & 0 & 0 & 0 & 0 & 0 & 0 & 0 & 0 & 0 & 0 & 0 \\
\hline Hybrid Pop NREL & 0 & 0 & 0 & 0 & 0 & 0 & 0 & 0 & 0 & 0 & 0 & 0 & 0 & 0 & 0 \\
\hline Sulfur Dioxide & 0 & 0 & 0 & 0 & 0 & 0 & 0 & 0 & 0 & 0 & 0 & 0 & 0 & 0 & 0 \\
\hline Hydrogen Cyanide & 0 & 0 & 0.0618 & 0.0618 & 0.2912 & 0.2912 & 0.2912 & 0.2912 & 0.2912 & 0.2912 & 0.2912 & 0 & 0 & 0 & 0 \\
\hline Nitric Oxide & 0 & 0 & 0 & 0 & 0 & 0 & 0 & 0 & 0 & 0 & 0 & 0 & 0 & 0 & 0 \\
\hline Methanol & 0 & 0 & 492.663 & 492.6631 & 0.1196 & 0.1196 & 0.1196 & 0.1196 & 0.1196 & 0.1196 & 0.1196 & 0 & 0 & 0 & 0 \\
\hline Ethanol & 0 & 0 & 792.6373 & 792.6376 & 0.0001 & 0.0001 & 0.0001 & 0.0001 & 0.0001 & 0.0001 & 0.0001 & 0 & 0 & 0 & 0 \\
\hline Isoprop & 0 & 0 & 0 & 0 & 0 & 0 & 0 & 0 & 0 & 0 & 0 & 0 & 0 & 0 & 0 \\
\hline N-Propanol & 0 & 0 & 87.9436 & 87.9436 & 0 & 0 & 0 & 0 & 0 & 0 & 0 & 0 & 0 & 0 & 0 \\
\hline Isobutanol & 0 & 0 & 0 & 0 & 0 & 0 & 0 & 0 & 0 & 0 & 0 & 0 & 0 & 0 & 0 \\
\hline N-Butanol & 0 & 0 & 19.1715 & 19.1715 & 0 & 0 & 0 & 0 & 0 & 0 & 0 & 0 & 0 & 0 & 0 \\
\hline 1-Pentanol & 0 & 0 & 8.9839 & 8.9839 & 0 & 0 & 0 & 0 & 0 & 0 & 0 & 0 & 0 & 0 & 0 \\
\hline
\end{tabular}




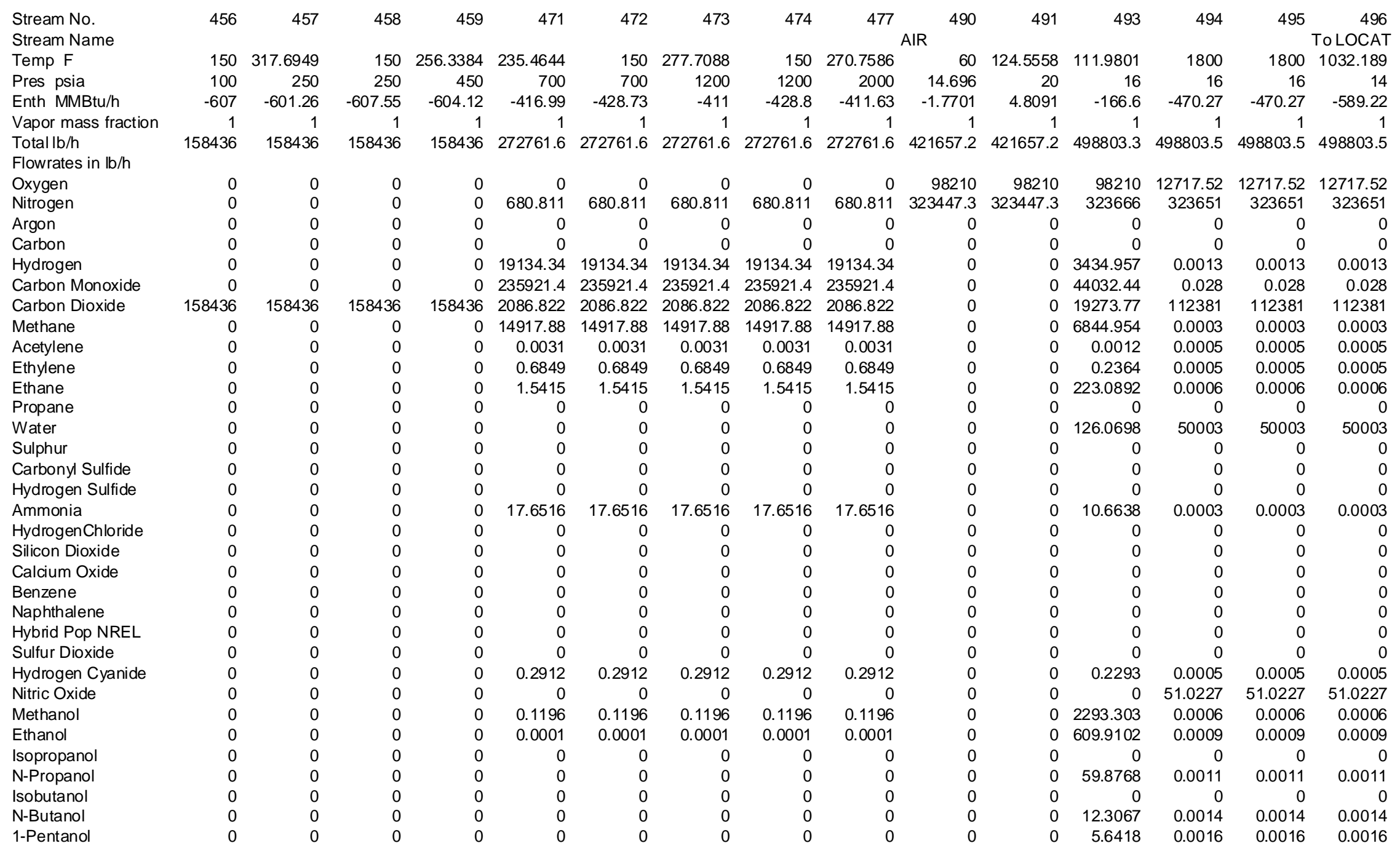




\begin{tabular}{|c|c|c|c|c|c|c|c|c|c|c|c|c|c|c|c|}
\hline Stream No. & 497 & 498 & 499 & 510 & 512 & 516 & 517 & 518 & 519 & 520 & 523 & 524 & 528 & 530 & 551 \\
\hline Stream Name & FLUE GAS & & & & & & GAS OUT & & & & & TO WWT & & & \\
\hline Temp F & 469.7888 & 280 & 297.8397 & 450 & 451.0664 & 570 & 570 & 383.6532 & 150 & 110 & 110.2585 & 110.2585 & 101.7292 & 101.7292 & 110.2585 \\
\hline Pres psia & 14 & 14 & 15 & 1995 & 1995 & 1995 & 1995 & 1990 & 1980 & 1975 & 1975 & 1975 & 35 & 35 & 1975 \\
\hline Enth MMBtu/h & -668.94 & -694.37 & -692.01 & -386.4 & -418.49 & -580.02 & -580.02 & -605.26 & -657.23 & -664.53 & -454.55 & -209.97 & -193.71 & -16.261 & -145.46 \\
\hline Vapor mass fraction & 1 & 1 & 1 & 1 & 1 & 1 & 1 & 1 & 0.78186 & 0.76503 & 1 & 0 & 0 & 1 & 1 \\
\hline $\begin{array}{l}\text { Total lb/h } \\
\text { Flowrates in lb/h }\end{array}$ & 498803.5 & 498803.5 & 498803.5 & 272761.6 & 284142.6 & 284144.6 & 284144.6 & 284144.6 & 284144.6 & 284144.6 & 217274.2 & 66870.41 & 62228.29 & 4642.12 & 69527.73 \\
\hline xygen & 12717.52 & 12717.52 & 12717.52 & 0 & 0 & 0 & 0 & 0 & 0 & 0 & 0 & 0 & 0 & 0 & 0 \\
\hline trog & 323651 & 323651 & 323651 & 680.811 & 681.2112 & 681.211 & 681.211 & 681.211 & 681.211 & 681.211 & 680.2254 & 0.9856 & 0.0024 & 0.9832 & 217.6721 \\
\hline Argon & 0 & 0 & 0 & 0 & 0 & 0 & 0 & 0 & 0 & 0 & 0 & 0 & 0 & 0 & 0 \\
\hline Carbon & 0 & 0 & 0 & 0 & 0 & 0 & 0 & 0 & 0 & 0 & 0 & 0 & 0 & 0 & 0 \\
\hline Hydro & 0.0013 & 0.0013 & 0.0013 & 19134.34 & 19130.62 & 10702.14 & 10702.14 & 10702.14 & 10702.14 & 10702.14 & 10687.04 & 15.1045 & 0.0318 & 15.0728 & 3419.852 \\
\hline oxide & 0.028 & 0.028 & 0.028 & 235921.5 & 235887.4 & 136934 & 136934 & 136934 & 136934 & 136934 & 136619.8 & 314.1132 & 1.2259 & 312.8874 & 43718.33 \\
\hline xide & 112381 & 112381 & 112381 & 2086.822 & 2086.908 & 50269.07 & 50269.07 & 50269.07 & 50269.07 & 50269.07 & 45581.32 & 4687.747 & 986.0571 & 3701.69 & 14586.02 \\
\hline Metha & 0.0003 & 0.0003 & 0.0003 & 14917.89 & 14910.61 & 20990.42 & 20990.42 & 20990.42 & 20990.42 & 20990.42 & 20802.15 & 188.2663 & 3.3535 & 184.9128 & 6656.688 \\
\hline Acet & 0.0005 & 0.0005 & 0.0005 & 0.0031 & 0.0031 & 0.0031 & 0.0031 & 0.0031 & 0.0031 & 0.0031 & 0.0028 & 0.0002 & 0 & 0.0002 & 0.0009 \\
\hline hy & 0.0005 & 0.0005 & 0.0005 & 0.6849 & 0.6844 & 0.6844 & 0.6844 & 0.6844 & 0.6844 & 0.6844 & 0.6589 & 0.0256 & 0.0023 & 0.0233 & 0.2108 \\
\hline Ethe & 0.0006 & 0.0006 & 0.0006 & 1.5415 & 1.5403 & 634.6297 & 634.6297 & 634.6297 & 634.6297 & 634.6297 & 605.2066 & 29.4231 & 3.3546 & 26.0685 & 193.6661 \\
\hline Prop & 0 & 0 & 0 & 0 & 0 & 0 & 0 & 0 & 0 & 0 & 0 & 0 & 0 & 0 & 0 \\
\hline at & 50003 & 50003 & 50003 & 0 & 0 & 7281.481 & 7281.481 & 7281.481 & 7281.481 & 7281.481 & 226.5492 & 7054.934 & 7001.711 & 53.2222 & 72.4957 \\
\hline Sulphur & 0 & 0 & 0 & 0 & 0 & 0 & 0 & 0 & 0 & 0 & 0 & 0 & 0 & 0 & 0 \\
\hline Carb & 0 & 0 & 0 & 0 & 0 & 0 & 0 & 0 & 0 & 0 & 0 & 0 & 0 & 0 & 0 \\
\hline fide & 0 & 0 & 0 & 0 & 0 & 0 & 0 & 0 & 0 & 0 & 0 & 0 & 0 & 0 & 0 \\
\hline Amn & 0.0003 & 0.0003 & 0.0003 & 17.6516 & 17.6536 & 17.6537 & 17.6537 & 17.6537 & 17.6537 & 17.6537 & 10.2791 & 7.3745 & 5.0573 & 2.3172 & 3.2893 \\
\hline Hyd & 0 & 0 & 0 & 0 & 0 & 0 & 0 & 0 & 0 & 0 & 0 & 0 & 0 & 0 & 0 \\
\hline Silic & 0 & 0 & 0 & 0 & 0 & 0 & 0 & 0 & 0 & 0 & 0 & 0 & 0 & 0 & 0 \\
\hline Calc & 0 & 0 & 0 & 0 & 0 & 0 & 0 & 0 & 0 & 0 & 0 & 0 & 0 & 0 & 0 \\
\hline & 0 & 0 & 0 & 0 & 0 & 0 & 0 & 0 & & 0 & 0 & 0 & & 0 & 0 \\
\hline & 0 & 0 & 0 & 0 & 0 & 0 & 0 & 0 & 0 & 0 & 0 & 0 & & 0 & 0 \\
\hline lb & 0 & 0 & 0 & c & 0 & 0 & 0 & 0 & 0 & 0 & c & 0 & 0 & 0 & 0 \\
\hline Sulfu & 0 & 0 & 0 & 0 & 0 & 0 & 0 & 0 & 0 & 0 & 0 & 0 & 0 & 0 & 0 \\
\hline Cyanide & 0.0005 & 0.0005 & 0.0005 & 0.2912 & 0.2912 & 0.2912 & 0.2912 & 0.2912 & 0.2912 & 0.2912 & 0.0909 & 0.2002 & 0.1813 & 0.0189 & 0.0291 \\
\hline Nitric & 51.0227 & 51.0227 & 51.0227 & 0 & 0 & 0 & 0 & 0 & 0 & 0 & 0 & 0 & 0 & 0 & 0 \\
\hline Meth & 0.0006 & 0.0006 & 0.0006 & 0.1196 & 11398.28 & 4312.07 & 14312.07 & 4312.07 & 14312.07 & 14312.07 & 724.5045 & 13587.57 & 13465.86 & 121.7069 & 231.8414 \\
\hline Etha & 0.0009 & 0.0009 & 0.0009 & 0.0001 & 27.1554 & 31646.65 & 31646.65 & 31646.65 & 31646.65 & 31646.65 & 1165.643 & 30481.02 & 30280.96 & 200.0588 & 373.0058 \\
\hline & 0 & 0 & 0 & 0 & 0 & 0 & 0 & 0 & 0 & 0 & 0 & 0 & 0 & 0 & 0 \\
\hline & 0.0011 & 0.0011 & 0.0011 & c & 0.2859 & 6557.749 & 6557.749 & 6557.749 & 6557.749 & 6557.749 & 129.3288 & 6428.421 & 6409.961 & 18.4592 & 41.3852 \\
\hline & 0 & 0 & 0 & & 0 & 0 & 0 & 0 & 0 & 0 & 0 & 0 & 0 & 0 & 0 \\
\hline & 0014 & 0014 & 0014 & 0 & 0 & 2747.122 & 2747.122 & 2747.122 & 2747.122 & 2747.122 & 28.1934 & 2718.929 & 2715.644 & 3.2848 & 9.0219 \\
\hline 1-Pentanol & 0.0016 & 0.0016 & 0.0016 & 0 & 0 & 1369.51 & 1369.51 & 1369.51 & 1369.51 & 1369.51 & 13.2117 & 1356.298 & 1354.884 & 1.414 & 4.2277 \\
\hline
\end{tabular}




\begin{tabular}{|c|c|c|c|c|c|c|c|c|c|c|c|c|c|c|c|}
\hline Stream No. & 552 & 560 & 561 & 601 & 605 & 610 & 611 & 612 & 615 & 620 & 621 & 622 & 623 & \multirow{2}{*}{\multicolumn{2}{|c|}{ to WWT $^{625}$ EtOH }} \\
\hline Stream Name & & & & & \multicolumn{2}{|c|}{$\mathrm{MeOH}$} & \multicolumn{4}{|c|}{ MeOH PUFMeOH RECYCLE } & \multicolumn{3}{|c|}{ Mixed $\mathrm{OH}$} & & \\
\hline Temp F & 110.2585 & 167.2547 & 480 & 136.2132 & 194.8936 & 152.0138 & 152.0138 & 152.0138 & 152.0138 & 197.9772 & 193.9325 & 193.9326 & 187.4027 & 193.9326 & 176.7088 \\
\hline Pres psia & 1975 & 2000 & 1995 & 23 & 26.7 & 16 & 16 & 16 & 16 & 22 & 26.7 & 23 & 23 & 23 & 16 \\
\hline Enth MMBtu/h & -309.1 & -35.947 & -32.154 & -5.6871 & -183.46 & -40.074 & -4.0074 & -36.067 & -36.067 & -96.767 & -157.24 & -132.03 & -136.85 & -46.917 & -76.788 \\
\hline Vapor mass fraction & 1 & 0 & 1 & 1 & 0 & 0 & 0 & 0 & 0 & 0 & 1 & 0.2243 & 2.85E-06 & 0 & 0 \\
\hline $\begin{array}{l}\text { Total lb/h } \\
\text { Flowrates in lb/h }\end{array}$ & 147746.4 & 11425.6 & 11425.6 & 1706.739 & 60521.55 & 12695.11 & 1269.511 & 11425.6 & 11425.6 & 40825.07 & 60521.55 & 53520.18 & 53520.18 & 7001.335 & 30393.73 \\
\hline Oxygen & 0 & 0 & 0 & 0 & 0 & 0 & 0 & 0 & 0 & 0 & 0 & 0 & 0 & 0 & 0 \\
\hline Nitrogen & 462.5533 & 0 & 0 & 0.0024 & 0 & 0 & 0 & 0 & 0 & 0 & 0 & 0 & 0 & 0 & 0 \\
\hline Argon & 0 & 0 & 0 & 0 & 0 & 0 & 0 & 0 & 0 & 0 & 0 & 0 & 0 & 0 & 0 \\
\hline Carbon & 0 & 0 & 0 & 0 & 0 & 0 & 0 & 0 & 0 & 0 & 0 & 0 & 0 & 0 & 0 \\
\hline Hydrogen & 7267.187 & 0 & 0 & 0.0318 & 0 & 0 & 0 & 0 & 0 & 0 & 0 & 0 & 0 & 0 & 0 \\
\hline Carbon Monoxide & 92901.45 & 0 & 0 & 1.2259 & 0 & 0 & 0 & 0 & 0 & 0 & 0 & 0 & 0 & 0 & 0 \\
\hline Carbon Dioxide & 30995.3 & 0 & 0 & 986.0571 & 0 & 0 & 0 & 0 & 0 & 0 & 0 & 0 & 0 & 0 & 0 \\
\hline Methane & 14145.46 & 0 & 0 & 3.3535 & 0 & 0 & 0 & 0 & 0 & 0 & 0 & 0 & 0 & 0 & 0 \\
\hline Acetylene & 0.0019 & 0 & 0 & 0 & 0 & 0 & 0 & 0 & 0 & 0 & 0 & 0 & 0 & 0 & 0 \\
\hline Ethylene & 0.448 & 0 & 0 & 0.0023 & 0 & 0 & 0 & 0 & 0 & 0 & 0 & 0 & 0 & 0 & 0 \\
\hline Ethane & 411.5405 & 0 & 0 & 3.3546 & 0 & 0 & 0 & 0 & 0 & 0 & 0 & 0 & 0 & 0 & 0 \\
\hline Propane & 0 & 0 & 0 & 0 & 0 & 0 & 0 & 0 & 0 & 0 & 0 & 0 & 0 & 0 & 0 \\
\hline Water & 154.0534 & 0 & 0 & 0.3518 & 7001.359 & 0 & 0 & 0 & 0 & 0 & 7001.359 & 0 & 0 & 7001.335 & 0 \\
\hline Sulphur & 0 & 0 & 0 & 0 & 0 & 0 & 0 & 0 & 0 & 0 & 0 & 0 & 0 & 0 & 0 \\
\hline Carbonyl Sulfide & 0 & 0 & 0 & 0 & 0 & 0 & 0 & 0 & 0 & 0 & 0 & 0 & 0 & 0 & 0 \\
\hline Hydrogen Sulfide & 0 & 0 & 0 & 0 & 0 & 0 & 0 & 0 & 0 & 0 & 0 & 0 & 0 & 0 & 0 \\
\hline Ammonia & 6.9898 & 0 & 0 & 5.0573 & 0 & 0 & 0 & 0 & 0 & 0 & 0 & 0 & 0 & 0 & 0 \\
\hline HydrogenChloride & 0 & 0 & 0 & 0 & 0 & 0 & 0 & 0 & 0 & 0 & 0 & 0 & 0 & 0 & 0 \\
\hline Silicon Dioxide & 0 & 0 & 0 & 0 & 0 & 0 & 0 & 0 & 0 & 0 & 0 & 0 & 0 & 0 & 0 \\
\hline Calcium Oxide & 0 & 0 & 0 & 0 & 0 & 0 & 0 & 0 & 0 & 0 & 0 & 0 & 0 & 0 & 0 \\
\hline Benzene & 0 & 0 & 0 & 0 & 0 & 0 & 0 & 0 & 0 & 0 & 0 & 0 & 0 & 0 & 0 \\
\hline Naphthalene & 0 & 0 & 0 & 0 & 0 & 0 & 0 & 0 & 0 & 0 & 0 & 0 & 0 & 0 & 0 \\
\hline Hybrid Pop NREL & 0 & 0 & 0 & 0 & 0 & 0 & 0 & 0 & 0 & 0 & 0 & 0 & 0 & 0 & 0 \\
\hline Sulfur Dioxide & 0 & 0 & 0 & 0 & 0 & 0 & 0 & 0 & 0 & 0 & 0 & 0 & 0 & 0 & 0 \\
\hline Hydrogen Cyanide & 0.0618 & 0 & 0 & 0.1813 & 0 & 0 & 0 & 0 & 0 & 0 & 0 & 0 & 0 & 0 & 0 \\
\hline Nitric Oxide & 0 & 0 & 0 & 0 & 0 & 0 & 0 & 0 & 0 & 0 & 0 & 0 & 0 & 0 & 0 \\
\hline Methanol & 492.6631 & 11398.16 & 11398.16 & 673.2924 & 12792.57 & 12664.62 & 1266.462 & 11398.16 & 11398.16 & 127.9357 & 12792.57 & 12792.56 & 12792.56 & 0 & 127.7901 \\
\hline Ethanol & 792.6373 & 27.1553 & 27.1553 & 33.8283 & 30247.13 & 30.1726 & 3.0173 & 27.1553 & 27.1553 & 30216.97 & 30247.13 & 30247.14 & 30247.14 & 0 & 30201.85 \\
\hline Isopropanol & 0 & 0 & 0 & 0 & 0 & 0 & 0 & 0 & 0 & 0 & 0 & 0 & 0 & 0 & 0 \\
\hline N-Propanol & 87.9436 & 0.2859 & 0.2859 & 0.0007 & 6409.961 & 0.3176 & 0.0318 & 0.2859 & 0.2859 & 6409.638 & 6409.961 & 6409.955 & 6409.955 & 0 & 64.0946 \\
\hline Isobutanol & 0 & 0 & 0 & 0 & 0 & 0 & 0 & 0 & 0 & 0 & 0 & 0 & 0 & 0 & 0 \\
\hline N-Butanol & 19.1715 & 0 & 0 & 0 & 2715.644 & 0 & 0 & 0 & 0 & 2715.64 & 2715.644 & 2715.64 & 2715.64 & 0 & 0 \\
\hline 1-Pentanol & 8.9839 & 0 & 0 & 0 & 1354.884 & 0 & 0 & 0 & 0 & 1354.882 & 1354.884 & 1354.882 & 1354.882 & 0 & 0 \\
\hline
\end{tabular}


Stream No.

Stream Name PrOH

$$
709
$$

710

711

712 VENT 71

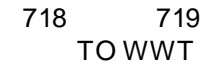

Pres psia

$\begin{array}{lllll}230.5994 & 526.5776 & 526.5776 & 526.5776 & 526.5776\end{array}$

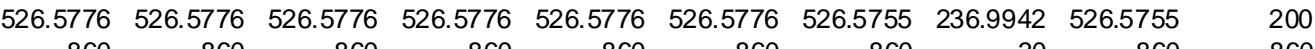

$\begin{array}{rrrrrrrrrrrrr}860 & 860\end{array}$

$\begin{array}{lllll}-20.195 & -60.648 & -738.52 & -932.53 & -3256\end{array}$

$\begin{array}{rrrr}0.99 & 0.99 & 0.98971 & 0.98991\end{array}$

$-3219.3$

$-2468.7$

$-717.75$

\begin{tabular}{lll}
86.91 & -36.81 & -36.695 \\
\hline & 0.001037 &
\end{tabular}

10.001037

-36.695
0

0
1

Total lb/h

130000164146

$567369 \quad 435075 \quad 126494$

5800

$5800 \quad 5781.162$

Oxygen

Nitrogen

Argon

Carbon

Hydrogen

Carbon Monoxide

Carbon Dioxide

Methane

Acetylene

Ethylene

Ethane

Propane

Water

Sulphur

Carbonyl Sulfide

Hydrogen Sulfide

Ammonia

HydrogenChloride

Silicon Dioxide

Calcium Oxide

Benzene

Naphthalene

Hybrid Pop NREL

Sulfur Dioxide

Hydrogen Cyanide

Nitric Oxide

Methanol

Ethanol

Isopropanol

$\mathrm{N}$-Propanol

$\begin{array}{ll}0 & 0 \\ 0 & 0 \\ 0 & 0 \\ 0 & 0 \\ 0 & 0 \\ 0 & 0 \\ 0 & 0 \\ 0 & 0 \\ 0 & 0 \\ 0 & 0 \\ 0 & 0 \\ 0 & 0 \\ 0 & 0\end{array}$

0
0
0
0
0
0
0
0
0
0
0
0

0
0
0
0
0
0
0
0
0
0
0
0

0
0
0
0
0
0
0
0
0
0
0
0

$\begin{array}{ll}0 & 0 \\ 0 & 0 \\ 0 & 0 \\ 0 & 0 \\ 0 & 0 \\ 0 & 0 \\ 0 & 0 \\ 0 & 0 \\ 0 & 0 \\ 0 & 0 \\ 0 & 0 \\ 0 & 0\end{array}$

0
0
0
0
0
0
0
0
0
0
0
0

$$
\begin{aligned}
& 0 \\
& 0 \\
& 0 \\
& 0 \\
& 0 \\
& 0 \\
& 0 \\
& 0 \\
& 0 \\
& 0 \\
& 0 \\
& 0
\end{aligned}
$$$$
\begin{array}{ll}
0 & 0 \\
0 & 0 \\
0 & 0 \\
0 & 0 \\
0 & 0 \\
0 & 0 \\
0 & 0 \\
0 & 0 \\
0 & 0 \\
0 & 0 \\
0 & 0 \\
0 & 0
\end{array}
$$

$\begin{array}{lllll}0 & 10675.7 & 130000 & 164146 & 573150\end{array}$

567369

435075

26494

5800

$5800 \quad 5781.162$

$$
\begin{array}{rr}
5800 & 5781.162 \\
0 & 0
\end{array}
$$

0

0

Isobutanol

N-Butanol

1-Pentanol

0.1456
15.119

0345.543

0

2715.64
1354.882

1-Pentano

.

0
0
0
0
0
0
0
0
0
0
0
0
0
0
0

$$
\begin{aligned}
& 0 \\
& 0 \\
& 0 \\
& 0 \\
& 0 \\
& 0 \\
& 0 \\
& 0 \\
& 0 \\
& 0 \\
& 0 \\
& 0 \\
& 0 \\
& 0 \\
& 0 \\
& 0 \\
& 0 \\
& 0
\end{aligned}
$$


Stream No Stream Name Temp F Pres psia

Vapor mass fraction

Total lb/h

Flowrates in lb/h

Oxygen

Nitrogen

Argon

Carbon

Hydrogen

Carbon Monoxide

Carbon Dioxide

Methane

Acetylene

Ethylene

Ethane

Propane

Water

Sulphur

Carbonyl Sulfide

Hydrogen Sulfide

Ammonia

HydrogenChloride

Silicon Dioxide

Calcium Oxide

Benzene

Naphthalene

Hybrid Pop NREL

Sulfur Dioxide

Hydrogen Cyanide

Nitric Oxide

Methanol

Ethanol

Isopropanol

$\mathrm{N}$-Propanol

Isobutanol

N-Butanol

1-Pentanol

$\begin{array}{cc}720 & 721 \\ \text { FROM STI FROM SR REC } & \end{array}$

$1000 \quad 1000 \quad 1000$

$\begin{array}{rrr}850 & 850 & 850\end{array}$

$\begin{array}{rr}450 & 450 \\ -3053.7 & -734.35\end{array}$

11

0

$\begin{array}{rrr}1 & 1 & 1 \\ 561842 & 561842 & 135113\end{array}$

$\begin{array}{ll}0 & 0 \\ 0 & 0 \\ 0 & 0 \\ 0 & 0 \\ 0 & 0 \\ 0 & 0 \\ 0 & 0 \\ 0 & 0 \\ 0 & 0 \\ 0 & 0 \\ 0 & 0 \\ 0 & 0\end{array}$

$435348 \quad 126493.8$

561842

0
561842

135113

426729

0
0
0

0
164146

$450 \quad 860$

860
-932.53
0.98971

(36.

$\begin{array}{ccc}742 & 743 & 744 \\ \text { to GASIFIETO REBOITO MOL SIEVE }\end{array}$

$\begin{array}{rrrrrrrr}35 & 36.3953 & 366.3953 & 366.3953 & 366.3953 & 366.3953 & 366.3953 & 115.5419\end{array}$

\begin{tabular}{rr}
1 & 0.98971 \\
\hline & 164146
\end{tabular}

$-413.15-10$

35
-660.77 $\begin{array}{rrrr}35 & 35 & 35 & 1.5 \\ -152.56 & -1076.4 & -3.7509 & -681.05\end{array}$ 26729

1
73120

$\begin{array}{rr}1 & 1 \\ 18500 & 116945\end{array}$

27000

1

1

$1 \quad 0.93746$

$\begin{array}{ll}0 & 0 \\ 0 & 0 \\ 0 & 0 \\ 0 & 0 \\ 0 & 0 \\ 0 & 0 \\ 0 & 0 \\ 0 & 0 \\ 0 & 0 \\ 0 & 0 \\ 0 & 0 \\ 0 & 0\end{array}$

0
0
0
0
0
0
0
0
0
0
0
0

0
0
0
0
0
0
0
0
0
0
0
0

0
0
0
0
0
0
0
0
0
0
0
0

$\begin{array}{ll}0 & 0 \\ 0 & 0 \\ 0 & 0 \\ 0 & 0 \\ 0 & 0 \\ 0 & 0 \\ 0 & 0 \\ 0 & 0 \\ 0 & 0 \\ 0 & 0 \\ 0 & 0 \\ 0 & 0\end{array}$

426729

73120

18500

116945 
Stream No.

Stream Name

Temp F

Pres psia

Vapor mass fraction

Flowrates in $\mathrm{lb} / \mathrm{h}$

Oxygen

Nitrogen

Argon

Carbon

Hydrogen

Carbon Monoxide

Carbon Dioxide

Methane

Acetylene

Ethylene

Ethane

Propane

Water

Sulphur

Carbonyl Sulfide

Hydrogen Sulfide

Ammonia

HydrogenChloride

Silicon Dioxide

Calcium Oxide

Benzene

Naphthalene

Hybrid Pop NREL

Sulfur Dioxide

Hydrogen Cyanide

Nitric Oxide

Methano

Ethanol

Isopropanol

$\mathrm{N}$-Propano

Isobutanol

N-Butanol

1-Pentanol
$761 \quad 762$

\author{
769
}

$770 \quad 772$

$773 \quad 774$

\begin{abstract}
777
\end{abstract}
779 BFW 781

791

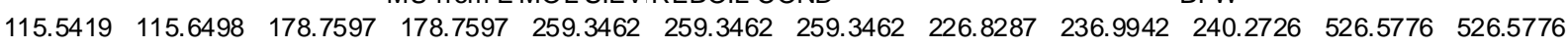

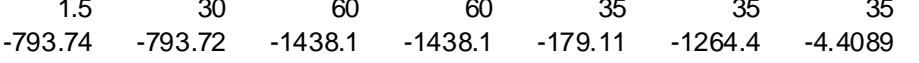
$\begin{array}{llll}0 & 0.009411 & 0.00564 & 0.001\end{array}$ $\begin{array}{rrrrr}-2922.8 & -3821.1 & -3819.2 & -60.648 & -738.52\end{array}$ $\begin{array}{rrr}0 & 0 & 0 \\ 116945 & 116945 & 213884\end{array}$ 0 $27000 \quad 190500 \quad 663.8382$ $-2922.8$ 0

-3819.2
0

0.99
10675.7

\begin{tabular}{rr}
-99 \\
\hline
\end{tabular} (1)

$\begin{array}{rr}0 & 0 \\ 0 & 0 \\ 0 & 0 \\ 0 & 0 \\ 0 & 0 \\ 0 & 0 \\ 0 & 0 \\ 0 & 0 \\ 0 & 0 \\ 0 & 0 \\ 0 & 0 \\ 0 & 0\end{array}$

$\begin{array}{ll}0 & 0 \\ 0 & 0 \\ 0 & 0 \\ 0 & 0 \\ 0 & 0 \\ 0 & 0 \\ 0 & 0 \\ 0 & 0 \\ 0 & 0 \\ 0 & 0 \\ 0 & 0 \\ 0 & 0\end{array}$

116945

116945

213884

213884

0
0
0
0
0
0
0
0
0
0
0
0

0
0
0
0
0
0
0
0
0
0
0
0

$\begin{array}{lll}0 & 0 & 0 \\ 0 & 0 & 0 \\ 0 & 0 & 0 \\ 0 & 0 & 0 \\ 0 & 0 & 0 \\ 0 & 0 & 0 \\ 0 & 0 & 0 \\ 0 & 0 & 0 \\ 0 & 0 & 0 \\ 0 & 0 & 0 \\ 0 & 0 & 0 \\ 0 & 0 & 0\end{array}$

27000

190500

$6500 \quad 663.8382$

0
437848

573293 573293

$\begin{array}{ll}0 & 0 \\ 0 & 0 \\ 0 & 0 \\ 0 & 0 \\ 0 & 0 \\ 0 & 0 \\ 0 & 0 \\ 0 & 0 \\ 0 & 0 \\ 0 & 0 \\ 0 & 0 \\ 0 & 0\end{array}$

$\begin{array}{ll}0 & 0 \\ 0 & 0 \\ 0 & 0 \\ 0 & 0 \\ 0 & 0 \\ 0 & 0 \\ 0 & 0 \\ 0 & 0 \\ 0 & 0 \\ 0 & 0 \\ 0 & 0 \\ 0 & 0\end{array}$

\begin{tabular}{|c|c|c|}
\hline 794 & 1602 & 1701 \\
\hline \multicolumn{3}{|c|}{ FUEL GASTO WWT } \\
\hline 1000 & 71.4942 & 118.317 \\
\hline 850 & 16 & 15 \\
\hline-2334.2 & -171.41 & -67250 \\
\hline 1 & 1 & 0 \\
\hline 435348 & 77146.09 & 9925413 \\
\hline
\end{tabular}

$\begin{array}{rrr}0 & 0 & 0 \\ 0 & 218.6577 & 0.0916 \\ 0 & 0 & 0 \\ 0 & 0 & 0 \\ 0 & 3434.957 & 4.1179 \\ 0 & 44032.44 & 65.1421 \\ 0 & 19273.77 & 17852.19 \\ 0 & 6844.954 & 13.669 \\ 0 & 0.0012 & 0.3676 \\ 0 & 0.2364 & 13.2064 \\ 0 & 223.0892 & 0.0647 \\ 0 & 0 & 0\end{array}$

$\begin{array}{lll}435348 & 126.0698 & 9900374\end{array}$

$\begin{array}{rrr}0 & 0 & 0 \\ 0 & 0 & 0 \\ 0 & 0 & 109.9485 \\ 0 & 10.6638 & 6979.57 \\ 0 & 0 & 0 \\ 0 & 0 & 0 \\ 0 & 0 & 0 \\ 0 & 0 & 0.2917 \\ 0 & 0 & 0.086 \\ 0 & 0 & 0 \\ 0 & 0 & 0 \\ 0 & 0.2293 & 0 \\ 0 & 0 & 0 \\ 0 & 2293.303 & 0 \\ 0 & 609.9102 & 0 \\ 0 & 0 & 0 \\ 0 & 59.8768 & 0 \\ 0 & 0 & 0 \\ 0 & 12.3067 & 0 \\ 0 & 5.6418 & 0\end{array}$




\begin{tabular}{|c|c|c|c|c|c|c|c|c|c|c|c|c|c|c|c|}
\hline Stream No. & 1702 & 1703 & 1741 & 1742 & 1743 & 1744 & 1745 & 1746 & 1747 & 1748 & 1749 & 1750 & 1751 & 1830 & 1831 \\
\hline Stream Name & & & & & & & & \multicolumn{2}{|c|}{ TO WWT } & \multicolumn{2}{|c|}{ to WWT } & TO DEARE & to SCRUB|C & eWs & \\
\hline Temp F & 118.317 & 118.317 & 253.0462 & 274.5935 & 0 & 195.4107 & 195.4109 & 209.0953 & 205.1707 & 231.2065 & 211.696 & 171.8389 & 110 & 90 & 110 \\
\hline Pres psia & 15 & 15 & 28 & 54 & 0 & 109.5 & 109.5 & 220 & 109.5 & 465 & 109.5 & 109.5 & 427.5 & 60 & 60 \\
\hline Enth MMBtu/h & -672.5 & -66577 & 0 & 0 & 0 & -15.876 & -15.876 & -39.36 & -55.236 & -18.357 & -73.593 & -121.97 & -820.73 & -26023 & -25947 \\
\hline Vapor mass fraction & 0 & 0 & 0 & 0 & 0 & 0 & 0 & 0 & 0 & 0 & 0 & 0 & 0 & 0 & 0 \\
\hline $\begin{array}{l}\text { Total lb/h } \\
\text { Flowrates in lb/h }\end{array}$ & 99254.12 & 9826158 & 0 & 0 & 0 & 2367.09 & 2367.09 & 5880.385 & 8247.476 & 2751.756 & 10999.23 & 18121.07 & 120823.2 & 3819701 & 3819701 \\
\hline Oxygen & 0 & 0 & 0 & 0 & 0 & 0 & 0 & 0 & 0 & 0 & 0 & 0 & 0 & 0 & 0 \\
\hline Nitrogen & 0.0009 & 0.0907 & 0 & 0 & 0 & 0 & 0 & 0 & 0 & 0 & 0 & 0 & 0 & 0 & 0 \\
\hline Argon & 0 & 0 & 0 & 0 & 0 & 0 & 0 & 0 & 0 & 0 & 0 & 0 & 0 & 0 & 0 \\
\hline Carbon & 0 & 0 & 0 & 0 & 0 & 0 & 0 & 0 & 0 & 0 & 0 & 0 & 0 & 0 & 0 \\
\hline Hydrogen & 0.0412 & 4.0767 & 0 & 0 & 0 & 0 & 0 & 0 & 0 & 0 & 0 & 0 & 0 & 0 & 0 \\
\hline Carbon Monoxide & 0.6514 & 64.4907 & 0 & 0 & 0 & 0 & 0 & 0 & 0 & 0 & 0 & 0 & 0 & 0 & 0 \\
\hline Carbon Dioxide & 178.5219 & 17673.67 & 0 & 0 & 0 & 0 & 0 & 0 & 0 & 0 & 0 & 0 & 0 & 0 & 0 \\
\hline Methane & 0.1367 & 13.5323 & 0 & 0 & 0 & 0 & 0 & 0 & 0 & 0 & 0 & 0 & 0 & 0 & 0 \\
\hline Acetylene & 0.0037 & 0.3639 & 0 & 0 & 0 & 0 & 0 & 0 & 0 & 0 & 0 & 0 & 0 & 0 & 0 \\
\hline Ethylene & 0.1321 & 13.0743 & 0 & 0 & 0 & 0 & 0 & 0 & 0 & 0 & 0 & 0 & 0 & 0 & 0 \\
\hline Ethane & 0.0006 & 0.0641 & 0 & 0 & 0 & 0 & 0 & 0 & 0 & 0 & 0 & 0 & 0 & 0 & 0 \\
\hline Propane & 0 & 0 & 0 & 0 & 0 & 0 & 0 & 0 & 0 & 0 & 0 & 0 & 0 & 0 & 0 \\
\hline Water & 99003.73 & 9801370 & 0 & 0 & 0 & 2367.09 & 2367.09 & 5880.385 & 8247.476 & 2751.756 & 10999.23 & 18121.07 & 120823.2 & 3819701 & 3819701 \\
\hline Sulphur & 0 & 0 & 0 & 0 & 0 & 0 & 0 & 0 & 0 & 0 & 0 & 0 & 0 & 0 & 0 \\
\hline Carbonyl Sulfide & 0 & 0 & 0 & 0 & 0 & 0 & 0 & 0 & 0 & 0 & 0 & 0 & 0 & 0 & 0 \\
\hline Hydrogen Sulfide & 1.0995 & 108.8491 & 0 & 0 & 0 & 0 & 0 & 0 & 0 & 0 & 0 & 0 & 0 & 0 & 0 \\
\hline Ammonia & 69.7957 & 6909.775 & 0 & 0 & 0 & 0 & 0 & 0 & 0 & 0 & 0 & 0 & 0 & 0 & 0 \\
\hline HydrogenChloride & 0 & 0 & 0 & 0 & 0 & 0 & 0 & 0 & 0 & 0 & 0 & 0 & 0 & 0 & 0 \\
\hline Silicon Dioxide & 0 & 0 & 0 & 0 & 0 & 0 & 0 & 0 & 0 & 0 & 0 & 0 & 0 & 0 & 0 \\
\hline Calcium Oxide & 0 & 0 & 0 & 0 & 0 & 0 & 0 & 0 & 0 & 0 & 0 & 0 & 0 & 0 & 0 \\
\hline Benzene & 0.0029 & 0.2888 & 0 & 0 & 0 & 0 & 0 & 0 & 0 & 0 & 0 & 0 & 0 & 0 & 0 \\
\hline Naphthalene & 0.0009 & 0.0851 & 0 & 0 & 0 & 0 & 0 & 0 & 0 & 0 & 0 & 0 & 0 & 0 & 0 \\
\hline Hybrid Pop NREL & 0 & 0 & 0 & 0 & 0 & 0 & 0 & 0 & 0 & 0 & 0 & 0 & 0 & 0 & 0 \\
\hline Sulfur Dioxide & 0 & 0 & 0 & 0 & 0 & 0 & 0 & 0 & 0 & 0 & 0 & 0 & 0 & 0 & 0 \\
\hline Hydrogen Cyanide & 0 & 0 & 0 & 0 & 0 & 0 & 0 & 0 & 0 & 0 & 0 & 0 & 0 & 0 & 0 \\
\hline Nitric Oxide & 0 & 0 & 0 & 0 & 0 & 0 & 0 & 0 & 0 & 0 & 0 & 0 & 0 & 0 & 0 \\
\hline Methanol & 0 & 0 & 0 & 0 & 0 & 0 & 0 & 0 & 0 & 0 & 0 & 0 & 0 & 0 & 0 \\
\hline Ethanol & 0 & 0 & 0 & 0 & 0 & 0 & 0 & 0 & 0 & 0 & 0 & 0 & 0 & 0 & 0 \\
\hline Isopropanol & 0 & 0 & 0 & 0 & 0 & 0 & 0 & 0 & 0 & 0 & 0 & 0 & 0 & 0 & 0 \\
\hline N-Propanol & 0 & 0 & 0 & 0 & 0 & 0 & 0 & 0 & 0 & 0 & 0 & 0 & 0 & 0 & 0 \\
\hline Isobutanol & 0 & 0 & 0 & 0 & 0 & 0 & 0 & 0 & 0 & 0 & 0 & 0 & 0 & 0 & 0 \\
\hline N-Butanol & 0 & 0 & 0 & 0 & 0 & 0 & 0 & 0 & 0 & 0 & 0 & 0 & 0 & 0 & 0 \\
\hline 1-Pentanol & 0 & 0 & 0 & 0 & 0 & 0 & 0 & 0 & 0 & 0 & 0 & 0 & 0 & 0 & 0 \\
\hline
\end{tabular}




\begin{tabular}{|c|c|c|c|c|c|c|c|c|c|c|c|c|c|c|c|}
\hline Stream No. & 1834 & 1835 & 1840 & 1841 & 1842 & 1843 & 1850 & 1851 & 1861 & 1862 & 1871 & 1872 & 1910 & 1931 & 1932 \\
\hline Stream Name & CWS & & CWS & & WS & & WS & & & & & & STEAM & BFW & to STM DR \\
\hline Temp F & 90 & 110 & 90 & 110 & 90 & 110 & 90 & 110 & 90 & 110 & 90 & 110 & 260 & 237 & 526.5776 \\
\hline Pres psia & 60 & 60 & 65 & 65 & 65 & 65 & 65 & 60 & 60 & 60 & 65 & 65 & 25 & 860 & 860 \\
\hline Enth MMBtu/h & -196.29 & -195.71 & -941.89 & -939.13 & -5031.6 & -5016.9 & -2485.9 & -2478.6 & -1183.8 & -1179 & -62829 & -62716 & -416.82 & -71.155 & -60.648 \\
\hline Vapor mass fraction & 0 & 0 & 0 & 0 & 0 & 0 & 0 & 0 & 0 & 0 & 0 & 0 & 1 & 0 & 0.99 \\
\hline $\begin{array}{l}\text { Total lb/h } \\
\text { Flowrates in lb/h }\end{array}$ & 28811.37 & 28811.37 & 138253.4 & 138253.4 & 738555 & 738555 & 364879 & 364879 & 173765 & 173765 & 9232755 & 9232755 & 73119.59 & 10675.7 & 10675.7 \\
\hline Oxygen & 0 & 0 & 0 & 0 & 0 & 0 & 0 & 0 & 0 & 0 & 0 & 0 & 0 & 0 & 0 \\
\hline Nitrogen & 0 & 0 & 0 & 0 & 0 & 0 & 0 & 0 & 0 & 0 & 0 & 0 & 0 & 0 & 0 \\
\hline Argon & 0 & 0 & 0 & 0 & 0 & 0 & 0 & 0 & 0 & 0 & 0 & 0 & 0 & 0 & 0 \\
\hline Carbon & 0 & 0 & 0 & 0 & 0 & 0 & 0 & 0 & 0 & 0 & 0 & 0 & 0 & 0 & 0 \\
\hline Hydrogen & 0 & 0 & 0 & 0 & 0 & 0 & 0 & 0 & 0 & 0 & 0 & 0 & 0 & 0 & 0 \\
\hline Carbon Monoxide & 0 & 0 & 0 & 0 & 0 & 0 & 0 & 0 & 0 & 0 & 0 & 0 & 0 & 0 & 0 \\
\hline Carbon Dioxide & 0 & 0 & 0 & 0 & 0 & 0 & 0 & 0 & 0 & 0 & 0 & 0 & 0 & 0 & 0 \\
\hline Methane & 0 & 0 & 0 & 0 & 0 & 0 & 0 & 0 & 0 & 0 & 0 & 0 & 0 & 0 & 0 \\
\hline Acetylene & 0 & 0 & 0 & 0 & 0 & 0 & 0 & 0 & 0 & 0 & 0 & 0 & 0 & 0 & 0 \\
\hline Ethylene & 0 & 0 & 0 & 0 & 0 & 0 & 0 & 0 & 0 & 0 & 0 & 0 & 0 & 0 & 0 \\
\hline Ethane & 0 & 0 & 0 & 0 & 0 & 0 & 0 & 0 & 0 & 0 & 0 & 0 & 0 & 0 & 0 \\
\hline Propane & 0 & 0 & 0 & 0 & 0 & 0 & 0 & 0 & 0 & 0 & 0 & 0 & 0 & 0 & 0 \\
\hline Water & 28811.37 & 28811.37 & 138253.4 & 138253.4 & 738555 & 738555 & 364879 & 364879 & 173765 & 173765 & 9232755 & 9232755 & 73119.59 & 10675.7 & 10675.7 \\
\hline Sulphur & 0 & 0 & 0 & 0 & 0 & 0 & 0 & 0 & 0 & 0 & 0 & 0 & 0 & 0 & 0 \\
\hline Carbonyl Sulfide & 0 & 0 & 0 & 0 & 0 & 0 & 0 & 0 & 0 & 0 & 0 & 0 & 0 & 0 & 0 \\
\hline Hydrogen Sulfide & 0 & 0 & 0 & 0 & 0 & 0 & 0 & 0 & 0 & 0 & 0 & 0 & 0 & 0 & 0 \\
\hline Ammonia & 0 & 0 & 0 & 0 & 0 & 0 & 0 & 0 & 0 & 0 & 0 & 0 & 0 & 0 & 0 \\
\hline HydrogenChloride & 0 & 0 & 0 & 0 & 0 & 0 & 0 & 0 & 0 & 0 & 0 & 0 & 0 & 0 & 0 \\
\hline Silicon Dioxide & 0 & 0 & 0 & 0 & 0 & 0 & 0 & 0 & 0 & 0 & 0 & 0 & 0 & 0 & 0 \\
\hline Calcium Oxide & 0 & 0 & 0 & 0 & 0 & 0 & 0 & 0 & 0 & 0 & 0 & 0 & 0 & 0 & 0 \\
\hline Benzene & 0 & 0 & 0 & 0 & 0 & 0 & 0 & 0 & 0 & 0 & 0 & 0 & 0 & 0 & 0 \\
\hline Naphthalene & 0 & 0 & 0 & 0 & 0 & 0 & 0 & 0 & 0 & 0 & 0 & 0 & 0 & 0 & 0 \\
\hline Hybrid Pop NREL & 0 & 0 & 0 & 0 & 0 & 0 & 0 & 0 & 0 & 0 & 0 & 0 & 0 & 0 & 0 \\
\hline Sulfur Dioxide & 0 & 0 & 0 & 0 & 0 & 0 & 0 & 0 & 0 & 0 & 0 & 0 & 0 & 0 & 0 \\
\hline Hydrogen Cyanide & 0 & 0 & 0 & 0 & 0 & 0 & 0 & 0 & 0 & 0 & 0 & 0 & 0 & 0 & 0 \\
\hline Nitric Oxide & 0 & 0 & 0 & 0 & 0 & 0 & 0 & 0 & 0 & 0 & 0 & 0 & 0 & 0 & 0 \\
\hline Methanol & 0 & 0 & 0 & 0 & 0 & 0 & 0 & 0 & 0 & 0 & 0 & 0 & 0 & 0 & 0 \\
\hline Ethanol & 0 & 0 & 0 & 0 & 0 & 0 & 0 & 0 & 0 & 0 & 0 & 0 & 0 & 0 & 0 \\
\hline Isopropanol & 0 & 0 & 0 & 0 & 0 & 0 & 0 & 0 & 0 & 0 & 0 & 0 & 0 & 0 & 0 \\
\hline N-Propanol & 0 & 0 & 0 & 0 & 0 & 0 & 0 & 0 & 0 & 0 & 0 & 0 & 0 & 0 & 0 \\
\hline Isobutanol & 0 & 0 & 0 & 0 & 0 & 0 & 0 & 0 & 0 & 0 & 0 & 0 & 0 & 0 & 0 \\
\hline N-Butanol & 0 & 0 & 0 & 0 & 0 & 0 & 0 & 0 & 0 & 0 & 0 & 0 & 0 & 0 & 0 \\
\hline 1-Pentanol & 0 & 0 & 0 & 0 & 0 & 0 & 0 & 0 & 0 & 0 & 0 & 0 & 0 & 0 & 0 \\
\hline
\end{tabular}




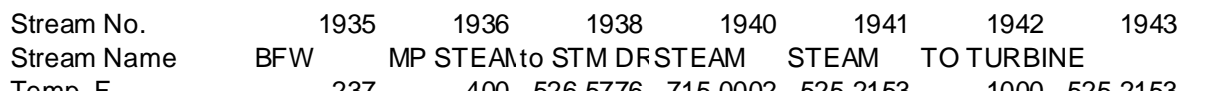

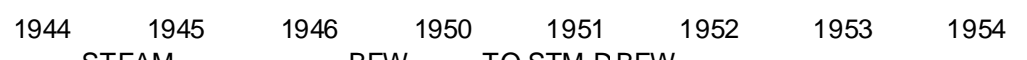

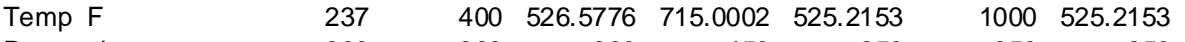
$\begin{array}{llllllll}1000 & 366.3939 & 259.3462 & 237 & 526.5776 & 237 & 526.5776 & 526.5776\end{array}$ $\begin{array}{lrrrrrrr}\text { Pres psia } & 860 & 860 & 860 & 450 & 850 & 850 & 850\end{array}$ Enth MMBtu/h
Vapor mass fraction $\begin{array}{rr}860 & 860 \\ -866.47 & -844.28 \\ 0 & 0\end{array}$

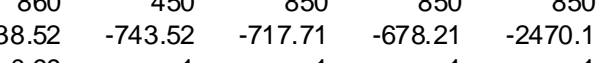
$\begin{array}{rrrrrrrr}850 & 35 & 35 & 860 & 860 & 860 & 860 & 860 \\ -2334.2 & -3.7505 & -4.4085 & -1788.5 & -1524.3 & -1094.1 & -932.53 & -932.53\end{array}$ $\begin{array}{llllllll}\text { Total Ib/h } & 130000 & 130000 & 130000 & 135112.5 & 126493.8 & 126493.8 & 435348\end{array}$

Flowrates in $\mathrm{lb} / \mathrm{h}$

Oxygen

Nitrogen

Argon

Carbon

Carbon Monoxide

Carbon Dioxide

Methane

Acetylene

Ethylene

Ethane

Propane

Water

Sulphur

Carbonyl Sulfide

Hydrogen Sulfide

Ammonia

HydrogenChloride

Silicon Dioxide

Calcium Oxide

Benzene

Naphthalene

Hybrid Pop NREL

Sulfur Dioxide

Hydrogen Cyanide

Nitric Oxide

Methanol

Ethanol

Isopropanol

N-Propanol

Isobutanol

N-Butanol

1-Pentanol

$\begin{array}{llllll}0 & 0 & 0 & 0 & 0 & 0 \\ 0 & 0 & 0 & 0 & 0 & 0 \\ 0 & 0 & 0 & 0 & 0 & 0 \\ 0 & 0 & 0 & 0 & 0 & 0 \\ 0 & 0 & 0 & 0 & 0 & 0 \\ 0 & 0 & 0 & 0 & 0 & 0 \\ 0 & 0 & 0 & 0 & 0 & 0 \\ 0 & 0 & 0 & 0 & 0 & 0 \\ 0 & 0 & 0 & 0 & 0 & 0 \\ 0 & 0 & 0 & 0 & 0 & 0 \\ 0 & 0 & 0 & 0 & 0 & 0 \\ 0 & 0 & 0 & 0 & 0 & 0\end{array}$

$\begin{array}{lllllll}130000 & 130000 & 130000 & 135112.5 & 126493.8 & 126493.8\end{array}$

$\begin{array}{llll}0 & 0 & 0 & 0 \\ 0 & 0 & 0 & 0 \\ 0 & 0 & 0 & 0 \\ 0 & 0 & 0 & 0 \\ 0 & 0 & 0 & 0 \\ 0 & 0 & 0 & 0 \\ 0 & 0 & 0 & 0 \\ 0 & 0 & 0 & 0 \\ 0 & 0 & 0 & 0 \\ 0 & 0 & 0 & 0 \\ 0 & 0 & 0 & 0 \\ 0 & 0 & 0 & 0\end{array}$

$\begin{array}{lll}0 & 0.98971 & 0.98971\end{array}$

$\begin{array}{lllll}0 & 0 & 0 & 0 & 0 \\ 0 & 0 & 0 & 0 & 0 \\ 0 & 0 & 0 & 0 & 0 \\ 0 & 0 & 0 & 0 & 0 \\ 0 & 0 & 0 & 0 & 0 \\ 0 & 0 & 0 & 0 & 0 \\ 0 & 0 & 0 & 0 & 0 \\ 0 & 0 & 0 & 0 & 0 \\ 0 & 0 & 0 & 0 & 0 \\ 0 & 0 & 0 & 0 & 0 \\ 0 & 0 & 0 & 0 & 0 \\ 0 & 0 & 0 & 0 & 0 \\ 0 & 0 & 0 & 0 & 0 \\ 0 & 0 & 0 & 0 & 0 \\ 0 & 0 & 0 & 0 & 0 \\ 0 & 0 & 0 & 0 & 0 \\ 0 & 0 & 0 & 0 & 0 \\ 0 & 0 & 0 & 0 & 0 \\ 0 & 0 & 0 & 0 & 0 \\ 0 & 0 & 0 & 0 & 0\end{array}$

0
0
0
0
0
0
0
0
0
0
0
0
0
0
0
0
0
0
0
0

$\begin{array}{llllll}435348 & 663.7736 & 663.7736 & 268328.3 & 268328.3\end{array}$

0

0

$\begin{array}{lll}0 & 0 & 0 \\ 0 & 0 & 0 \\ 0 & 0 & 0 \\ 0 & 0 & 0 \\ 0 & 0 & 0 \\ 0 & 0 & 0 \\ 0 & 0 & 0 \\ 0 & 0 & 0 \\ 0 & 0 & 0 \\ 0 & 0 & 0 \\ 0 & 0 & 0 \\ 0 & 0 & 0 \\ 0 & 0 & 0 \\ 0 & 0 & 0 \\ 0 & 0 & 0 \\ 0 & 0 & 0 \\ 0 & 0 & 0 \\ 0 & 0 & 0 \\ 0 & 0 & 0 \\ 0 & 0 & 0\end{array}$

$\begin{array}{ll}0 & 0 \\ 0 & 0 \\ 0 & 0 \\ 0 & 0 \\ 0 & 0 \\ 0 & 0 \\ 0 & 0 \\ 0 & 0 \\ 0 & 0 \\ 0 & 0 \\ 0 & 0 \\ 0 & 0 \\ 0 & 0 \\ 0 & 0 \\ 0 & 0 \\ 0 & 0 \\ 0 & 0 \\ 0 & 0 \\ 0 & 0 \\ 0 & 0\end{array}$

164146

\begin{tabular}{|c|c|}
\hline \multirow{2}{*}{\multicolumn{2}{|c|}{$\begin{array}{l}0 \\
0\end{array}$}} \\
\hline & \\
\hline 0 & \\
\hline 0 & \\
\hline 0 & \\
\hline 0 & \\
\hline 0 & \\
\hline 0 & \\
\hline 0 & \\
\hline 0 & \\
\hline 0 & \\
\hline 0 & \\
\hline 0 & \\
\hline 0 & \\
\hline 0 & \\
\hline 0 & \\
\hline $\begin{array}{l}0 \\
0\end{array}$ & \\
\hline $\begin{array}{l}0 \\
0\end{array}$ & \\
\hline
\end{tabular}

0
0
0
0
0
0
0
0
0
0
0
0
0
0
0
0
0
0

0
0
0
0
0
0
0
0
0
0
0
0
0
0
0
0
0




\begin{tabular}{|c|c|c|c|c|c|c|c|c|c|c|c|c|c|c|c|}
\hline Stream No. & 1834 & 1835 & 1840 & 1841 & 1842 & 1843 & 1850 & 1851 & 1861 & 1862 & 1871 & 1872 & 1910 & 1931 & 1932 \\
\hline Stream Name & CWS & & cWs & & WS & & WS & & & & & & STEAM & BFW $\quad t$ & to STM DR \\
\hline Temp F & 90 & 110 & 90 & 110 & 90 & 110 & 90 & 110 & 90 & 110 & 90 & 110 & 260 & 237 & 526.5776 \\
\hline Pres psia & 60 & 60 & 65 & 65 & 65 & 65 & 65 & 60 & 60 & 60 & 65 & 65 & 25 & 860 & 860 \\
\hline Enth MMBtu/h & -196.29 & -195.71 & -941.89 & -939.13 & -5031.6 & -5016.9 & -2485.9 & -2478.6 & -1183.8 & -1179 & -62829 & -62716 & -416.82 & -71.155 & -60.648 \\
\hline Vapor mass fraction & 0 & 0 & 0 & 0 & 0 & 0 & 0 & 0 & 0 & 0 & 0 & 0 & 1 & 0 & 0.99 \\
\hline $\begin{array}{l}\text { Total lb/h } \\
\text { Flowrates in lb/h }\end{array}$ & 28811.37 & 28811.37 & 138253.4 & 138253.4 & 738555 & 738555 & 364879 & 364879 & 173765 & 173765 & 9232755 & 9232755 & 73119.59 & 10675.7 & 10675.7 \\
\hline Oxygen & 0 & 0 & 0 & 0 & 0 & 0 & 0 & 0 & 0 & 0 & 0 & 0 & 0 & 0 & 0 \\
\hline Nitrogen & 0 & 0 & 0 & 0 & 0 & 0 & 0 & 0 & 0 & 0 & 0 & 0 & 0 & 0 & 0 \\
\hline Argon & 0 & 0 & 0 & 0 & 0 & 0 & 0 & 0 & 0 & 0 & 0 & 0 & 0 & 0 & 0 \\
\hline Carbon & 0 & 0 & 0 & 0 & 0 & 0 & 0 & 0 & 0 & 0 & 0 & 0 & 0 & 0 & 0 \\
\hline Hydrogen & 0 & 0 & 0 & 0 & 0 & 0 & 0 & 0 & 0 & 0 & 0 & 0 & 0 & 0 & 0 \\
\hline Carbon Monoxide & 0 & 0 & 0 & 0 & 0 & 0 & 0 & 0 & 0 & 0 & 0 & 0 & 0 & 0 & 0 \\
\hline Carbon Dioxide & 0 & 0 & 0 & 0 & 0 & 0 & 0 & 0 & 0 & 0 & 0 & 0 & 0 & 0 & 0 \\
\hline Methane & 0 & 0 & 0 & 0 & 0 & 0 & 0 & 0 & 0 & 0 & 0 & 0 & 0 & 0 & 0 \\
\hline Acetylene & 0 & 0 & 0 & 0 & 0 & 0 & 0 & 0 & 0 & 0 & 0 & 0 & 0 & 0 & 0 \\
\hline Ethylene & 0 & 0 & 0 & 0 & 0 & 0 & 0 & 0 & 0 & 0 & 0 & 0 & 0 & 0 & 0 \\
\hline Ethane & 0 & 0 & 0 & 0 & 0 & 0 & 0 & 0 & 0 & 0 & 0 & 0 & 0 & 0 & 0 \\
\hline Propane & 0 & 0 & 0 & 0 & 0 & 0 & 0 & 0 & 0 & 0 & 0 & 0 & 0 & 0 & 0 \\
\hline Water & 28811.37 & 28811.37 & 138253.4 & 138253.4 & 738555 & 738555 & 364879 & 364879 & 173765 & 173765 & 9232755 & 9232755 & 73119.59 & 10675.7 & 10675.7 \\
\hline Sulphur & 0 & 0 & 0 & 0 & 0 & 0 & 0 & 0 & 0 & 0 & 0 & 0 & 0 & 0 & 0 \\
\hline Carbonyl Sulfide & 0 & 0 & 0 & 0 & 0 & 0 & 0 & 0 & 0 & 0 & 0 & 0 & 0 & 0 & 0 \\
\hline Hydrogen Sulfide & 0 & 0 & 0 & 0 & 0 & 0 & 0 & 0 & 0 & 0 & 0 & 0 & 0 & 0 & 0 \\
\hline Ammonia & 0 & 0 & 0 & 0 & 0 & 0 & 0 & 0 & 0 & 0 & 0 & 0 & 0 & 0 & 0 \\
\hline HydrogenChloride & 0 & 0 & 0 & 0 & 0 & 0 & 0 & 0 & 0 & 0 & 0 & 0 & 0 & 0 & 0 \\
\hline Silicon Dioxide & 0 & 0 & 0 & 0 & 0 & 0 & 0 & 0 & 0 & 0 & 0 & 0 & 0 & 0 & 0 \\
\hline Calcium Oxide & 0 & 0 & 0 & 0 & 0 & 0 & 0 & 0 & 0 & 0 & 0 & 0 & 0 & 0 & 0 \\
\hline Benzene & 0 & 0 & 0 & 0 & 0 & 0 & 0 & 0 & 0 & 0 & 0 & 0 & 0 & 0 & 0 \\
\hline Naphthalene & 0 & 0 & 0 & 0 & 0 & 0 & 0 & 0 & 0 & 0 & 0 & 0 & 0 & 0 & 0 \\
\hline Hybrid Pop NREL & 0 & 0 & 0 & 0 & 0 & 0 & 0 & 0 & 0 & 0 & 0 & 0 & 0 & 0 & 0 \\
\hline Sulfur Dioxide & 0 & 0 & 0 & 0 & 0 & 0 & 0 & 0 & 0 & 0 & 0 & 0 & 0 & 0 & 0 \\
\hline Hydrogen Cyanide & 0 & 0 & 0 & 0 & 0 & 0 & 0 & 0 & 0 & 0 & 0 & 0 & 0 & 0 & 0 \\
\hline Nitric Oxide & 0 & 0 & 0 & 0 & 0 & 0 & 0 & 0 & 0 & 0 & 0 & 0 & 0 & 0 & 0 \\
\hline Methanol & 0 & 0 & 0 & 0 & 0 & 0 & 0 & 0 & 0 & 0 & 0 & 0 & 0 & 0 & 0 \\
\hline Ethanol & 0 & 0 & 0 & 0 & 0 & 0 & 0 & 0 & 0 & 0 & 0 & 0 & 0 & 0 & 0 \\
\hline Isopropanol & 0 & 0 & 0 & 0 & 0 & 0 & 0 & 0 & 0 & 0 & 0 & 0 & 0 & 0 & 0 \\
\hline N-Propanol & 0 & 0 & 0 & 0 & 0 & 0 & 0 & 0 & 0 & 0 & 0 & 0 & 0 & 0 & 0 \\
\hline Isobutanol & 0 & 0 & 0 & 0 & 0 & 0 & 0 & 0 & 0 & 0 & 0 & 0 & 0 & 0 & 0 \\
\hline N-Butanol & 0 & 0 & 0 & 0 & 0 & 0 & 0 & 0 & 0 & 0 & 0 & 0 & 0 & 0 & 0 \\
\hline 1-Pentanol & 0 & 0 & 0 & 0 & 0 & 0 & 0 & 0 & 0 & 0 & 0 & 0 & 0 & 0 & 0 \\
\hline
\end{tabular}




\section{Appendix B. Heat and Material Balance for the MSW Case}


Figure B-1 Process Flow Diagram for the MSW Case

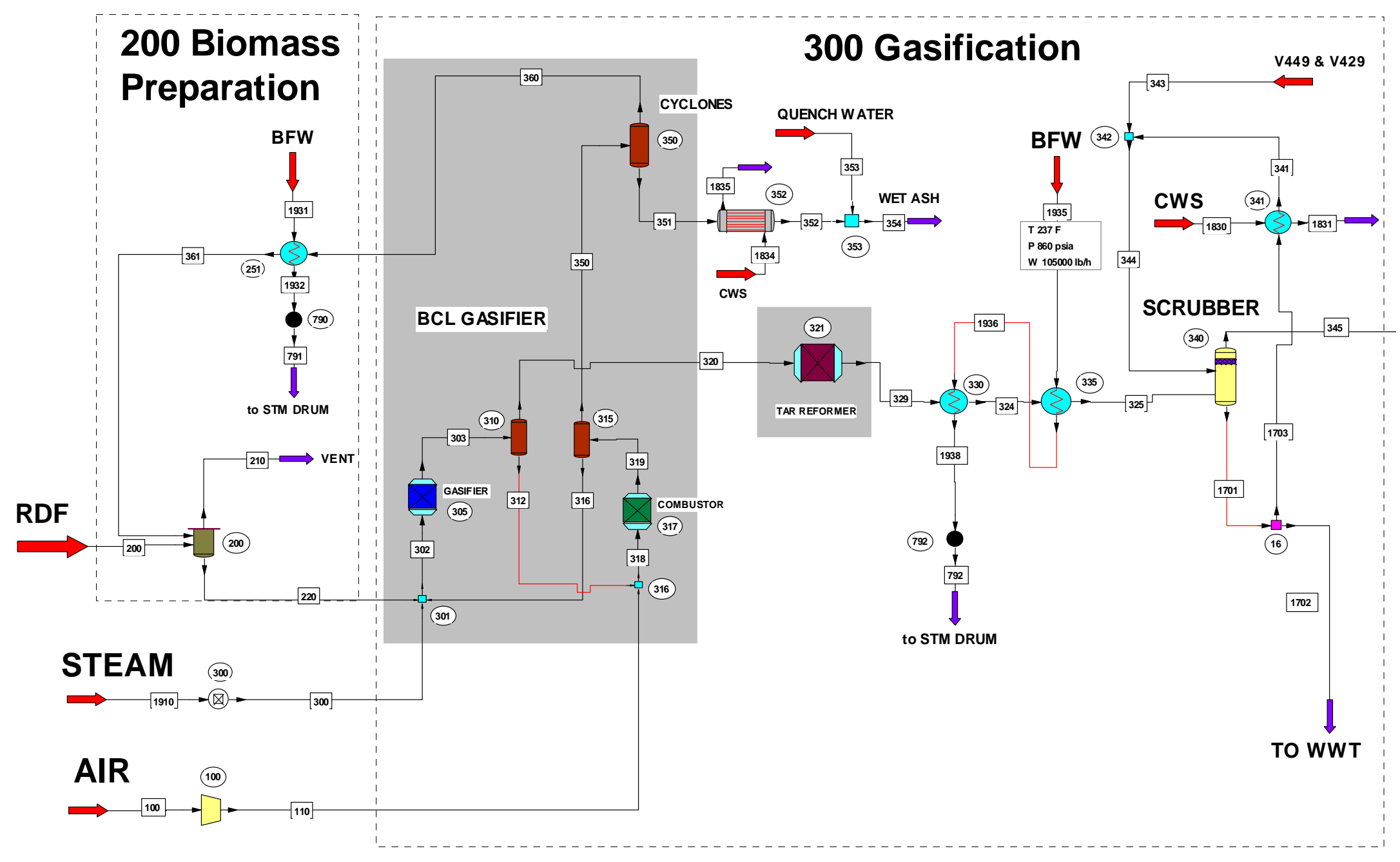


Figure B-1 Process Flow Diagram for the MSW Case (cont.)

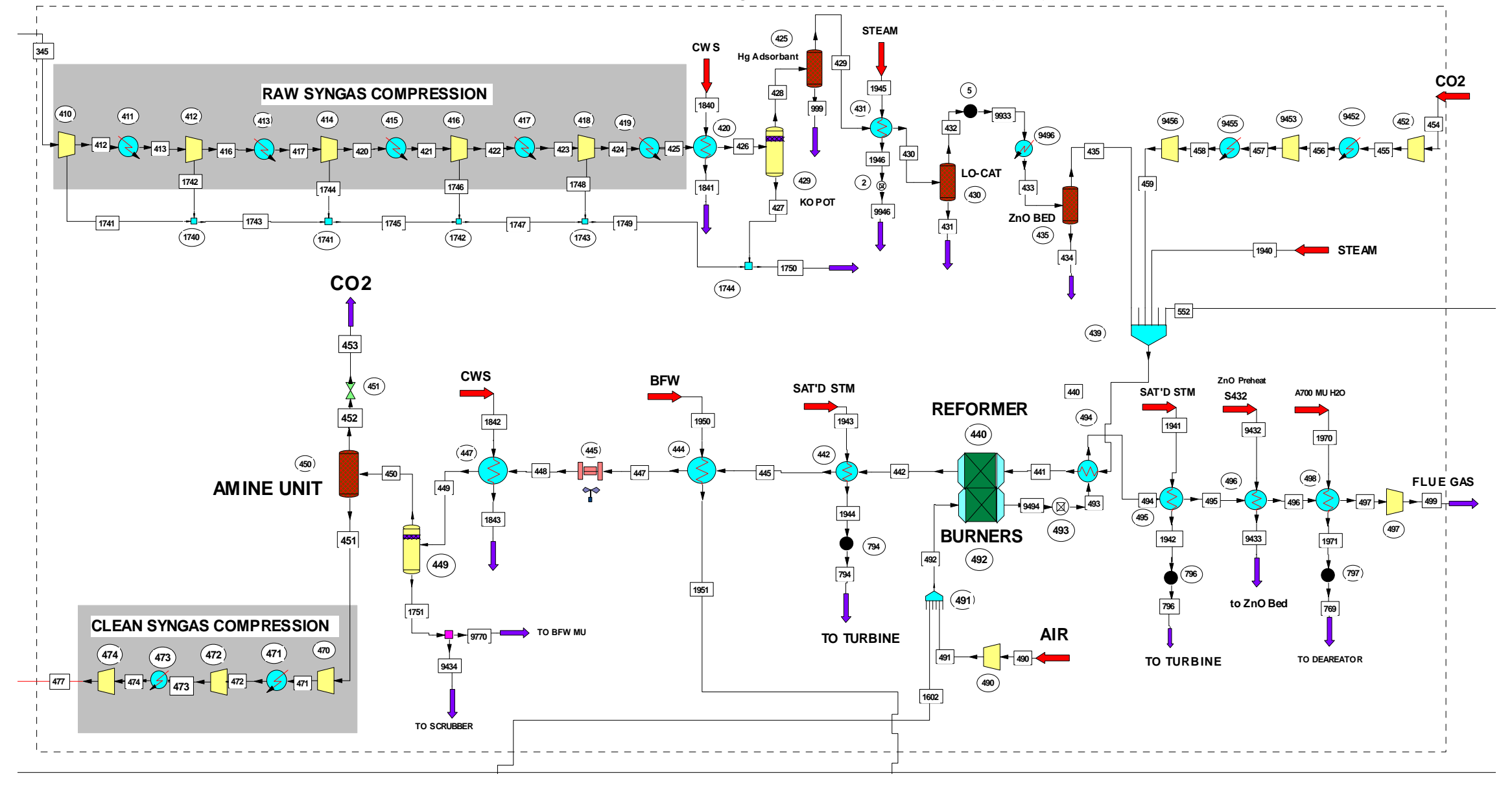


Figure B-1 Process Flow Diagram for the MSW Case (cont.)

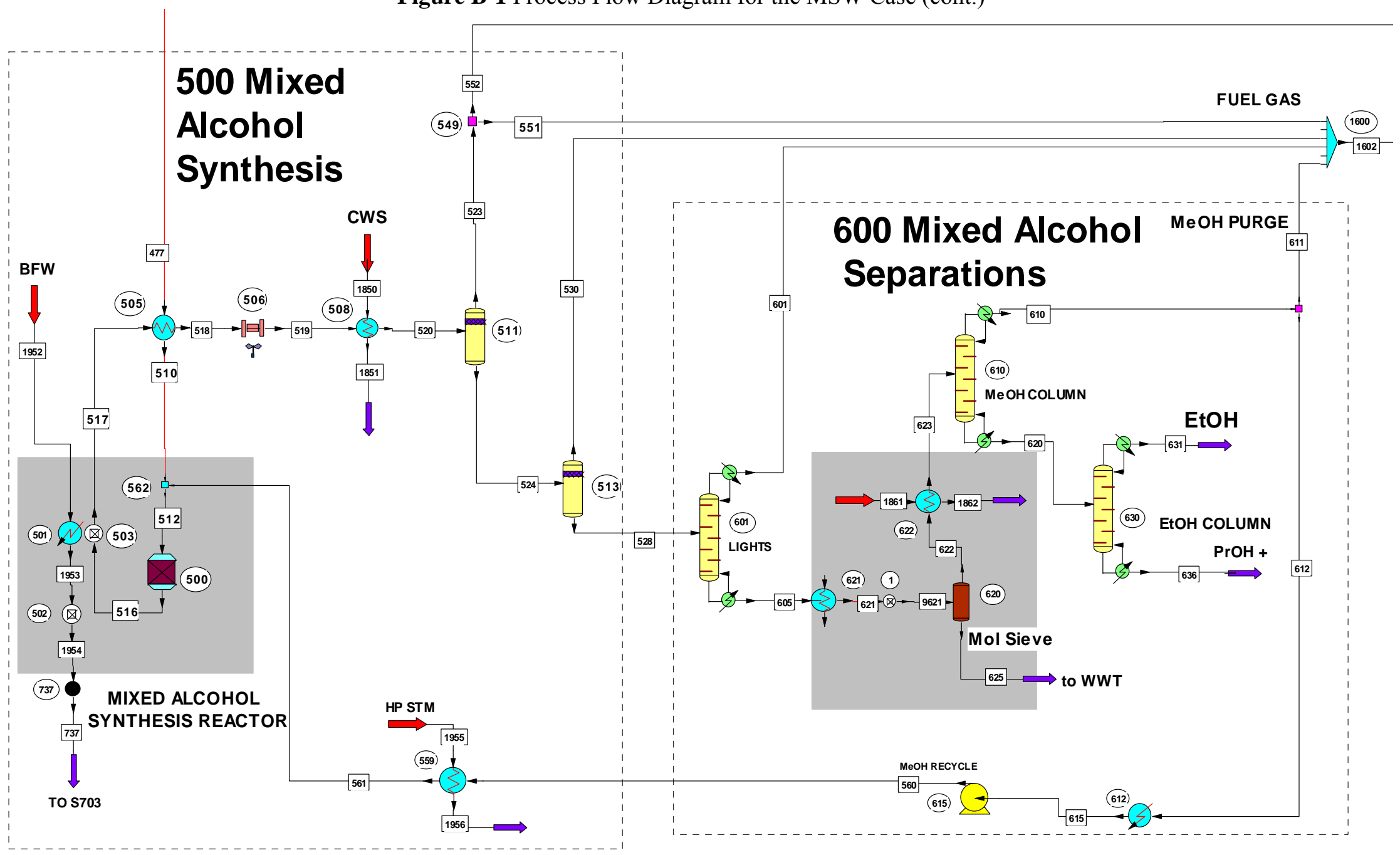


Figure B-1 Process Flow Diagram for the MSW Case (cont.)

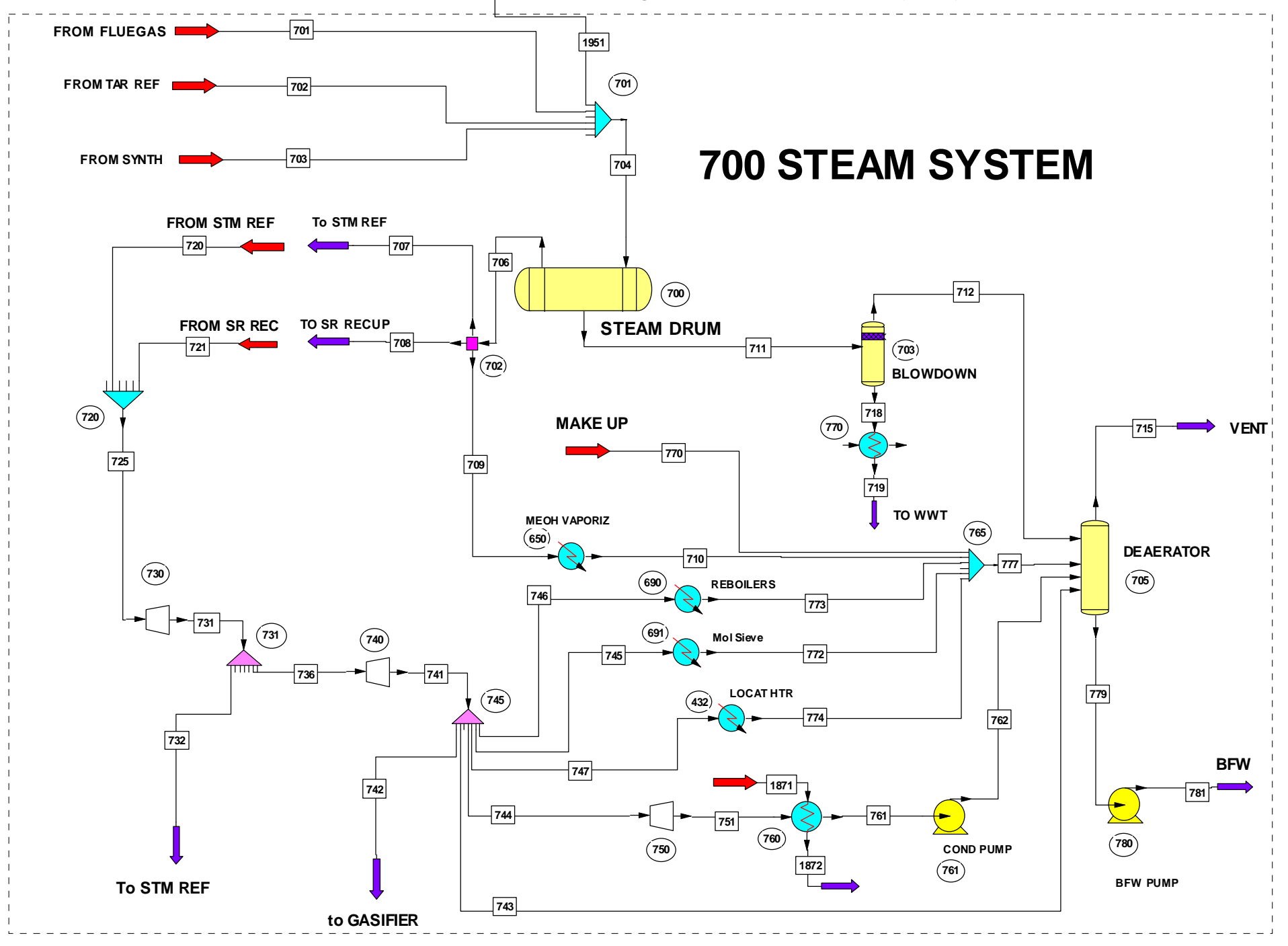


Table B-1 Steam Results for the MSW Case

\begin{tabular}{|c|c|c|c|c|c|c|c|c|c|c|c|c|c|c|c|}
\hline $\begin{array}{l}\text { Stream No. } \\
\text { Stream Name }\end{array}$ & 100 & 110 & 200 & 210 & 220 & 300 & 302 & 303 & 312 & 316 & 318 & Syngas ${ }^{319}$ & 320 & 324 & 325 \\
\hline Temp F & 60 & 172.5231 & 60 & 304.7456 & 220 & 259.3482 & 1661.5451 & 1511 & 1511 & 1730 & 1432.019 & 1730 & 1511 & 462.4696 & 249.0378 \\
\hline Pres psia & 14.696 & 30 & 25 & 23 & 23 & 35 & 23 & 23 & 23 & 23 & 23 & 23 & 23 & 19 & 18 \\
\hline Enth MMBtu/h & -71.027 & -50.695 & -1853 & -1746.7 & -721.28 & -417.08 & -11319 & -11320 & -10777 & -10181 & -10827 & -10828 & -543.26 & -583.54 & -601.47 \\
\hline Vapor mass fraction & 0.99137 & 1 & 0 & 1 & 0 & 1 & 1 & 1 & 1 & 0 & 1 & 1 & 1 & 1 & 1 \\
\hline $\begin{array}{l}\text { Total Ib/h } \\
\text { Fowrates in lb/h }\end{array}$ & 555001 & 555001 & 367435.188 & 795754 & 204130.703 & 73119.7656 & 6277250.5 & 6277251 & 6096737 & 6000000 & 6651737.5 & 6651739.5 & 180513.516 & 180513.109 & 180513.109 \\
\hline Oxygen & 125921.063 & 125921.063 & 0 & 16851.8438 & 0 & 0 & 0 & 32906.8516 & 32906.8516 & 0 & 158828 & 16851.8438 & 0 & 0 & 0 \\
\hline Nitrogen & 410968.219 & 410968.219 & 0 & 410945 & 0 & 0 & 0 & 0 & 0 & 0 & 410968.219 & 410945 & 0 & 392.5347 & 392.5347 \\
\hline Argon & 7009.0005 & 7009.0005 & 0 & 7009.0005 & 0 & 0 & 0 & 0 & 0 & 0 & 7009.0005 & 7009.0005 & 0 & 0 & 0 \\
\hline Carbon & 0 & 0 & 0 & 0 & 0 & 0 & 0 & 40123.7344 & 40123.7344 & 0 & 40123.7305 & 0.0015 & 0 & 0 & 0 \\
\hline Hydrogen & 0 & 0 & 0 & 0.0005 & 0 & 0 & 0 & 5699.1343 & 4416.0098 & 0 & 4416.0098 & 0.0005 & 1283.1241 & 5422.354 & 5422.354 \\
\hline Carbon Monoxide & 0 & 0 & 0 & 0 & 0 & 0 & 0 & 39389.8164 & 0 & 0 & 0 & 0 & 39389.8164 & 67260.8438 & 67260.8438 \\
\hline Carbon Dioxide & 273.6321 & 273.6321 & 0 & 147297.656 & 0 & 0 & 0 & 14855.46 & 0 & 0 & 273.6321 & 147297.656 & 14855.46 & 14855.46 & 14855.46 \\
\hline Methane & 0 & 0 & 0 & 0 & 0 & 0 & 0 & 9054.3818 & 0 & 0 & 0 & 0 & 9054.3818 & 7243.5059 & 7243.5059 \\
\hline Acetylene & 0 & 0 & 0 & 0 & 0 & 0 & 0 & 398.3862 & 0 & 0 & 0 & 0 & 398.3862 & 199.1931 & 199.1931 \\
\hline Ethylene & 0 & 0 & 0 & 0 & 0 & 0 & 0 & 17005.373 & 0 & 0 & 0 & 0 & 17005.373 & 8502.6865 & 8502.6865 \\
\hline Ethane & 0 & 0 & 0 & 0 & 0 & 0 & 0 & 1041.9557 & 0 & 0 & 0 & 0 & 1041.9557 & 104.1956 & 104.1956 \\
\hline Propane & 0 & 0 & 0 & 0 & 0 & 0 & 0 & 0 & 0 & 0 & 0 & 0 & 0 & 0 & 0 \\
\hline Water & 10828.5596 & 10828.5596 & 183717.547 & 213600 & 20413.0703 & 73119.7656 & 93532.8359 & 93532.8359 & 0 & 0 & 10828.5596 & 50295.5 & 93532.8359 & 75607.2188 & 75607.2188 \\
\hline Sulphur & 0 & 0 & 0 & 0 & 0 & 0 & 0 & 0 & 0 & 0 & 0 & 0 & 0 & 0 & 0 \\
\hline Carbonyl Sulfide & 0 & 0 & 0 & 0 & 0 & 0 & 0 & 0 & 0 & 0 & 0 & 0 & 0 & 0 & 0 \\
\hline Hydrogen Sulfide & 0 & 0 & 0 & 0 & 0 & 0 & 0 & 397.3538 & 0 & 0 & 0 & 0 & 397.3538 & 397.3538 & 397.3538 \\
\hline Ammonia & 0 & 0 & 0 & 0 & 0 & 0 & 0 & 681.8284 & 0 & 0 & 0 & 0 & 681.8284 & 204.5485 & 204.5485 \\
\hline HydrogenChloride & 0 & 0 & 0 & 0 & 0 & 0 & 0 & 0 & 0 & 0 & 0 & 0 & 0 & 0 & 0 \\
\hline Silicon Dioxide & 0 & 0 & 0 & 0 & 0 & 0 & 6000000 & 6000000 & 6000000 & 6000000 & 6000000 & 6000000 & 0 & 0 & 0 \\
\hline Calcium Oxide & 0 & 0 & 0 & 0 & 0 & 0 & 0 & 19290.3516 & 19290.3516 & 0 & 19290.3496 & 19290.4082 & 0 & 0 & 0 \\
\hline Benzene & 0 & 0 & 0 & 0 & 0 & 0 & 0 & 718.251 & 0 & 0 & 0 & 0 & 718.251 & 215.4753 & 215.4753 \\
\hline Naphthal ene & 0 & 0 & 0 & 0 & 0 & 0 & 0 & 2154.7529 & 0 & 0 & 0 & 0 & 2154.7529 & 107.7377 & 107.7377 \\
\hline Hybrid Poplar Ch & 0 & 0 & 0 & 0 & 0 & 0 & 0 & 0 & 0 & 0 & 0 & 0 & 0 & 0 & 0 \\
\hline Sulfur Dioxide & 0 & 0 & 0 & 0 & 0 & 0 & 0 & 0 & 0 & 0 & 0 & 0 & 0 & 0 & 0 \\
\hline Hydrogen Cyanide & 0 & 0 & 0 & 0 & 0 & 0 & 0 & 0 & 0 & 0 & 0 & 0 & 0 & 0 & 0 \\
\hline Nitric Oxide & 0 & 0 & 0 & 50.1734 & 0 & 0 & 0 & 0 & 0 & 0 & 0 & 50.1734 & 0 & 0 & 0 \\
\hline Methanol & 0 & 0 & 0 & 0 & 0 & 0 & 0 & 0 & 0 & 0 & 0 & 0 & 0 & 0 & 0 \\
\hline Ethanol & 0 & 0 & 0 & 0 & 0 & 0 & 0 & 0 & 0 & 0 & 0 & 0 & 0 & 0 & 0 \\
\hline Isopropanol & 0 & 0 & 0 & 0 & 0 & 0 & 0 & 0 & 0 & 0 & 0 & 0 & 0 & 0 & 0 \\
\hline N-Propanol & 0 & 0 & 0 & 0 & 0 & 0 & 0 & 0 & 0 & 0 & 0 & 0 & 0 & 0 & 0 \\
\hline Isobutanol & 0 & 0 & 0 & 0 & 0 & 0 & 0 & 0 & 0 & 0 & 0 & 0 & 0 & 0 & 0 \\
\hline N-Butanol & 0 & 0 & 0 & 0 & 0 & 0 & 0 & 0 & 0 & 0 & 0 & 0 & 0 & 0 & 0 \\
\hline 1-Pentanol & 0 & 0 & 0 & 0 & 0 & 0 & 0 & 0 & 0 & 0 & 0 & 0 & 0 & 0 & \\
\hline RDF & 0 & & 17625 & 0 & 3717625 & 0 & 717625 & 0 & 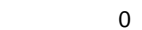 & 0 & 0 & & 0 & 0 & \\
\hline
\end{tabular}




\begin{tabular}{|c|c|c|c|c|c|c|c|c|c|c|c|c|c|c|c|}
\hline Stream No. & 329 & 341 & 343 & 344 & 345 & 350 & 351 & 352 & 353 & 354 & 360 & 361 & 412 & 413 & 416 \\
\hline Stream Name & & & $V 449 \& V 429$ & & & & ASH & & QUENCH WA & WET ASH & & & & & \\
\hline Temp F & 1383 & 110 & 110 & 109.9994 & 118.6996 & 1730 & 1730 & 300 & 60 & 212.0109 & 1730 & 1450 & 253.7146 & 140 & 272.2724 \\
\hline Pres psia & 20 & 15 & 415 & 15 & 15 & 23 & 23 & 23 & 14.7 & 14.7 & 23 & 23 & 28 & 28 & 54 \\
\hline Enth MMBtu/h & -498.12 & -66129 & -253.51 & -66383 & -254.29 & -647.04 & -86.863 & -93.021 & -5.1321 & -98.153 & -560.18 & -614.95 & -247.14 & -254 & -246.15 \\
\hline Vapor mass fraction & 1 & 0.0046978 & 0 & 0.0046794 & 1 & 1 & 0 & 0 & 0 & 0.33858 & 1 & 1 & 1 & 0.99327 & 1 \\
\hline Total Ib/h & 180513.109 & 9760903 & 37319.6602 & 9798222 & 118171.734 & 651740 & 19290.4082 & 19290.4082 & 750.0001 & 20040.4082 & 632449 & 632449 & 118171.734 & 118171.734 & 118171.734 \\
\hline $\begin{array}{l}\text { Powrates in lb/h } \\
\text { Oxygen }\end{array}$ & 0 & 0 & 0 & 0 & 0 & 16851.8438 & 0 & 0 & 0 & 0 & 16851.8438 & 16851.8438 & & 0 & \\
\hline Nitrogen & 392.5347 & 0.2354 & 0 & 0.2354 & 392.5323 & 410945 & 0 & 0 & 0 & 0 & 410945 & $\begin{array}{r}10031.0400 \\
410945\end{array}$ & 392.5323 & 392.5323 & $\begin{array}{r}0 \\
392.5323\end{array}$ \\
\hline Argon & 0 & 0 & 0 & 0 & 0 & 7009.0005 & 0 & 0 & 0 & 0 & 7009.0005 & 7009.0005 & 0 & 0 & 0 \\
\hline Carbon & 0 & 0 & 0 & 0 & 0 & 0.0015 & 0.0015 & 0.0015 & 0 & 0.0015 & 0 & 0 & 0 & 0 & 0 \\
\hline Hydrogen & 5422.354 & 4.7008 & 0 & 4.7007 & 5422.3066 & 0.0005 & 0 & 0 & 0 & 0 & 0.0005 & 0.0005 & 5422.3066 & 5422.3066 & 5422.3066 \\
\hline Carbon Monoxide & 67260.8438 & 59.6037 & 0 & 59.6037 & 67260.2344 & 0 & 0 & 0 & 0 & 0 & 0 & 0 & 67260.2344 & 67260.2344 & 67260.2344 \\
\hline Carbon Dioxide & 14855.46 & 29694.6875 & 0 & 29694.6914 & 14548.0752 & 147297.656 & 0 & 0 & 0 & 0 & 147297.656 & 147297.656 & 14548.0752 & 14548.0752 & 14548.0752 \\
\hline Methane & 7243.5059 & 10.1854 & 0 & 10.1854 & 7243.4019 & 0 & 0 & 0 & 0 & 0 & 0 & 0 & 7243.4019 & 7243.4019 & 7243.4019 \\
\hline Acetylene & 199.1931 & 0.2868 & 0 & 0.2868 & 199.1902 & 0 & 0 & 0 & 0 & 0 & 0 & 0 & 199.1902 & 199.1902 & 199.1902 \\
\hline Ethylene & 8502.6865 & 37.3303 & 0 & 37.3303 & 8502.3047 & 0 & 0 & 0 & 0 & 0 & 0 & 0 & 8502.3047 & 8502.3047 & 8502.3047 \\
\hline Ethane & 104.1956 & 0.1556 & 0 & 0.1556 & 104.194 & 0 & 0 & 0 & 0 & 0 & 0 & 0 & 104.194 & 104.194 & 104.194 \\
\hline Propane & 0 & 0 & 0 & 0 & 0 & 0 & 0 & 0 & 0 & 0 & 0 & 0 & 0 & 0 & 0 \\
\hline Water & 75607.2188 & 9716314 & 37319.6602 & 9753634 & 13727.6865 & 50295.5 & 0 & 0 & 750.0001 & 750.0001 & 50295.5 & 50295.5 & 13727.6865 & 13727.6865 & 13727.6865 \\
\hline Sulphur & 0 & 0 & 0 & 0 & 0 & 0 & 0 & 0 & 0 & 0 & 0 & 0 & 0 & 0 & 0 \\
\hline Carbonyl Sulfide & 0 & 0 & 0 & 0 & 0 & 0 & 0 & 0 & 0 & 0 & 0 & 0 & 0 & 0 & 0 \\
\hline Hydrogen Sulfide & 397.3538 & 956.1025 & 0 & 956.1025 & 387.4926 & 0 & 0 & 0 & 0 & 0 & 0 & 0 & 387.4926 & 387.4926 & 387.4926 \\
\hline Ammonia & 204.5485 & 13825.0391 & 0 & 13825.0391 & 61.1072 & 0 & 0 & 0 & 0 & 0 & 0 & 0 & 61.1072 & 61.1072 & 61.1072 \\
\hline HydrogenChloride & 0 & 0 & 0 & 0 & 0 & 0 & 0 & 0 & 0 & 0 & 0 & 0 & 0 & 0 & 0 \\
\hline Silicon Dioxide & 0 & 0 & 0 & 0 & 0 & 0 & 0 & 0 & 0 & 0 & 0 & 0 & 0 & 0 & 0 \\
\hline Calcium Oxide & 0 & 0 & 0 & 0 & 0 & 19290.4082 & 19290.4082 & 19290.4082 & 0 & 19290.4082 & 0 & 0 & 0 & 0 & 0 \\
\hline Benzene & 215.4753 & 0.4609 & 0 & 0.4609 & 215.4706 & 0 & 0 & 0 & 0 & 0 & 0 & 0 & 215.4706 & 215.4706 & 215.4706 \\
\hline Naphthalene & 107.7377 & 0.1397 & 0 & 0.1397 & 107.7363 & 0 & 0 & 0 & 0 & 0 & 0 & 0 & 107.7363 & 107.7363 & 107.7363 \\
\hline Hybrid Poplar Ch & 0 & 0 & 0 & 0 & 0 & 0 & 0 & 0 & 0 & 0 & 0 & 0 & 0 & 0 & 0 \\
\hline Sulfur Dioxide & 0 & 0 & 0 & 0 & 0 & 0 & 0 & 0 & 0 & 0 & 0 & 0 & 0 & 0 & 0 \\
\hline Hydrogen Cyanide & 0 & 0 & 0 & 0 & 0 & 0 & 0 & 0 & 0 & 0 & 0 & 0 & 0 & 0 & 0 \\
\hline Nitric Oxide & 0 & 0 & 0 & 0 & 0 & 50.1734 & 0 & 0 & 0 & 0 & 50.1734 & 50.1734 & 0 & 0 & 0 \\
\hline Methanol & 0 & 0 & 0 & 0 & 0 & 0 & 0 & 0 & 0 & 0 & 0 & 0 & 0 & 0 & 0 \\
\hline Ethanol & 0 & 0 & 0 & 0 & 0 & 0 & 0 & 0 & 0 & 0 & 0 & 0 & 0 & 0 & 0 \\
\hline Isopropanol & 0 & 0 & 0 & 0 & 0 & 0 & 0 & 0 & 0 & 0 & 0 & 0 & 0 & 0 & 0 \\
\hline N-Propanol & 0 & 0 & 0 & 0 & 0 & 0 & 0 & 0 & 0 & 0 & 0 & 0 & 0 & 0 & 0 \\
\hline Isobutanol & 0 & 0 & 0 & 0 & 0 & 0 & 0 & 0 & 0 & 0 & 0 & 0 & 0 & 0 & 0 \\
\hline N-Butanol & 0 & 0 & 0 & 0 & 0 & 0 & 0 & 0 & 0 & 0 & 0 & 0 & 0 & 0 & 0 \\
\hline 1-Pentanol & 0 & 0 & 0 & 0 & 0 & 0 & 0 & 0 & 0 & 0 & 0 & 0 & 0 & 0 & 0 \\
\hline $\mathrm{RDF}$ & 0 & 0 & 0 & 0 & 0 & 0 & 0 & 0 & 0 & 0 & 0 & 0 & 0 & 0 & 0 \\
\hline
\end{tabular}




\begin{tabular}{|c|c|c|c|c|c|c|c|c|c|c|c|c|c|c|c|}
\hline $\begin{array}{l}\text { Stream No. } \\
\text { Stream Name }\end{array}$ & 417 & 420 & 421 & 422 & 423 & 424 & 425 & 426 & 427 & 428 & 429 & 430 & 431 & 432 & 433 \\
\hline Temp F & 140 & 195.4259 & 140 & 209.108 & 140 & 231.2095 & 140 & 110 & 110 & 110 & 110 & 120 & 120 & 120 & 707 \\
\hline Pres psia & 54 & 109.5 & 109.5 & 220 & 220 & 465 & 465 & 465 & 465 & 465 & 455 & 455 & 445 & 445 & 445 \\
\hline Enth MMBtu/h & -260.68 & -239.67 & -251.46 & -214.38 & -223.94 & -201.82 & -211.25 & -213.28 & -35.361 & -177.92 & -177.91 & -177.43 & -0.10025 & -177.36 & -148.05 \\
\hline Vapor mass fraction & 0.9376 & 1 & 0.92429 & 1 & 0.94641 & 1 & 0.95643 & 0.95175 & 0 & 1 & 1 & 1 & 0 & 1 & 1 \\
\hline $\begin{array}{l}\text { Total Ib/h } \\
\text { Fowrates in lb/h }\end{array}$ & 118171.734 & 116309.711 & 116309.711 & 112006.781 & 112006.781 & 109992.469 & 109992.469 & 109992.469 & 5306.8062 & 104685.656 & 104685.656 & 104685.656 & 61.0737 & 104624.586 & 104624.586 \\
\hline Oxygen & 0 & 0 & 0 & 0 & 0 & 0 & 0 & 0 & 0 & 0 & 0 & 0 & 0 & 0 & 0 \\
\hline Nitrogen & 392.5323 & 392.5323 & 392.5323 & 392.5323 & 392.5323 & 392.5323 & 392.5323 & 392.5323 & 0.0018 & 392.5304 & 392.5304 & 392.5304 & 0 & 392.5304 & 392.5304 \\
\hline Argon & 0 & 0 & 0 & 0 & 0 & 0 & 0 & 0 & 0 & 0 & 0 & 0 & 0 & 0 & 0 \\
\hline Carbon & 0 & 0 & 0 & 0 & 0 & 0 & 0 & 0 & 0 & 0 & 0 & 0 & 0 & 0 & 0 \\
\hline Hydrogen & 5422.3066 & 5422.3066 & 5422.3066 & 5422.3066 & 5422.3066 & 5422.3066 & 5422.3066 & 5422.3066 & 0.0108 & 5422.2959 & 5422.2959 & 5422.2959 & 0 & 5422.2959 & 5422.2959 \\
\hline Carbon Monoxide & 67260.2344 & 67260.2344 & 67260.2344 & 67260.2344 & 67260.2344 & 67260.2344 & 67260.2344 & 67260.2344 & 0.3159 & 67259.9141 & 67259.9141 & 67259.9141 & 0 & 67259.9141 & 67259.9141 \\
\hline Carbon Dioxide & 14548.0752 & 14548.0742 & 14548.0742 & 14548.0723 & 14548.0723 & 14548.0723 & 14548.0723 & 14548.0723 & 1.7083 & 14546.3652 & 14546.3652 & 14546.3652 & 0 & 14546.3652 & 14546.3652 \\
\hline Methane & 7243.4019 & 7243.4019 & 7243.4019 & 7243.4019 & 7243.4019 & 7243.4019 & 7243.4019 & 7243.4019 & 0.1385 & 7243.2627 & 7243.2627 & 7243.2627 & 0 & 7243.2627 & 7243.2627 \\
\hline Acetylene & 199.1902 & 199.1902 & 199.1902 & 199.1902 & 199.1902 & 199.1902 & 199.1902 & 199.1902 & 0.0265 & 199.1637 & 199.1637 & 199.1637 & 0 & 199.1637 & 199.1637 \\
\hline Ethylene & 8502.3047 & 8502.3047 & 8502.3047 & 8502.3037 & 8502.3037 & 8502.3037 & 8502.3037 & 8502.3037 & 0.703 & 8501.6016 & 8501.6016 & 8501.6016 & 0 & 8501.6016 & 8501.6016 \\
\hline Ethane & 104.194 & 104.194 & 104.194 & 104.194 & 104.194 & 104.194 & 104.194 & 104.194 & 0.0125 & 104.1815 & 104.1815 & 104.1815 & 0 & 104.1815 & 104.1815 \\
\hline Propane & 0 & 0 & 0 & 0 & 0 & 0 & 0 & 0 & 0 & 0 & 0 & 0 & 0 & 0 & 0 \\
\hline Water & 13727.6865 & 11865.6709 & 11865.6709 & 7562.7437 & 7562.7437 & 5548.4297 & 5548.4297 & 5548.4297 & 5209.1787 & 339.2523 & 339.2523 & 339.2523 & 0 & 339.2523 & 339.2523 \\
\hline Sulphur & 0 & 0 & 0 & 0 & 0 & 0 & 0 & 0 & 0 & 0 & 0 & 0 & 0 & 0 & 0 \\
\hline Carbonyl Sulfide & 0 & 0 & 0 & 0 & 0 & 0 & 0 & 0 & 0 & 0 & 0 & 0 & 0 & 0 & 0 \\
\hline Hydrogen Sulfide & 387.4926 & 387.4926 & 387.4926 & 387.4925 & 387.4925 & 387.4925 & 387.4925 & 387.4925 & 0.1328 & 387.3598 & 387.3598 & 387.3598 & 0 & 387.3598 & 387.3598 \\
\hline Ammonia & 61.1072 & 61.1072 & 61.1072 & 61.1072 & 61.1072 & 61.1072 & 61.1072 & 61.1072 & 0.0335 & 61.0737 & 61.0737 & 61.0737 & 61.0737 & 0 & 0 \\
\hline HydrogenChloride & 0 & 0 & 0 & 0 & 0 & 0 & 0 & 0 & 0 & 0 & 0 & 0 & 0 & 0 & 0 \\
\hline Silicon Dioxide & 0 & 0 & 0 & 0 & 0 & 0 & 0 & 0 & 0 & 0 & 0 & 0 & 0 & 0 & 0 \\
\hline Calcium Oxide & 0 & 0 & 0 & 0 & 0 & 0 & 0 & 0 & 0 & 0 & 0 & 0 & 0 & 0 & 0 \\
\hline Benzene & 215.4706 & 215.4706 & 215.4706 & 215.4706 & 215.4706 & 215.4706 & 215.4706 & 215.4706 & 5.2171 & 210.2535 & 210.2535 & 210.2535 & 0 & 210.2535 & 210.2535 \\
\hline Naphthal ene & 107.7363 & 107.7363 & 107.7363 & 107.7363 & 107.7363 & 107.7363 & 107.7363 & 107.7363 & 89.3262 & 18.4101 & 18.4101 & 18.4101 & 0 & 18.4101 & 18.4101 \\
\hline Hybrid Poplar Ch & 0 & 0 & 0 & 0 & 0 & 0 & 0 & 0 & 0 & 0 & 0 & 0 & 0 & 0 & 0 \\
\hline Sulfur Dioxide & 0 & 0 & 0 & 0 & 0 & 0 & 0 & 0 & 0 & 0 & 0 & 0 & 0 & 0 & 0 \\
\hline Hydrogen Cyanide & 0 & 0 & 0 & 0 & 0 & 0 & 0 & 0 & 0 & 0 & 0 & 0 & 0 & 0 & 0 \\
\hline Nitric Oxide & 0 & 0 & 0 & 0 & 0 & 0 & 0 & 0 & 0 & 0 & 0 & 0 & 0 & 0 & 0 \\
\hline Methanol & 0 & 0 & 0 & 0 & 0 & 0 & 0 & 0 & 0 & 0 & 0 & 0 & 0 & 0 & 0 \\
\hline Ethanol & 0 & 0 & 0 & 0 & 0 & 0 & 0 & 0 & 0 & 0 & 0 & 0 & 0 & 0 & 0 \\
\hline Isopropanol & 0 & 0 & 0 & 0 & 0 & 0 & 0 & 0 & 0 & 0 & 0 & 0 & 0 & 0 & 0 \\
\hline N-Propanol & 0 & 0 & 0 & 0 & 0 & 0 & 0 & 0 & 0 & 0 & 0 & 0 & 0 & 0 & 0 \\
\hline Isobutanol & 0 & 0 & 0 & 0 & 0 & 0 & 0 & 0 & 0 & 0 & 0 & 0 & 0 & 0 & 0 \\
\hline N-Butanol & 0 & 0 & 0 & 0 & 0 & 0 & 0 & 0 & 0 & 0 & 0 & 0 & 0 & 0 & 0 \\
\hline 1-Pentanol & 0 & 0 & 0 & 0 & 0 & 0 & 0 & 0 & 0 & 0 & 0 & 0 & 0 & 0 & 0 \\
\hline RDF & 0 & 0 & 0 & 0 & 0 & 0 & 0 & 0 & 0 & 0 & 0 & 0 & 0 & 0 & 0 \\
\hline
\end{tabular}




\begin{tabular}{|c|c|c|c|c|c|c|c|c|c|c|c|c|c|c|c|}
\hline $\begin{array}{l}\text { Stream No. } \\
\text { Stream Name }\end{array}$ & 434 & 435 & 440 & 441 & 442 & 445 & 447 & 448 & 449 & 450 & 451 & $\mathrm{CO} 2$ & 453 & 454 & 455 \\
\hline Temp F & 707 & 707 & 468.9732 & 900 & 1652 & 1155.3776 & 300.0074 & 150 & 110 & 110 & 120 & 120 & 57.2347 & 60 & 316.1526 \\
\hline Pres psia & 682 & 682 & 450 & 445 & 430 & 430 & 430 & 430 & 427.5 & 427.5 & 422.5 & 422.5 & 22 & 22 & 100 \\
\hline Enth MMBtu/h & -0.04066 & -147.95 & -1847 & -1752.4 & -1485.8 & -1606.4 & -1853.9 & -1950.4 & -1963.4 & -1116.4 & -318.22 & -798.47 & -798.47 & -762.12 & -751.25 \\
\hline Vapor mass fraction & 1 & 1 & 1 & 1 & 1 & 1 & 0.88387 & 0.77007 & 0.76623 & 1 & 1 & 0.99634 & 0.99895 & 1 & 1 \\
\hline $\begin{array}{l}\text { Total Ib/h } \\
\text { Fowrates in lb/h }\end{array}$ & 387.3598 & 104237.227 & 533428 & 533428 & 533428 & 533428 & 533428 & 533428 & 533428 & 408726.344 & 201888.734 & 206837.609 & 206837.609 & 198045 & 198045 \\
\hline Oxygen & 0 & 0 & 0 & 0 & 0 & 0 & 0 & 0 & 0 & 0 & 0 & 0 & 0 & 0 & 0 \\
\hline Nitrogen & 0 & 392.5304 & 965.5877 & 965.5877 & 956.4749 & 956.4749 & 956.4749 & 956.4749 & 956.4749 & 956.4749 & 956.4749 & 0 & 0 & 0 & 0 \\
\hline Argon & 0 & 0 & 0 & 0 & 0 & 0 & 0 & 0 & 0 & 0 & 0 & 0 & 0 & 0 & 0 \\
\hline Carbon & 0 & 0 & 0 & 0 & 0 & 0 & 0 & 0 & 0 & 0 & 0 & 0 & 0 & 0 & 0 \\
\hline Hydrogen & 0 & 5422.2959 & 10511.9482 & 10511.9482 & 14833.0586 & 14833.0586 & 14833.0586 & 14833.0586 & 14833.0586 & 14833.0576 & 14833.0576 & 0 & 0 & 0 & 0 \\
\hline Carbon Monoxide & 0 & 67259.9141 & 128707.758 & 128707.758 & 176995.125 & 176995.125 & 176995.125 & 176995.125 & 176995.125 & 176995.125 & 176995.125 & 0 & 0 & 0 & 0 \\
\hline Carbon Dioxide & 0 & 14546.3652 & 233360.594 & 233360.594 & 207796.297 & 207796.297 & 207796.297 & 207796.297 & 207796.297 & 207796.297 & 2077.9683 & 205718.328 & 205718.328 & 198045 & 198045 \\
\hline Methane & 0 & 7243.2627 & 14122.8584 & 14122.8584 & 7008.3682 & 7008.3682 & 7008.3682 & 7008.3682 & 7008.3682 & 7008.3682 & 7008.3682 & 0 & 0 & 0 & 0 \\
\hline Acetylene & 0 & 199.1637 & 199.1642 & 199.1642 & 0.0011 & 0.0011 & 0.0011 & 0.0011 & 0.0011 & 0.0011 & 0.0011 & 0 & 0 & 0 & 0 \\
\hline Ethylene & 0 & 8501.6016 & 8501.7246 & 8501.7246 & 0.2139 & 0.2139 & 0.2139 & 0.2139 & 0.2139 & 0.2139 & 0.2139 & 0 & 0 & 0 & 0 \\
\hline Ethane & 0 & 104.1815 & 376.0543 & 376.0543 & 0.4389 & 0.4389 & 0.4389 & 0.4389 & 0.4389 & 0.4389 & 0.4389 & 0 & 0 & 0 & 0 \\
\hline Propane & 0 & 0 & 0 & 0 & 0 & 0 & 0 & 0 & 0 & 0 & 0 & 0 & 0 & 0 & 0 \\
\hline Water & 0 & 339.2523 & 135551.422 & 135551.422 & 125820.68 & 125820.68 & 125820.68 & 125820.68 & 125820.68 & 1119.2845 & 0 & 1119.2845 & 1119.2869 & 0 & 0 \\
\hline Sulphur & 0 & 0 & 0 & 0 & 0 & 0 & 0 & 0 & 0 & 0 & 0 & 0 & 0 & 0 & 0 \\
\hline Carbonyl Sulfide & 0 & 0 & 0 & 0 & 0 & 0 & 0 & 0 & 0 & 0 & 0 & 0 & 0 & 0 & 0 \\
\hline Hydrogen Sulfide & 387.3598 & 0 & 0 & 0 & 0 & 0 & 0 & 0 & 0 & 0 & 0 & 0 & 0 & 0 & 0 \\
\hline Ammonia & 0 & 0 & 5.8146 & 5.8146 & 16.797 & 16.797 & 16.797 & 16.797 & 16.797 & 16.797 & 16.797 & 0 & 0 & 0 & 0 \\
\hline HydrogenChloride & 0 & 0 & 0 & 0 & 0 & 0 & 0 & 0 & 0 & 0 & 0 & 0 & 0 & 0 & 0 \\
\hline Silicon Dioxide & 0 & 0 & 0 & 0 & 0 & 0 & 0 & 0 & 0 & 0 & 0 & 0 & 0 & 0 & 0 \\
\hline Calcium Oxide & 0 & 0 & 0 & 0 & 0 & 0 & 0 & 0 & 0 & 0 & 0 & 0 & 0 & 0 & 0 \\
\hline Benzene & 0 & 210.2535 & 210.2535 & 210.2535 & 0 & 0 & 0 & 0 & 0 & 0 & 0 & 0 & 0 & 0 & 0 \\
\hline Naphthalene & 0 & 18.4101 & 18.4101 & 18.4101 & 0 & 0 & 0 & 0 & 0 & 0 & 0 & 0 & 0 & 0 & 0 \\
\hline Hybrid Poplar Ch & 0 & 0 & 0 & 0 & 0 & 0 & 0 & 0 & 0 & 0 & 0 & 0 & 0 & 0 & 0 \\
\hline Sulfur Dioxide & 0 & 0 & 0 & 0 & 0 & 0 & 0 & 0 & 0 & 0 & 0 & 0 & 0 & 0 & 0 \\
\hline Hydrogen Cyanide & 0 & 0 & 0.0371 & 0.0371 & 0.2021 & 0.2021 & 0.2021 & 0.2021 & 0.2021 & 0.2021 & 0.2021 & 0 & 0 & 0 & 0 \\
\hline Nitric Oxide & 0 & 0 & 0 & 0 & 0 & 0 & 0 & 0 & 0 & 0 & 0 & 0 & 0 & 0 & 0 \\
\hline Methanol & 0 & 0 & 316.2478 & 316.2478 & 0.0746 & 0.0746 & 0.0746 & 0.0746 & 0.0746 & 0.0746 & 0.0746 & 0 & 0 & 0 & 0 \\
\hline Ethanol & 0 & 0 & 506.4705 & 506.4705 & 0.0001 & 0.0001 & 0.0001 & 0.0001 & 0.0001 & 0.0001 & 0.0001 & 0 & 0 & 0 & 0 \\
\hline Isopropanol & 0 & 0 & 0 & 0 & 0 & 0 & 0 & 0 & 0 & 0 & 0 & 0 & 0 & 0 & 0 \\
\hline N-Propanol & 0 & 0 & 55.838 & 55.838 & 0 & 0 & 0 & 0 & 0 & 0 & 0 & 0 & 0 & 0 & 0 \\
\hline Isobutanol & 0 & 0 & 0 & 0 & 0 & 0 & 0 & 0 & 0 & 0 & 0 & 0 & 0 & 0 & 0 \\
\hline N-Butanol & 0 & 0 & 12.14 & 12.14 & 0 & 0 & 0 & 0 & 0 & 0 & 0 & 0 & 0 & 0 & 0 \\
\hline 1-Pentanol & 0 & 0 & 5.6754 & 5.6754 & 0 & 0 & 0 & 0 & 0 & 0 & 0 & 0 & 0 & 0 & 0 \\
\hline $\mathrm{RDF}$ & 0 & 0 & 0 & 0 & 0 & 0 & 0 & 0 & 0 & 0 & 0 & 0 & 0 & 0 & 0 \\
\hline
\end{tabular}




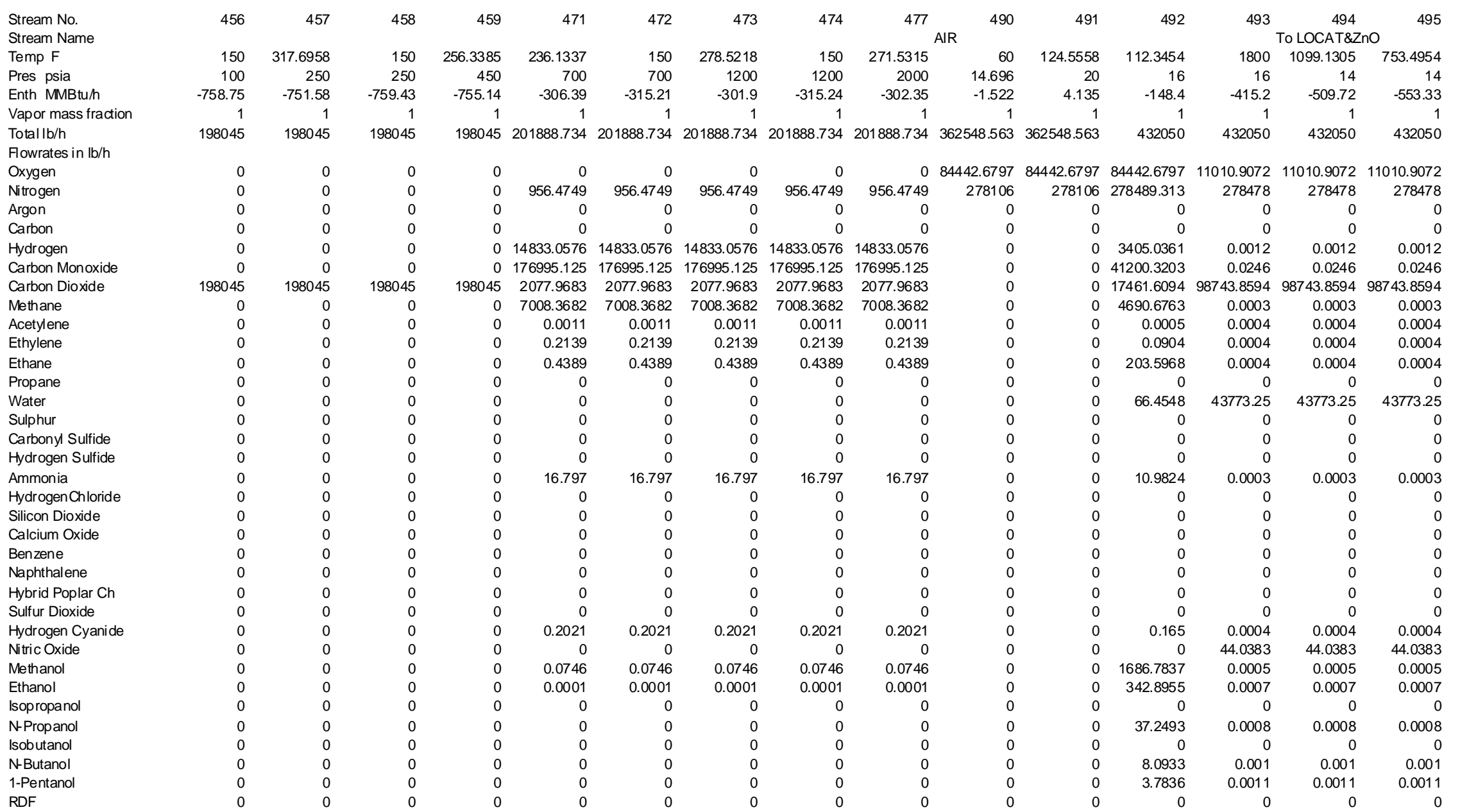




\begin{tabular}{|c|c|c|c|c|c|c|c|c|c|c|c|c|c|c|c|}
\hline Stream No. & 496 & 497 & 499 & 510 & 512 & 516 & 517 & 518 & 519 & 520 & 523 & 524 & 528 & 530 & 551 \\
\hline Stream Name & FLUE GAS & & & & & & GAS OUT & & & & & TO WWT & & & \\
\hline Temp F & 510.6381 & 280 & 297.8182 & 450 & 451.0915 & 570 & 570 & 384.1223 & 150 & 110 & 110.2502 & 110.2502 & 110.2502 & 110.2502 & 110.2502 \\
\hline Pres psia & 14 & 14 & 15 & 1995 & 1995 & 1995 & 1995 & 1990 & 1980 & 1975 & 1975 & 1975 & 1975 & 1975 & 1975 \\
\hline Enth MMBtu/h & -582.63 & -609.5 & -607.45 & -283.68 & -308.14 & -429.72 & -429.72 & -448.39 & -487.36 & -492.79 & -333.89 & -158.9 & -158.9 & 0 & -133.56 \\
\hline Vapor mass fraction & 1 & 1 & 1 & 1 & 1 & 1 & 1 & 1 & 0.77735 & 0.76051 & 1 & 0 & 0 & 1 & 1 \\
\hline $\begin{array}{l}\text { Total Ib/h } \\
\text { Fowrates in Ib/h }\end{array}$ & 432050 & 432050 & 432050 & 201888.734 & 210582.625 & 210584.063 & 210584.063 & 210584.063 & 210584.063 & 210584.063 & 160055.422 & 50528.6328 & 50528.6328 & 0 & 64022.1836 \\
\hline Oxygen & 11010.9072 & 11010.9072 & 11010.9072 & 0 & 0 & 0 & 0 & 0 & 0 & 0 & 0 & 0 & 0 & 0 & 0 \\
\hline Nitrogen & 278478 & 278478 & 278478 & 956.475 & 956.4749 & 956.4749 & 956.4749 & 956.4749 & 956.4749 & 956.4749 & 955.0955 & 1.3794 & 1.3794 & 0 & 382.0382 \\
\hline Argon & 0 & 0 & 0 & 0 & 0 & 0 & 0 & 0 & 0 & 0 & 0 & 0 & 0 & 0 & 0 \\
\hline Carbon & 0 & 0 & 0 & 0 & 0 & 0 & 0 & 0 & 0 & 0 & 0 & 0 & 0 & 0 & 0 \\
\hline Hydrogen & 0.0012 & 0.0012 & 0.0012 & 14833.0586 & 14833.0576 & 8494.6875 & 8494.6875 & 8494.6875 & 8494.6875 & 8494.6875 & 8482.7539 & 11.9344 & 11.9344 & 0 & 3393.1018 \\
\hline Carbon Monoxide & 0.0246 & 0.0246 & 0.0246 & 176995.125 & 176995.094 & 102648.141 & 102648.141 & 102648.141 & 102648.141 & 102648.141 & 102413.047 & 235.0997 & 235.0997 & 0 & 40965.2188 \\
\hline Carbon Dioxide & 98743.8594 & 98743.8594 & 98743.8594 & 2077.9683 & 2077.9683 & 38230.8398 & 38230.8398 & 38230.8398 & 38230.8398 & 38230.8398 & 34615.3867 & 3615.4543 & 3615.4543 & 0 & 13846.1553 \\
\hline Methane & 0.0003 & 0.0003 & 0.0003 & 7008.3687 & 7008.3662 & 11570.2715 & 11570.2715 & 11570.2715 & 11570.2715 & 11570.2715 & 11466 & 104.2797 & 104.2797 & 0 & 4586.3965 \\
\hline Acetylene & 0.0004 & 0.0004 & 0.0004 & 0.0011 & 0.0011 & 0.0011 & 0.0011 & 0.0011 & 0.0011 & 0.0011 & 0.001 & 0.0001 & 0.0001 & 0 & 0.0004 \\
\hline Ethylene & 0.0004 & 0.0004 & 0.0004 & 0.2139 & 0.2139 & 0.2139 & 0.2139 & 0.2139 & 0.2139 & 0.2139 & 0.2058 & 0.0081 & 0.0081 & 0 & 0.0823 \\
\hline Ethane & 0.0004 & 0.0004 & 0.0004 & 0.4389 & 0.4389 & 475.4695 & 475.4695 & 475.4695 & 475.4695 & 475.4695 & 453.1212 & 22.3483 & 22.3483 & 0 & 181.2485 \\
\hline Propane & 0 & 0 & 0 & 0 & 0 & 0 & 0 & 0 & 0 & 0 & 0 & 0 & 0 & 0 & 0 \\
\hline Water & 43773.25 & 43773.25 & 43773.25 & 0 & 0 & 5526.8784 & 5526.8784 & 5526.8784 & 5526.8784 & 5526.8784 & 166.1309 & 5360.7461 & 5360.7461 & 0 & 66.4524 \\
\hline Sulphur & 0 & 0 & 0 & 0 & 0 & 0 & 0 & 0 & 0 & 0 & 0 & 0 & 0 & 0 & 0 \\
\hline Carbonyl Sulfide & 0 & 0 & 0 & 0 & 0 & 0 & 0 & 0 & 0 & 0 & 0 & 0 & 0 & 0 & 0 \\
\hline Hydrogen Sulfide & 0 & 0 & 0 & 0 & 0 & 0 & 0 & 0 & 0 & 0 & 0 & 0 & 0 & 0 & 0 \\
\hline Ammonia & 0.0003 & 0.0003 & 0.0003 & 16.797 & 16.797 & 16.797 & 16.797 & 16.797 & 16.797 & 16.797 & 9.691 & 7.1059 & 7.1059 & 0 & 3.8764 \\
\hline HydrogenChloride & 0 & 0 & 0 & 0 & 0 & 0 & 0 & 0 & 0 & 0 & 0 & 0 & 0 & 0 & 0 \\
\hline Silicon Dioxide & 0 & 0 & 0 & 0 & 0 & 0 & 0 & 0 & 0 & 0 & 0 & 0 & 0 & 0 & 0 \\
\hline Calcium Oxide & 0 & 0 & 0 & 0 & 0 & 0 & 0 & 0 & 0 & 0 & 0 & 0 & 0 & 0 & 0 \\
\hline Benzene & 0 & 0 & 0 & 0 & 0 & 0 & 0 & 0 & 0 & 0 & 0 & 0 & 0 & 0 & 0 \\
\hline Naphthal ene & 0 & 0 & 0 & 0 & 0 & 0 & 0 & 0 & 0 & 0 & 0 & 0 & 0 & 0 & 0 \\
\hline Hybrid Poplar Ch & 0 & 0 & 0 & 0 & 0 & 0 & 0 & 0 & 0 & 0 & 0 & 0 & 0 & 0 & 0 \\
\hline Sulfur Dioxide & 0 & 0 & 0 & 0 & 0 & 0 & 0 & 0 & 0 & 0 & 0 & 0 & 0 & 0 & 0 \\
\hline Hydrogen Cyanide & 0.0004 & 0.0004 & 0.0004 & 0.2021 & 0.2021 & 0.2021 & 0.2021 & 0.2021 & 0.2021 & 0.2021 & 0.0618 & 0.1403 & 0.1403 & 0 & 0.0247 \\
\hline Nitric Oxide & 44.0383 & 44.0383 & 44.0383 & 0 & 0 & 0 & 0 & 0 & 0 & 0 & 0 & 0 & 0 & 0 & 0 \\
\hline Methanol & 0.0005 & 0.0005 & 0.0005 & 0.0746 & 8672.9873 & 10773.2061 & 10773.2061 & 10773.2061 & 10773.2061 & 10773.2061 & 527.0796 & 10246.125 & 10246.125 & 0 & 210.8318 \\
\hline Ethanol & 0.0007 & 0.0007 & 0.0007 & 0.0001 & 20.8168 & 23846.5332 & 23846.5332 & 23846.5332 & 23846.5332 & 23846.5332 & 844.1176 & 23002.4082 & 23002.4082 & 0 & 337.647 \\
\hline Isopropanol & 0 & 0 & 0 & 0 & 0 & 0 & 0 & 0 & 0 & 0 & 0 & 0 & 0 & 0 & 0 \\
\hline N-Propanol & 0.0008 & 0.0008 & 0.0008 & 0 & 0.2151 & 4936.3354 & 4936.3354 & 4936.3354 & 4936.3354 & 4936.3354 & 93.0634 & 4843.271 & 4843.271 & 0 & 37.2254 \\
\hline Isobutanol & 0 & 0 & 0 & 0 & 0 & 0 & 0 & 0 & 0 & 0 & 0 & 0 & 0 & 0 & 0 \\
\hline N-Butanol & 0.001 & 0.001 & 0.001 & 0 & 0 & 2073.8054 & 2073.8054 & 2073.8054 & 2073.8054 & 2073.8054 & 20.2333 & 2053.5718 & 2053.5718 & 0 & 8.0933 \\
\hline 1-Pentanol & 0.0011 & 0.0011 & 0.0011 & 0 & 0 & 1034.2206 & 1034.2206 & 1034.2206 & 1034.2206 & 1034.2206 & 9.459 & 1024.7612 & 1024.7612 & 0 & 3.7836 \\
\hline RDF & 0 & 0 & 0 & 0 & 0 & 0 & 0 & 0 & 0 & 0 & 0 & 0 & 0 & 0 & 0 \\
\hline
\end{tabular}




\begin{tabular}{|c|c|c|c|c|c|c|c|c|c|c|c|c|c|c|c|}
\hline Stream No. & 552 & 560 & 561 & 601 & 605 & 610 & 611 & 612 & 615 & 620 & 621 & 622 & 623 & 625 & 631 \\
\hline Stream Name & & MeOHRECY & & & & $\mathrm{MeOH}$ & MeOHPUREI & MeOH RECY & & & & Mixed $\mathrm{OH}$ & & o WWT & $\mathrm{EtOH}$ \\
\hline Temp F & 110.2502 & 167.2084 & 480 & 84.2883 & 194.8814 & 152.0141 & 152.0141 & 152.0141 & 152.0141 & 197.947 & 201.8105 & 201.8105 & 187.3736 & 201.8105 & 176.7085 \\
\hline Pres psia & 1975 & 2000 & 1995 & 23 & 26.7 & 16 & 16 & 16 & 16 & 22 & 26.7 & 23 & 23 & 23 & 16 \\
\hline Enth MMBtu/h & -200.33 & -27.353 & -24.466 & -15.934 & -139.72 & -30.493 & -3.0493 & -27.444 & -27.444 & -73.487 & -119.57 & -93.378 & -103.99 & -35.881 & -58.387 \\
\hline Vapor mass fraction & 1 & 0.0003125 & 1 & 1 & 0 & 0 & 0 & 0 & 0 & 0 & 1 & 0.67884 & $1.75 \mathrm{E}-06$ & 0 & c \\
\hline $\begin{array}{l}\text { Total Ib/h } \\
\text { Fowrates in lb/h }\end{array}$ & 96033.2734 & 8693.9443 & 8693.9443 & 4512.9829 & 46015.6484 & 9659.9404 & 965.994 & 8693.9443 & 8693.9443 & 30995.0215 & 46015.6484 & 40655 & 40655 & 5360.7534 & 23110.4844 \\
\hline Oxygen & 0 & 0 & 0 & 0 & 0 & 0 & 0 & 0 & 0 & 0 & 0 & 0 & 0 & 0 & c \\
\hline Nitrogen & 573.0573 & 0 & 0 & 1.3794 & 0 & 0 & 0 & 0 & 0 & 0 & 0 & 0 & 0 & 0 & c \\
\hline Argon & 0 & 0 & 0 & 0 & 0 & 0 & 0 & 0 & 0 & 0 & 0 & 0 & 0 & 0 & 0 \\
\hline Carbon & 0 & 0 & 0 & 0 & 0 & 0 & 0 & 0 & 0 & 0 & 0 & 0 & 0 & 0 & c \\
\hline Hydrogen & 5089.6528 & 0 & 0 & 11.9344 & 0 & 0 & 0 & 0 & 0 & 0 & 0 & 0 & 0 & 0 & c \\
\hline Carbon Monoxide & 61447.832 & 0 & 0 & 235.0997 & 0 & 0 & 0 & 0 & 0 & 0 & 0 & 0 & 0 & 0 & c \\
\hline Carbon Dioxide & 20769.2324 & 0 & 0 & 3615.4543 & 0 & 0 & 0 & 0 & 0 & 0 & 0 & 0 & 0 & 0 & c \\
\hline Methane & 6879.5952 & 0 & 0 & 104.2797 & 0 & 0 & 0 & 0 & 0 & 0 & 0 & 0 & 0 & 0 & c \\
\hline Acetylene & 0.0006 & 0 & 0 & 0.0001 & 0 & 0 & 0 & 0 & 0 & 0 & 0 & 0 & 0 & 0 & c \\
\hline Ethylene & 0.1235 & 0 & 0 & 0.0081 & 0 & 0 & 0 & 0 & 0 & 0 & 0 & 0 & 0 & 0 & c \\
\hline Ethane & 271.8728 & 0 & 0 & 22.3483 & 0 & 0 & 0 & 0 & 0 & 0 & 0 & 0 & 0 & 0 & c \\
\hline Propane & 0 & 0 & 0 & 0 & 0 & 0 & 0 & 0 & 0 & 0 & 0 & 0 & 0 & 0 & c \\
\hline Water & 99.6786 & 0 & 0 & 0.0025 & 5360.7437 & 0 & 0 & 0 & 0 & 0 & 5360.7437 & 0 & 0 & 5360.7534 & c \\
\hline Sulphur & 0 & 0 & 0 & 0 & 0 & 0 & 0 & 0 & 0 & 0 & 0 & 0 & 0 & 0 & c \\
\hline Carbonyl Sulfide & 0 & 0 & 0 & 0 & 0 & 0 & 0 & 0 & 0 & 0 & 0 & 0 & 0 & 0 & c \\
\hline Hydrogen Sulfide & 0 & 0 & 0 & 0 & 0 & 0 & 0 & 0 & 0 & 0 & 0 & 0 & 0 & 0 & c \\
\hline Ammonia & 5.8146 & 0 & 0 & 7.1059 & 0 & 0 & 0 & 0 & 0 & 0 & 0 & 0 & 0 & 0 & c \\
\hline HydrogenChloride & 0 & 0 & 0 & 0 & 0 & 0 & 0 & 0 & 0 & 0 & 0 & 0 & 0 & 0 & c \\
\hline Silicon Dioxide & 0 & 0 & 0 & 0 & 0 & 0 & 0 & 0 & 0 & 0 & 0 & 0 & 0 & 0 & c \\
\hline Calcium Oxide & 0 & 0 & 0 & 0 & 0 & 0 & 0 & 0 & 0 & 0 & 0 & 0 & 0 & 0 & c \\
\hline Benzene & 0 & 0 & 0 & 0 & 0 & 0 & 0 & 0 & 0 & 0 & 0 & 0 & 0 & 0 & c \\
\hline Naphthal ene & 0 & 0 & 0 & 0 & 0 & 0 & 0 & 0 & 0 & 0 & 0 & 0 & 0 & 0 & c \\
\hline Hybrid Poplar Ch & 0 & 0 & 0 & 0 & 0 & 0 & 0 & 0 & 0 & 0 & 0 & 0 & 0 & 0 & c \\
\hline Sulfur Dioxide & 0 & 0 & 0 & 0 & 0 & 0 & 0 & 0 & 0 & 0 & 0 & 0 & 0 & 0 & c \\
\hline Hydrogen Cyanide & 0.0371 & 0 & 0 & 0.1403 & 0 & 0 & 0 & 0 & 0 & 0 & 0 & 0 & 0 & 0 & c \\
\hline Nitric Oxide & 0 & 0 & 0 & 0 & 0 & 0 & 0 & 0 & 0 & 0 & 0 & 0 & 0 & 0 & $c$ \\
\hline Methanol & 316.2478 & 8672.9131 & 8672.9131 & 512.2948 & 9733.8291 & 9636.5713 & 963.6571 & 8672.9131 & 8672.9131 & 97.2767 & 9733.8291 & 9733.8477 & 9733.8477 & 0 & 97.166 \\
\hline Ethanol & 506.4705 & 20.8167 & 20.8167 & 2.9355 & 22999.4727 & 23.1297 & 2.313 & 20.8167 & 20.8167 & 22976.373 & 22999.4727 & 22999.502 & 22999.502 & 0 & 22964.8906 \\
\hline Isopropanol & 0 & 0 & 0 & 0 & 0 & 0 & 0 & 0 & 0 & 0 & 0 & 0 & 0 & 0 & ) \\
\hline N-Propanol & 55.838 & 0.2151 & 0.2151 & 0 & 4843.271 & 0.239 & 0.0239 & 0.2151 & 0.2151 & 4843.0371 & 4843.271 & 4843.2759 & 4843.2759 & 0 & 48.4271 \\
\hline Isobutanol & 0 & 0 & 0 & 0 & 0 & 0 & 0 & 0 & 0 & 0 & 0 & 0 & 0 & 0 & c \\
\hline N-Butanol & 12.14 & 0 & 0 & 0 & 2053.5718 & 0 & 0 & 0 & 0 & 2053.5737 & 2053.5718 & 2053.5737 & 2053.5737 & 0 & c \\
\hline 1-Pentanol & 5.6754 & 0 & 0 & 0 & 1024.7612 & 0 & 0 & 0 & 0 & 1024.7623 & 1024.7612 & 1024.7623 & 1024.7623 & 0 & c \\
\hline RDF & 0 & 0 & 0 & 0 & 0 & 0 & 0 & 0 & 0 & 0 & 0 & 0 & 0 & 0 & 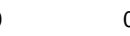 \\
\hline
\end{tabular}




\begin{tabular}{|c|c|c|c|c|c|c|c|c|c|c|c|c|c|c|c|}
\hline Stream No. & 636 & 701 & 702 & 703 & 704 & 706 & 707 & 708 & 709 & 710 & 711 & \multirow{2}{*}{\multicolumn{2}{|c|}{712 VENT }} & 718 & 719 \\
\hline Stream Name & $\mathrm{PrOH}+$ & FROM FLUEIF & $=R O M$ TAR FF & FROM SYNTH & & & STM REF 1 & O SR RECU & & & & & & \multicolumn{2}{|c|}{ TO WWT } \\
\hline Temp F & 230.6059 & 526.5776 & 526.5776 & 526.5776 & 526.5776 & 526.5776 & 526.5776 & 526.5776 & 526.5776 & 526.5776 & 526.5776 & 526.5776 & 233.9624 & 526.5776 & 150 \\
\hline Pres psia & 19 & 860 & 860 & 860 & 860 & 860 & 860 & 860 & 860 & 860 & 860 & 860 & 30 & 860 & 860 \\
\hline Enth MMBtu/h & -15.264 & -316.11 & -596.49 & -701.44 & -3042.5 & -3008.8 & -2191.7 & -792.39 & -24.683 & -27.583 & -33.679 & $-3.96 \mathrm{E}-05$ & 0 & -33.679 & -35.83 \\
\hline Vapor mass fraction & 0 & 0.99 & 0.99 & 0.99043 & 0.99009 & 1 & 1 & 1 & 1 & 0.0095721 & 0 & 1 & 1 & 0 & 0 \\
\hline $\begin{array}{l}\text { Total Ib/h } \\
\text { Fowrates in lb/h }\end{array}$ & 7884.5376 & 55644.2734 & 105000 & 123479.414 & 535571 & 530265 & 386267 & 139648 & 4350.0005 & 4350.0005 & 5305.981 & 0.007 & 0 & 5305.9736 & 5305.9736 \\
\hline Oxygen & 0 & 0 & 0 & 0 & 0 & 0 & 0 & 0 & 0 & 0 & 0 & 0 & 0 & 0 & 0 \\
\hline Nitrogen & 0 & 0 & 0 & 0 & 0 & 0 & 0 & 0 & 0 & 0 & 0 & 0 & 0 & 0 & 0 \\
\hline Argon & 0 & 0 & 0 & 0 & 0 & 0 & 0 & 0 & 0 & 0 & 0 & 0 & 0 & 0 & 0 \\
\hline Carbon & 0 & 0 & 0 & 0 & 0 & 0 & 0 & 0 & 0 & 0 & 0 & 0 & 0 & 0 & 0 \\
\hline Hydrogen & 0 & 0 & 0 & 0 & 0 & 0 & 0 & 0 & 0 & 0 & 0 & 0 & 0 & 0 & 0 \\
\hline Carbon Monoxide & 0 & 0 & 0 & 0 & 0 & 0 & 0 & 0 & 0 & 0 & 0 & 0 & 0 & 0 & 0 \\
\hline Carbon Dioxide & 0 & 0 & 0 & 0 & 0 & 0 & 0 & 0 & 0 & 0 & 0 & 0 & 0 & 0 & 0 \\
\hline Methane & 0 & 0 & 0 & 0 & 0 & 0 & 0 & 0 & 0 & 0 & 0 & 0 & 0 & 0 & 0 \\
\hline Acetylene & 0 & 0 & 0 & 0 & 0 & 0 & 0 & 0 & 0 & 0 & 0 & 0 & 0 & 0 & 0 \\
\hline Ethylene & 0 & 0 & 0 & 0 & 0 & 0 & 0 & 0 & 0 & 0 & 0 & 0 & 0 & 0 & 0 \\
\hline Ethane & 0 & 0 & 0 & 0 & 0 & 0 & 0 & 0 & 0 & 0 & 0 & 0 & 0 & 0 & 0 \\
\hline Propane & 0 & 0 & 0 & 0 & 0 & 0 & 0 & 0 & 0 & 0 & 0 & 0 & 0 & 0 & 0 \\
\hline Water & 0 & 55644.2734 & 105000 & 123479.414 & 535571 & 530265 & 386267 & 139648 & 4350.0005 & 4350.0005 & 5305.981 & 0.007 & 0 & 5305.9736 & 5305.9736 \\
\hline Sulphur & 0 & 0 & 0 & 0 & 0 & 0 & 0 & 0 & 0 & 0 & 0 & 0 & 0 & 0 & 0 \\
\hline Carbonyl Sulfide & 0 & 0 & 0 & 0 & 0 & 0 & 0 & 0 & 0 & 0 & 0 & 0 & 0 & 0 & 0 \\
\hline Hydrogen Sulfide & 0 & 0 & 0 & 0 & 0 & 0 & 0 & 0 & 0 & 0 & 0 & 0 & 0 & 0 & 0 \\
\hline Ammonia & 0 & 0 & 0 & 0 & 0 & 0 & 0 & 0 & 0 & 0 & 0 & 0 & 0 & 0 & 0 \\
\hline HydrogenChloride & 0 & 0 & 0 & 0 & 0 & 0 & 0 & 0 & 0 & 0 & 0 & 0 & 0 & 0 & 0 \\
\hline Silicon Dioxide & 0 & 0 & 0 & 0 & 0 & 0 & 0 & 0 & 0 & 0 & 0 & 0 & 0 & 0 & 0 \\
\hline Calcium Oxide & 0 & 0 & 0 & 0 & 0 & 0 & 0 & 0 & 0 & 0 & 0 & 0 & 0 & 0 & 0 \\
\hline Benzene & 0 & 0 & 0 & 0 & 0 & 0 & 0 & 0 & 0 & 0 & 0 & 0 & 0 & 0 & 0 \\
\hline Naphthalene & 0 & 0 & 0 & 0 & 0 & 0 & 0 & 0 & 0 & 0 & 0 & 0 & 0 & 0 & 0 \\
\hline Hybrid Poplar Ch & 0 & 0 & 0 & 0 & 0 & 0 & 0 & 0 & 0 & 0 & 0 & 0 & 0 & 0 & 0 \\
\hline Sulfur Dioxide & 0 & 0 & 0 & 0 & 0 & 0 & 0 & 0 & 0 & 0 & 0 & 0 & 0 & 0 & 0 \\
\hline Hydrogen Cyanide & 0 & 0 & 0 & 0 & 0 & 0 & 0 & 0 & 0 & 0 & 0 & 0 & 0 & 0 & 0 \\
\hline Nitric Oxide & 0 & 0 & 0 & 0 & 0 & 0 & 0 & 0 & 0 & 0 & 0 & 0 & 0 & 0 & 0 \\
\hline Methanol & 0.1108 & 0 & 0 & 0 & 0 & 0 & 0 & 0 & 0 & 0 & 0 & 0 & 0 & 0 & 0 \\
\hline Ethanol & 11.4814 & 0 & 0 & 0 & 0 & 0 & 0 & 0 & 0 & 0 & 0 & 0 & 0 & 0 & 0 \\
\hline Isopropanol & 0 & 0 & 0 & 0 & 0 & 0 & 0 & 0 & 0 & 0 & 0 & 0 & 0 & 0 & 0 \\
\hline N-Propanol & 4794.6099 & 0 & 0 & 0 & 0 & 0 & 0 & 0 & 0 & 0 & 0 & 0 & 0 & 0 & 0 \\
\hline Isobutanol & 0 & 0 & 0 & 0 & 0 & 0 & 0 & 0 & 0 & 0 & 0 & 0 & 0 & 0 & 0 \\
\hline N-Butanol & 2053.5737 & 0 & 0 & 0 & 0 & 0 & 0 & 0 & 0 & 0 & 0 & 0 & 0 & 0 & 0 \\
\hline 1-Pentanol & 1024.7623 & 0 & 0 & 0 & 0 & 0 & 0 & 0 & 0 & 0 & 0 & 0 & 0 & 0 & 0 \\
\hline
\end{tabular}




\begin{tabular}{|c|c|c|c|c|c|c|c|c|c|c|c|c|c|c|c|}
\hline Stream No. & 636 & 701 & 702 & 703 & 704 & 706 & 707 & 708 & 709 & 710 & 711 & \multirow{2}{*}{\multicolumn{2}{|c|}{712 VENT }} & 718 & 719 \\
\hline Stream Name & $\mathrm{PrOH}+$ & FROM FLUEIF & $=R O M$ TAR FF & FROM SYNTH & & & STM REF 1 & O SR RECU & & & & & & \multicolumn{2}{|c|}{ TO WWT } \\
\hline Temp F & 230.6059 & 526.5776 & 526.5776 & 526.5776 & 526.5776 & 526.5776 & 526.5776 & 526.5776 & 526.5776 & 526.5776 & 526.5776 & 526.5776 & 233.9624 & 526.5776 & 150 \\
\hline Pres psia & 19 & 860 & 860 & 860 & 860 & 860 & 860 & 860 & 860 & 860 & 860 & 860 & 30 & 860 & 860 \\
\hline Enth MMBtu/h & -15.264 & -316.11 & -596.49 & -701.44 & -3042.5 & -3008.8 & -2191.7 & -792.39 & -24.683 & -27.583 & -33.679 & $-3.96 \mathrm{E}-05$ & 0 & -33.679 & -35.83 \\
\hline Vapor mass fraction & 0 & 0.99 & 0.99 & 0.99043 & 0.99009 & 1 & 1 & 1 & 1 & 0.0095721 & 0 & 1 & 1 & 0 & 0 \\
\hline $\begin{array}{l}\text { Total lb/h } \\
\text { Powrates in lb/h }\end{array}$ & 7884.5376 & 55644.2734 & 105000 & 123479.414 & 535571 & 530265 & 386267 & 139648 & 4350.0005 & 4350.0005 & 5305.981 & 0.007 & 0 & 5305.9736 & 5305.9736 \\
\hline Oxygen & 0 & 0 & 0 & 0 & 0 & 0 & 0 & 0 & 0 & 0 & 0 & 0 & 0 & 0 & 0 \\
\hline Nitrogen & 0 & 0 & 0 & 0 & 0 & 0 & 0 & 0 & 0 & 0 & 0 & 0 & 0 & 0 & 0 \\
\hline Argon & 0 & 0 & 0 & 0 & 0 & 0 & 0 & 0 & 0 & 0 & 0 & 0 & 0 & 0 & 0 \\
\hline Carbon & 0 & 0 & 0 & 0 & 0 & 0 & 0 & 0 & 0 & 0 & 0 & 0 & 0 & 0 & 0 \\
\hline Hydrogen & 0 & 0 & 0 & 0 & 0 & 0 & 0 & 0 & 0 & 0 & 0 & 0 & 0 & 0 & 0 \\
\hline Carbon Monoxide & 0 & 0 & 0 & 0 & 0 & 0 & 0 & 0 & 0 & 0 & 0 & 0 & 0 & 0 & 0 \\
\hline Carbon Dioxide & 0 & 0 & 0 & 0 & 0 & 0 & 0 & 0 & 0 & 0 & 0 & 0 & 0 & 0 & 0 \\
\hline Methane & 0 & 0 & 0 & 0 & 0 & 0 & 0 & 0 & 0 & 0 & 0 & 0 & 0 & 0 & 0 \\
\hline Acetylene & 0 & 0 & 0 & 0 & 0 & 0 & 0 & 0 & 0 & 0 & 0 & 0 & 0 & 0 & 0 \\
\hline Ethylene & 0 & 0 & 0 & 0 & 0 & 0 & 0 & 0 & 0 & 0 & 0 & 0 & 0 & 0 & 0 \\
\hline Ethane & 0 & 0 & 0 & 0 & 0 & 0 & 0 & 0 & 0 & 0 & 0 & 0 & 0 & 0 & 0 \\
\hline Propane & 0 & 0 & 0 & 0 & 0 & 0 & 0 & 0 & 0 & 0 & 0 & 0 & 0 & 0 & 0 \\
\hline Water & 0 & 55644.2734 & 105000 & 123479.414 & 535571 & 530265 & 386267 & 139648 & 4350.0005 & 4350.0005 & 5305.981 & 0.007 & 0 & 5305.9736 & 5305.9736 \\
\hline Sulphur & 0 & 0 & 0 & 0 & 0 & 0 & 0 & 0 & 0 & 0 & 0 & 0 & 0 & 0 & 0 \\
\hline Carbonyl Sulfide & 0 & 0 & 0 & 0 & 0 & 0 & 0 & 0 & 0 & 0 & 0 & 0 & 0 & 0 & 0 \\
\hline Hydrogen Sulfide & 0 & 0 & 0 & 0 & 0 & 0 & 0 & 0 & 0 & 0 & 0 & 0 & 0 & 0 & 0 \\
\hline Ammonia & 0 & 0 & 0 & 0 & 0 & 0 & 0 & 0 & 0 & 0 & 0 & 0 & 0 & 0 & 0 \\
\hline HydrogenChloride & 0 & 0 & 0 & 0 & 0 & 0 & 0 & 0 & 0 & 0 & 0 & 0 & 0 & 0 & 0 \\
\hline Silicon Dioxide & 0 & 0 & 0 & 0 & 0 & 0 & 0 & 0 & 0 & 0 & 0 & 0 & 0 & 0 & 0 \\
\hline Calcium Oxide & 0 & 0 & 0 & 0 & 0 & 0 & 0 & 0 & 0 & 0 & 0 & 0 & 0 & 0 & 0 \\
\hline Benzene & 0 & 0 & 0 & 0 & 0 & 0 & 0 & 0 & 0 & 0 & 0 & 0 & 0 & 0 & 0 \\
\hline Naphthalene & 0 & 0 & 0 & 0 & 0 & 0 & 0 & 0 & 0 & 0 & 0 & 0 & 0 & 0 & 0 \\
\hline Hybrid Poplar Ch & 0 & 0 & 0 & 0 & 0 & 0 & 0 & 0 & 0 & 0 & 0 & 0 & 0 & 0 & 0 \\
\hline Sulfur Dioxide & 0 & 0 & 0 & 0 & 0 & 0 & 0 & 0 & 0 & 0 & 0 & 0 & 0 & 0 & 0 \\
\hline Hydrogen Cyanide & 0 & 0 & 0 & 0 & 0 & 0 & 0 & 0 & 0 & 0 & 0 & 0 & 0 & 0 & 0 \\
\hline Nitric Oxide & 0 & 0 & 0 & 0 & 0 & 0 & 0 & 0 & 0 & 0 & 0 & 0 & 0 & 0 & 0 \\
\hline Methanol & 0.1108 & 0 & 0 & 0 & 0 & 0 & 0 & 0 & 0 & 0 & 0 & 0 & 0 & 0 & 0 \\
\hline Ethanol & 11.4814 & 0 & 0 & 0 & 0 & 0 & 0 & 0 & 0 & 0 & 0 & 0 & 0 & 0 & 0 \\
\hline Isopropanol & 0 & 0 & 0 & 0 & 0 & 0 & 0 & 0 & 0 & 0 & 0 & 0 & 0 & 0 & 0 \\
\hline N-Propanol & 4794.6099 & 0 & 0 & 0 & 0 & 0 & 0 & 0 & 0 & 0 & 0 & 0 & 0 & 0 & 0 \\
\hline Isobutanol & 0 & 0 & 0 & 0 & 0 & 0 & 0 & 0 & 0 & 0 & 0 & 0 & 0 & 0 & 0 \\
\hline N-Butanol & 2053.5737 & 0 & 0 & 0 & 0 & 0 & 0 & 0 & 0 & 0 & 0 & 0 & 0 & 0 & 0 \\
\hline 1-Pentanol & 1024.7623 & 0 & 0 & 0 & 0 & 0 & 0 & 0 & 0 & 0 & 0 & 0 & 0 & 0 & 0 \\
\hline RDF & 0 & 0 & 0 & 0 & 0 & 0 & 0 & 0 & 0 & 0 & 0 & 0 & 0 & 0 & 0 \\
\hline
\end{tabular}




\begin{tabular}{|c|c|c|c|c|c|c|c|c|c|c|c|c|c|c|c|}
\hline Stream No. & 720 & 721 & 725 & 731 & 732 & 736 & 737 & 741 & 742 & 743 & 744 & 745 & 746 & 747 & 751 \\
\hline Stream Name & FROM STM F & FROM SR RE & & & STM REF & & TO S703 & & GASIFIER & & TO MOL SIE & & & & \\
\hline Temp F & 1000 & 1000 & 1000 & 840.6619 & 840.6619 & 840.6619 & 526.5776 & 366.397 & 366.397 & 366.397 & 366.397 & 366.397 & 366.397 & 366.397 & 115.5419 \\
\hline Pres psia & 850 & 850 & 850 & 450 & 450 & 450 & 860 & 35 & 35 & 35 & 35 & 35 & 35 & 35 & 1.5 \\
\hline Enth MMBtu/h & -2071 & -748.74 & -2819.8 & -2858.4 & -734.35 & -2124.1 & -701.44 & -2208.2 & -413.15 & -94.359 & -754.33 & -129.96 & -813.64 & -2.719 & -777.48 \\
\hline Vapor mass fraction & 1 & 1 & 1 & 1 & 1 & 1 & 0.99043 & 1 & 1 & 1 & 1 & 1 & 1 & 1 & 0.93747 \\
\hline $\begin{array}{l}\text { Total Ib/h } \\
\text { Fowrates in lb/h }\end{array}$ & 386270.031 & 139648.406 & 525918.438 & 525918.438 & 135113 & 390805.438 & 123479.414 & 390805.438 & 73120 & 16700 & 133504.219 & 23000 & 144000 & 481.211 & 133504.219 \\
\hline Oxygen & 0 & 0 & 0 & 0 & 0 & 0 & 0 & 0 & 0 & 0 & 0 & 0 & 0 & 0 & 0 \\
\hline Nitrogen & 0 & 0 & 0 & 0 & 0 & 0 & 0 & 0 & 0 & 0 & 0 & 0 & 0 & 0 & 0 \\
\hline Argon & 0 & 0 & 0 & 0 & 0 & 0 & 0 & 0 & 0 & 0 & 0 & 0 & 0 & 0 & 0 \\
\hline Carbon & 0 & 0 & 0 & 0 & 0 & 0 & 0 & 0 & 0 & 0 & 0 & 0 & 0 & 0 & 0 \\
\hline Hydrogen & 0 & 0 & 0 & 0 & 0 & 0 & 0 & 0 & 0 & 0 & 0 & 0 & 0 & 0 & 0 \\
\hline Carbon Monoxide & 0 & 0 & 0 & 0 & 0 & 0 & 0 & 0 & 0 & 0 & 0 & 0 & 0 & 0 & 0 \\
\hline Carbon Dioxide & 0 & 0 & 0 & 0 & 0 & 0 & 0 & 0 & 0 & 0 & 0 & 0 & 0 & 0 & 0 \\
\hline Methane & 0 & 0 & 0 & 0 & 0 & 0 & 0 & 0 & 0 & 0 & 0 & 0 & 0 & 0 & 0 \\
\hline Acetylene & 0 & 0 & 0 & 0 & 0 & 0 & 0 & 0 & 0 & 0 & 0 & 0 & 0 & 0 & 0 \\
\hline Ethylene & 0 & 0 & 0 & 0 & 0 & 0 & 0 & 0 & 0 & 0 & 0 & 0 & 0 & 0 & 0 \\
\hline Ethane & 0 & 0 & 0 & 0 & 0 & 0 & 0 & 0 & 0 & 0 & 0 & 0 & 0 & 0 & 0 \\
\hline Propane & 0 & 0 & 0 & 0 & 0 & 0 & 0 & 0 & 0 & 0 & 0 & 0 & 0 & 0 & 0 \\
\hline Water & 386270.031 & 139648.406 & 525918.438 & 525918.438 & 135113 & 390805.438 & 123479.414 & 390805.438 & 73120 & 16700 & 133504.219 & 23000 & 144000 & 481.211 & 133504.219 \\
\hline Sulphur & 0 & 0 & 0 & 0 & 0 & 0 & 0 & 0 & 0 & 0 & 0 & 0 & 0 & 0 & 0 \\
\hline Carbonyl Sulfide & 0 & 0 & 0 & 0 & 0 & 0 & 0 & 0 & 0 & 0 & 0 & 0 & 0 & 0 & 0 \\
\hline Hydrogen Sulfide & 0 & 0 & 0 & 0 & 0 & 0 & 0 & 0 & 0 & 0 & 0 & 0 & 0 & 0 & 0 \\
\hline Ammonia & 0 & 0 & 0 & 0 & 0 & 0 & 0 & 0 & 0 & 0 & 0 & 0 & 0 & 0 & 0 \\
\hline HydrogenChloride & 0 & 0 & 0 & 0 & 0 & 0 & 0 & 0 & 0 & 0 & 0 & 0 & 0 & 0 & 0 \\
\hline Silicon Dioxide & 0 & 0 & 0 & 0 & 0 & 0 & 0 & 0 & 0 & 0 & 0 & 0 & 0 & 0 & 0 \\
\hline Calcium Oxide & 0 & 0 & 0 & 0 & 0 & 0 & 0 & 0 & 0 & 0 & 0 & 0 & 0 & 0 & 0 \\
\hline Benzene & 0 & 0 & 0 & 0 & 0 & 0 & 0 & 0 & 0 & 0 & 0 & 0 & 0 & 0 & 0 \\
\hline Naphthal ene & 0 & 0 & 0 & 0 & 0 & 0 & 0 & 0 & 0 & 0 & 0 & 0 & 0 & 0 & 0 \\
\hline Hybrid Poplar Ch & 0 & 0 & 0 & 0 & 0 & 0 & 0 & 0 & 0 & 0 & 0 & 0 & 0 & 0 & 0 \\
\hline Sulfur Dioxide & 0 & 0 & 0 & 0 & 0 & 0 & 0 & 0 & 0 & 0 & 0 & 0 & 0 & 0 & 0 \\
\hline Hydrogen Cyanide & 0 & 0 & 0 & 0 & 0 & 0 & 0 & 0 & 0 & 0 & 0 & 0 & 0 & 0 & 0 \\
\hline Nitric Oxide & 0 & 0 & 0 & 0 & 0 & 0 & 0 & 0 & 0 & 0 & 0 & 0 & 0 & 0 & 0 \\
\hline Methanol & 0 & 0 & 0 & 0 & 0 & 0 & 0 & 0 & 0 & 0 & 0 & 0 & 0 & 0 & 0 \\
\hline Ethanol & 0 & 0 & 0 & 0 & 0 & 0 & 0 & 0 & 0 & 0 & 0 & 0 & 0 & 0 & 0 \\
\hline Isopropanol & 0 & 0 & 0 & 0 & 0 & 0 & 0 & 0 & 0 & 0 & 0 & 0 & 0 & 0 & 0 \\
\hline N-Propanol & 0 & 0 & 0 & 0 & 0 & 0 & 0 & 0 & 0 & 0 & 0 & 0 & 0 & 0 & 0 \\
\hline Isobutanol & 0 & 0 & 0 & 0 & 0 & 0 & 0 & 0 & 0 & 0 & 0 & 0 & 0 & 0 & 0 \\
\hline N-Butanol & 0 & 0 & 0 & 0 & 0 & 0 & 0 & 0 & 0 & 0 & 0 & 0 & 0 & 0 & 0 \\
\hline 1-Pentanol & 0 & 0 & 0 & 0 & 0 & 0 & 0 & 0 & 0 & 0 & 0 & 0 & 0 & 0 & 0 \\
\hline RDF & 0 & 0 & 0 & 0 & 0 & 0 & 0 & 0 & 0 & 0 & 0 & 0 & 0 & 0 & \\
\hline
\end{tabular}




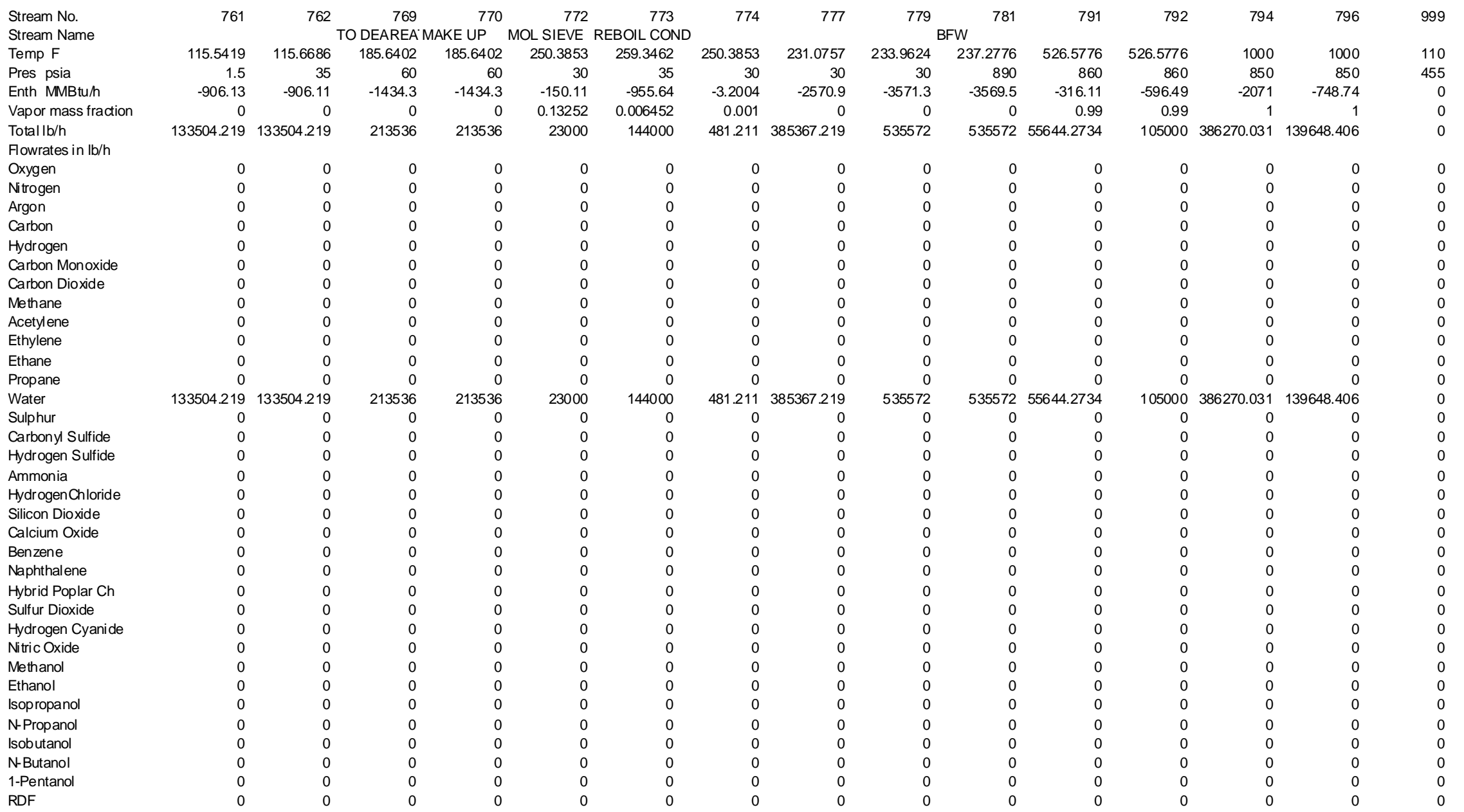




\begin{tabular}{|c|c|c|c|c|c|c|c|c|c|c|c|c|c|c|c|}
\hline Stream No. & 1602 & 1701 & 1702 & 1703 & 1741 & 1742 & 1743 & 1744 & 1745 & \multirow{2}{*}{\multicolumn{2}{|c|}{ TO WWT }} & \multirow{2}{*}{\multicolumn{2}{|c|}{$\begin{array}{c}1 / 48 \\
\text { to WWT }\end{array}$}} & 1750 & $\begin{array}{r}1751 \\
\text { to SCRUBBE }\end{array}$ \\
\hline Stream Name & FUEL GAS & TO WWT & & & & & & & & & & & & TO DEAREA & to SCRUBBE \\
\hline Temp F & 75.4944 & 118.6996 & 118.7001 & 118.7001 & 253.7146 & 272.2724 & 0 & 195.4259 & 195.4258 & 209.108 & 204.9788 & 231.2095 & 211.4502 & 171.9244 & 110 \\
\hline Pres psia & 16 & 15 & 15 & 15 & 28 & 54 & 0 & 109.5 & 109.5 & 220 & 109.5 & 465 & 109.5 & 109.5 & 427.5 \\
\hline Enth MMBtu/h & -152.54 & -66730 & -667.23 & -66055 & 0 & 0 & 0 & -12.489 & -12.489 & -28.801 & -41.29 & -13.438 & -54.728 & -90.088 & -847.07 \\
\hline Vapor mass fraction & 1 & 0 & 0 & 0 & 0 & 0 & 0 & 0 & 0 & 0 & 0 & 0 & 0 & 0 & 0 \\
\hline $\begin{array}{l}\text { Total Ib/h } \\
\text { Fowrates in lb/h }\end{array}$ & 69501.1563 & 9860562 & 98595 & 9760903 & 0 & 0 & 0 & 1862.0194 & 1862.0194 & 4302.9282 & 6164.9473 & 2014.3109 & 8179.2583 & 13486.0625 & 124701.398 \\
\hline Oxygen & 0 & 0 & 0 & 0 & 0 & 0 & 0 & 0 & 0 & 0 & 0 & 0 & 0 & 0 & 0 \\
\hline Nitrogen & 383.4176 & 0.2378 & 0.0024 & 0.2354 & 0 & 0 & 0 & 0 & 0 & 0 & 0 & 0 & 0 & 0.0018 & 0 \\
\hline Argon & 0 & 0 & 0 & 0 & 0 & 0 & 0 & 0 & 0 & 0 & 0 & 0 & 0 & 0 & 0 \\
\hline Carbon & 0 & 0 & 0 & 0 & 0 & 0 & 0 & 0 & 0 & 0 & 0 & 0 & 0 & 0 & 0 \\
\hline Hydrogen & 3405.0361 & 4.7488 & 0.0475 & 4.7008 & 0 & 0 & 0 & 0 & 0 & 0 & 0 & 0 & 0 & 0.0108 & 0 \\
\hline Carbon Monoxide & 41200.3203 & 60.2127 & 0.6021 & 59.6037 & 0 & 0 & 0 & 0 & 0 & 0 & 0 & 0 & 0 & 0.3159 & 0 \\
\hline Carbon Dioxide & 17461.6094 & 30002.0762 & 299.9464 & 29694.6875 & 0 & 0 & 0 & 0 & 0 & 0 & 0 & 0 & 0 & 1.7083 & 0 \\
\hline Methane & 4690.6763 & 10.2895 & 0.1029 & 10.1854 & 0 & 0 & 0 & 0 & 0 & 0 & 0 & 0 & 0 & 0.1385 & 0 \\
\hline Acetylene & 0.0005 & 0.2898 & 0.0029 & 0.2868 & 0 & 0 & 0 & 0 & 0 & 0 & 0 & 0 & 0 & 0.0265 & 0 \\
\hline Ethylene & 0.0904 & 37.7117 & 0.3771 & 37.3303 & 0 & 0 & 0 & 0 & 0 & 0 & 0 & 0 & 0 & 0.703 & 0 \\
\hline Ethane & 203.5968 & 0.1572 & 0.0016 & 0.1556 & 0 & 0 & 0 & 0 & 0 & 0 & 0 & 0 & 0 & 0.0125 & 0 \\
\hline Propane & 0 & 0 & 0 & 0 & 0 & 0 & 0 & 0 & 0 & 0 & 0 & 0 & 0 & 0 & 0 \\
\hline Water & 66.4548 & 9815512 & 98144.5938 & 9716314 & 0 & 0 & 0 & 1862.0194 & 1862.0194 & 4302.9282 & 6164.9473 & 2014.3109 & 8179.2583 & 13388.4365 & 124701.398 \\
\hline Sulphur & 0 & 0 & 0 & 0 & 0 & 0 & 0 & 0 & 0 & 0 & 0 & 0 & 0 & 0 & 0 \\
\hline Carbonyl Sulfide & 0 & 0 & 0 & 0 & 0 & 0 & 0 & 0 & 0 & 0 & 0 & 0 & 0 & 0 & 0 \\
\hline Hydrogen Sulfide & 0 & 965.9637 & 9.6576 & 956.1025 & 0 & 0 & 0 & 0 & 0 & 0 & 0 & 0 & 0 & 0.1328 & 0 \\
\hline Ammonia & 10.9824 & 13968.4805 & 139.6469 & 13825.0391 & 0 & 0 & 0 & 0 & 0 & 0 & 0 & 0 & 0 & 0.0335 & 0 \\
\hline HydrogenChloride & 0 & 0 & 0 & 0 & 0 & 0 & 0 & 0 & 0 & 0 & 0 & 0 & 0 & 0 & 0 \\
\hline Silicon Dioxide & 0 & 0 & 0 & 0 & 0 & 0 & 0 & 0 & 0 & 0 & 0 & 0 & 0 & 0 & 0 \\
\hline Calcium Oxide & 0 & 0 & 0 & 0 & 0 & 0 & 0 & 0 & 0 & 0 & 0 & 0 & 0 & 0 & 0 \\
\hline Benzene & 0 & 0.4656 & 0.0047 & 0.4609 & 0 & 0 & 0 & 0 & 0 & 0 & 0 & 0 & 0 & 5.2171 & 0 \\
\hline Naphthal ene & 0 & 0.1412 & 0.0014 & 0.1397 & 0 & 0 & 0 & 0 & 0 & 0 & 0 & 0 & 0 & 89.3262 & 0 \\
\hline Hybrid Poplar Ch & 0 & 0 & 0 & 0 & 0 & 0 & 0 & 0 & 0 & 0 & 0 & 0 & 0 & 0 & 0 \\
\hline Sulfur Dioxide & 0 & 0 & 0 & 0 & 0 & 0 & 0 & 0 & 0 & 0 & 0 & 0 & 0 & 0 & 0 \\
\hline Hydrogen Cyanide & 0.165 & 0 & 0 & 0 & 0 & 0 & 0 & 0 & 0 & 0 & 0 & 0 & 0 & 0 & 0 \\
\hline Nitric Oxide & 0 & 0 & 0 & 0 & 0 & 0 & 0 & 0 & 0 & 0 & 0 & 0 & 0 & 0 & 0 \\
\hline Methanol & 1686.7837 & 0 & 0 & 0 & 0 & 0 & 0 & 0 & 0 & 0 & 0 & 0 & 0 & 0 & 0 \\
\hline Ethanol & 342.8955 & 0 & 0 & 0 & 0 & 0 & 0 & 0 & 0 & 0 & 0 & 0 & 0 & 0 & 0 \\
\hline Isopropanol & 0 & 0 & 0 & 0 & 0 & 0 & 0 & 0 & 0 & 0 & 0 & 0 & 0 & 0 & 0 \\
\hline N-Propanol & 37.2493 & 0 & 0 & 0 & 0 & 0 & 0 & 0 & 0 & 0 & 0 & 0 & 0 & 0 & 0 \\
\hline Isobutanol & 0 & 0 & 0 & 0 & 0 & 0 & 0 & 0 & 0 & 0 & 0 & 0 & 0 & 0 & 0 \\
\hline N-Butanol & 8.0933 & 0 & 0 & 0 & 0 & 0 & 0 & 0 & 0 & 0 & 0 & 0 & 0 & 0 & 0 \\
\hline 1-Pentanol & 3.7836 & 0 & 0 & 0 & 0 & 0 & 0 & 0 & 0 & 0 & 0 & 0 & 0 & 0 & 0 \\
\hline RDF & 0 & 0 & 0 & 0 & 0 & 0 & 0 & 0 & 0 & 0 & 0 & 0 & 0 & 0 & 0 \\
\hline
\end{tabular}




\begin{tabular}{|c|c|c|c|c|c|c|c|c|c|c|c|c|c|c|c|}
\hline $\begin{array}{l}\text { Stream No. } \\
\text { Stream Name }\end{array}$ & CWs ${ }^{1830}$ & \multicolumn{2}{|c|}{ CWS } & 1835 & CWS & \multicolumn{4}{|c|}{ CWS } & 1851 & 1861 & 1862 & 1871 & \multicolumn{2}{|c|}{ STEAM } \\
\hline Temp F & 90 & 110 & 90 & 110 & 90 & 110 & 90 & 110 & 90 & 110 & 90 & 110 & 90 & 110 & 259.3482 \\
\hline Pres psia & 60 & 60 & 60 & 60 & 65 & 65 & 65 & 65 & 65 & 60 & 60 & 60 & 65 & 60 & 35 \\
\hline Enth MMBtu/h & -25113 & -25039 & -2097.5 & -2091.3 & -690.94 & -688.92 & -4435.2 & -4422.2 & -1849.9 & -1844.5 & -2604.6 & -2594 & -43820 & -43691 & -417.08 \\
\hline Vapor mass fraction & 0 & 0 & 0 & 0 & 0 & 0 & 0 & 0 & 0 & 0 & 0 & 0 & 0 & 0 & 1 \\
\hline $\begin{array}{l}\text { Total Ib/h } \\
\text { Fowrates in lb/h }\end{array}$ & 3686166 & 3686166 & 307872 & 307872 & 101418.43 & 101418.43 & 651012.188 & 651012.188 & 271534 & 271534 & 382314 & 382314 & 6431974 & 6431974 & 73119.7656 \\
\hline Oxygen & 0 & 0 & 0 & 0 & 0 & 0 & 0 & 0 & 0 & 0 & 0 & 0 & 0 & 0 & 0 \\
\hline Nitrogen & 0 & 0 & 0 & 0 & 0 & 0 & 0 & 0 & 0 & 0 & 0 & 0 & 0 & 0 & 0 \\
\hline Argon & 0 & 0 & 0 & 0 & 0 & 0 & 0 & 0 & 0 & 0 & 0 & 0 & 0 & 0 & 0 \\
\hline Carbon & 0 & 0 & 0 & 0 & 0 & 0 & 0 & 0 & 0 & 0 & 0 & 0 & 0 & 0 & 0 \\
\hline Hydrogen & 0 & 0 & 0 & 0 & 0 & 0 & 0 & 0 & 0 & 0 & 0 & 0 & 0 & 0 & 0 \\
\hline Carbon Monoxide & 0 & 0 & 0 & 0 & 0 & 0 & 0 & 0 & 0 & 0 & 0 & 0 & 0 & 0 & 0 \\
\hline Carbon Dioxide & 0 & 0 & 0 & 0 & 0 & 0 & 0 & 0 & 0 & 0 & 0 & 0 & 0 & 0 & 0 \\
\hline Methane & 0 & 0 & 0 & 0 & 0 & 0 & 0 & 0 & 0 & 0 & 0 & 0 & 0 & 0 & 0 \\
\hline Acetylene & 0 & 0 & 0 & 0 & 0 & 0 & 0 & 0 & 0 & 0 & 0 & 0 & 0 & 0 & 0 \\
\hline Ethylene & 0 & 0 & 0 & 0 & 0 & 0 & 0 & 0 & 0 & 0 & 0 & 0 & 0 & 0 & 0 \\
\hline Ethane & 0 & 0 & 0 & 0 & 0 & 0 & 0 & 0 & 0 & 0 & 0 & 0 & 0 & 0 & 0 \\
\hline Propane & 0 & 0 & 0 & 0 & 0 & 0 & 0 & 0 & 0 & 0 & 0 & 0 & 0 & 0 & 0 \\
\hline Water & 3686166 & 3686166 & 307872 & 307872 & 101418.43 & 101418.43 & 651012.188 & 651012.188 & 271534 & 271534 & 382314 & 382314 & 6431974 & 6431974 & 73119.7656 \\
\hline Sulphur & 0 & 0 & 0 & 0 & 0 & 0 & 0 & 0 & 0 & 0 & 0 & 0 & 0 & 0 & 0 \\
\hline Carbonyl Sulfide & 0 & 0 & 0 & 0 & 0 & 0 & 0 & 0 & 0 & 0 & 0 & 0 & 0 & 0 & 0 \\
\hline Hydrogen Sulfide & 0 & 0 & 0 & 0 & 0 & 0 & 0 & 0 & 0 & 0 & 0 & 0 & 0 & 0 & 0 \\
\hline Ammonia & 0 & 0 & 0 & 0 & 0 & 0 & 0 & 0 & 0 & 0 & 0 & 0 & 0 & 0 & 0 \\
\hline HydrogenChloride & 0 & 0 & 0 & 0 & 0 & 0 & 0 & 0 & 0 & 0 & 0 & 0 & 0 & 0 & 0 \\
\hline Silicon Dioxide & 0 & 0 & 0 & 0 & 0 & 0 & 0 & 0 & 0 & 0 & 0 & 0 & 0 & 0 & 0 \\
\hline Calcium Oxide & 0 & 0 & 0 & 0 & 0 & 0 & 0 & 0 & 0 & 0 & 0 & 0 & 0 & 0 & 0 \\
\hline Benzene & 0 & 0 & 0 & 0 & 0 & 0 & 0 & 0 & 0 & 0 & 0 & 0 & 0 & 0 & 0 \\
\hline Naphthalene & 0 & 0 & 0 & 0 & 0 & 0 & 0 & 0 & 0 & 0 & 0 & 0 & 0 & 0 & 0 \\
\hline Hybrid Poplar Ch & 0 & 0 & 0 & 0 & 0 & 0 & 0 & 0 & 0 & 0 & 0 & 0 & 0 & 0 & 0 \\
\hline Sulfur Dioxide & 0 & 0 & 0 & 0 & 0 & 0 & 0 & 0 & 0 & 0 & 0 & 0 & 0 & 0 & 0 \\
\hline Hydrogen Cyanide & 0 & 0 & 0 & 0 & 0 & 0 & 0 & 0 & 0 & 0 & 0 & 0 & 0 & 0 & 0 \\
\hline Nitric Oxide & 0 & 0 & 0 & 0 & 0 & 0 & 0 & 0 & 0 & 0 & 0 & 0 & 0 & 0 & 0 \\
\hline Methanol & 0 & 0 & 0 & 0 & 0 & 0 & 0 & 0 & 0 & 0 & 0 & 0 & 0 & 0 & 0 \\
\hline Ethanol & 0 & 0 & 0 & 0 & 0 & 0 & 0 & 0 & 0 & 0 & 0 & 0 & 0 & 0 & 0 \\
\hline Isopropanol & 0 & 0 & 0 & 0 & 0 & 0 & 0 & 0 & 0 & 0 & 0 & 0 & 0 & 0 & 0 \\
\hline N-Propanol & 0 & 0 & 0 & 0 & 0 & 0 & 0 & 0 & 0 & 0 & 0 & 0 & 0 & 0 & 0 \\
\hline Isobutanol & 0 & 0 & 0 & 0 & 0 & 0 & 0 & 0 & 0 & 0 & 0 & 0 & 0 & 0 & 0 \\
\hline N-Butanol & 0 & 0 & 0 & 0 & 0 & 0 & 0 & 0 & 0 & 0 & 0 & 0 & 0 & 0 & 0 \\
\hline 1-Pentanol & 0 & 0 & 0 & 0 & 0 & 0 & 0 & 0 & 0 & 0 & 0 & 0 & 0 & 0 & 0 \\
\hline $\mathrm{RDF}$ & 0 & 0 & 0 & 0 & 0 & 0 & 0 & 0 & 0 & 0 & 0 & 0 & 0 & 0 & 0 \\
\hline
\end{tabular}




\begin{tabular}{|c|c|c|c|c|c|c|c|c|c|c|c|c|c|c|c|}
\hline Stream No. & 1931 & 1932 & 1935 & 1936 & 1938 & 1940 & 1941 & 1942 & 1943 & 1944 & 1945 & 1946 & 1950 & 1951 & 1952 \\
\hline Stream Name & BFW & to STM DRUIBFW & & MP STEAM $\mathrm{t}$ & to STM DRUIS & TEAM & SAT'D STM & TO TURBINE & & & TEAM & to TURBINE & FW & O STM DRL E & BFW \\
\hline Temp F & 237 & 526.5776 & 237 & 400 & 526.5776 & 715.0002 & 525.2153 & 1000 & 525.2153 & 1000 & 366.401 & 259.3462 & 237 & 526.5776 & 237 \\
\hline Pres psia & 860 & 860 & 860 & 860 & 860 & 450 & 850 & 850 & 850 & 850 & 35 & 35 & 860 & 860 & 860 \\
\hline Enth MMBtu/h & -370.88 & -316.11 & -699.84 & -681.92 & -596.49 & -743.52 & -792.35 & -748.74 & -2191.6 & -2071 & -2.7189 & -3.1959 & -1675.9 & -1428.4 & -823.01 \\
\hline Vapor mass fraction & 0 & 0.99 & 0 & 0 & 0.99 & 1 & 1 & 1 & 1 & 1 & 1 & 0.001 & 0 & 0.99 & 0 \\
\hline $\begin{array}{l}\text { Total Ib/h } \\
\text { Fowrates in lb/h }\end{array}$ & 55644.2734 & 55644.2734 & 105000 & 105000 & 105000 & 135112.5 & 139648.406 & 139648.406 & 386270.031 & 386270.031 & 481.1948 & 481.1948 & 251447 & 251447 & 123479.414 \\
\hline Oxygen & 0 & 0 & 0 & 0 & 0 & 0 & 0 & 0 & 0 & 0 & 0 & 0 & 0 & 0 & 0 \\
\hline Nitrogen & 0 & 0 & 0 & 0 & 0 & 0 & 0 & 0 & 0 & 0 & 0 & 0 & 0 & 0 & 0 \\
\hline Argon & 0 & 0 & 0 & 0 & 0 & 0 & 0 & 0 & 0 & 0 & 0 & 0 & 0 & 0 & 0 \\
\hline Carbon & 0 & 0 & 0 & 0 & 0 & 0 & 0 & 0 & 0 & 0 & 0 & 0 & 0 & 0 & 0 \\
\hline Hydrogen & 0 & 0 & 0 & 0 & 0 & 0 & 0 & 0 & 0 & 0 & 0 & 0 & 0 & 0 & 0 \\
\hline Carbon Monoxide & 0 & 0 & 0 & 0 & 0 & 0 & 0 & 0 & 0 & 0 & 0 & 0 & 0 & 0 & 0 \\
\hline Carbon Dioxide & 0 & 0 & 0 & 0 & 0 & 0 & 0 & 0 & 0 & 0 & 0 & 0 & 0 & 0 & 0 \\
\hline Methane & 0 & 0 & 0 & 0 & 0 & 0 & 0 & 0 & 0 & 0 & 0 & 0 & 0 & 0 & 0 \\
\hline Acetylene & 0 & 0 & 0 & 0 & 0 & 0 & 0 & 0 & 0 & 0 & 0 & 0 & 0 & 0 & 0 \\
\hline Ethylene & 0 & 0 & 0 & 0 & 0 & 0 & 0 & 0 & 0 & 0 & 0 & 0 & 0 & 0 & 0 \\
\hline Ethane & 0 & 0 & 0 & 0 & 0 & 0 & 0 & 0 & 0 & 0 & 0 & 0 & 0 & 0 & 0 \\
\hline Propane & 0 & 0 & 0 & 0 & 0 & 0 & 0 & 0 & 0 & 0 & 0 & 0 & 0 & 0 & 0 \\
\hline Water & 55644.2734 & 55644.2734 & 105000 & 105000 & 105000 & 135112.5 & 139648.406 & 139648.406 & 386270.031 & 386270.031 & 481.1948 & 481.1948 & 251447 & 251447 & 123479.414 \\
\hline Sulphur & 0 & 0 & 0 & 0 & 0 & 0 & 0 & 0 & 0 & 0 & 0 & 0 & 0 & 0 & 0 \\
\hline Carbonyl Sulfide & 0 & 0 & 0 & 0 & 0 & 0 & 0 & 0 & 0 & 0 & 0 & 0 & 0 & 0 & 0 \\
\hline Hydrogen Sulfide & 0 & 0 & 0 & 0 & 0 & 0 & 0 & 0 & 0 & 0 & 0 & 0 & 0 & 0 & 0 \\
\hline Ammonia & 0 & 0 & 0 & 0 & 0 & 0 & 0 & 0 & 0 & 0 & 0 & 0 & 0 & 0 & 0 \\
\hline HydrogenChloride & 0 & 0 & 0 & 0 & 0 & 0 & 0 & 0 & 0 & 0 & 0 & 0 & 0 & 0 & 0 \\
\hline Silicon Dioxide & 0 & 0 & 0 & 0 & 0 & 0 & 0 & 0 & 0 & 0 & 0 & 0 & 0 & 0 & 0 \\
\hline Calcium Oxide & 0 & 0 & 0 & 0 & 0 & 0 & 0 & 0 & 0 & 0 & 0 & 0 & 0 & 0 & 0 \\
\hline Benzene & 0 & 0 & 0 & 0 & 0 & 0 & 0 & 0 & 0 & 0 & 0 & 0 & 0 & 0 & 0 \\
\hline Naphthalene & 0 & 0 & 0 & 0 & 0 & 0 & 0 & 0 & 0 & 0 & 0 & 0 & 0 & 0 & 0 \\
\hline Hybrid Poplar Ch & 0 & 0 & 0 & 0 & 0 & 0 & 0 & 0 & 0 & 0 & 0 & 0 & 0 & 0 & 0 \\
\hline Sulfur Dioxide & 0 & 0 & 0 & 0 & 0 & 0 & 0 & 0 & 0 & 0 & 0 & 0 & 0 & 0 & 0 \\
\hline Hydrogen Cyanide & 0 & 0 & 0 & 0 & 0 & 0 & 0 & 0 & 0 & 0 & 0 & 0 & 0 & 0 & 0 \\
\hline Nitric Oxide & 0 & 0 & 0 & 0 & 0 & 0 & 0 & 0 & 0 & 0 & 0 & 0 & 0 & 0 & 0 \\
\hline Methanol & 0 & 0 & 0 & 0 & 0 & 0 & 0 & 0 & 0 & 0 & 0 & 0 & 0 & 0 & 0 \\
\hline Ethanol & 0 & 0 & 0 & 0 & 0 & 0 & 0 & 0 & 0 & 0 & 0 & 0 & 0 & 0 & 0 \\
\hline Isopropanol & 0 & 0 & 0 & 0 & 0 & 0 & 0 & 0 & 0 & 0 & 0 & 0 & 0 & 0 & 0 \\
\hline N-Propanol & 0 & 0 & 0 & 0 & 0 & 0 & 0 & 0 & 0 & 0 & 0 & 0 & 0 & 0 & 0 \\
\hline Isobutanol & 0 & 0 & 0 & 0 & 0 & 0 & 0 & 0 & 0 & 0 & 0 & 0 & 0 & 0 & 0 \\
\hline N-Butanol & 0 & 0 & 0 & 0 & 0 & 0 & 0 & 0 & 0 & 0 & 0 & 0 & 0 & 0 & 0 \\
\hline 1-Pentanol & 0 & 0 & 0 & 0 & 0 & 0 & 0 & 0 & 0 & 0 & 0 & 0 & 0 & 0 & 0 \\
\hline RDF & 0 & 0 & 0 & 0 & 0 & 0 & 0 & 0 & 0 & 0 & 0 & 0 & 0 & 0 & 0 \\
\hline
\end{tabular}




\begin{tabular}{|c|c|c|c|c|c|c|c|c|c|c|c|c|c|c|c|}
\hline Stream No. & 1931 & 1932 & 1935 & 1936 & 1938 & 1940 & 1941 & 1942 & 1943 & 1944 & 1945 & $\quad 1946$ & 1950 & 1951 & 1952 \\
\hline Stream Name & BFW & to STM DRUIBFW & & STEAM & to STM DRUIS & TEAM & SAT'D STM & TO TURBINE & & & STEAM & to TURBINE & BFW & TO STM DRL & BFW \\
\hline Temp F & 237 & 526.5776 & 237 & 400 & 526.5776 & 715.0002 & 525.2153 & 1000 & 525.2153 & 1000 & 366.401 & 259.3462 & 237 & 526.5776 & 237 \\
\hline Pres psia & 860 & 860 & 860 & 860 & 860 & 450 & 850 & 850 & 850 & 850 & 35 & 35 & 860 & 860 & 860 \\
\hline Enth MMBtu/h & -370.88 & -316.11 & -699.84 & -681.92 & -596.49 & -743.52 & -792.35 & -748.74 & -2191.6 & -2071 & -2.7189 & -3.1959 & -1675.9 & -1428.4 & -823.01 \\
\hline Vapor mass fraction & 0 & 0.99 & 0 & 0 & 0.99 & 1 & 1 & 1 & 1 & 1 & 1 & 0.001 & 0 & 0.99 & 0 \\
\hline Total lb/h & 55644.2734 & 55644.2734 & 105000 & 105000 & 105000 & 135112.5 & 139648.406 & 139648.406 & 386270.031 & 386270.031 & 481.1948 & 481.1948 & 251447 & 251447 & 123479.414 \\
\hline Howrates in lb/h & & & & & & & & & & & & & & & \\
\hline Oxygen & 0 & 0 & 0 & 0 & 0 & 0 & 0 & 0 & 0 & 0 & 0 & 0 & 0 & 0 & 0 \\
\hline Nitrogen & 0 & 0 & 0 & 0 & 0 & 0 & 0 & 0 & 0 & 0 & 0 & 0 & 0 & 0 & 0 \\
\hline Argon & 0 & 0 & 0 & 0 & 0 & 0 & 0 & 0 & 0 & 0 & 0 & 0 & 0 & 0 & 0 \\
\hline Carbon & 0 & 0 & 0 & 0 & 0 & 0 & 0 & 0 & 0 & 0 & 0 & 0 & 0 & 0 & 0 \\
\hline Hydrogen & 0 & 0 & 0 & 0 & 0 & 0 & 0 & 0 & 0 & 0 & 0 & 0 & 0 & 0 & 0 \\
\hline Carbon Monoxide & 0 & 0 & 0 & 0 & 0 & 0 & 0 & 0 & 0 & 0 & 0 & 0 & 0 & 0 & 0 \\
\hline Carbon Dioxide & 0 & 0 & 0 & 0 & 0 & 0 & 0 & 0 & 0 & 0 & 0 & 0 & 0 & 0 & 0 \\
\hline Methane & 0 & 0 & 0 & 0 & 0 & 0 & 0 & 0 & 0 & 0 & 0 & 0 & 0 & 0 & 0 \\
\hline Acetylene & 0 & 0 & 0 & 0 & 0 & 0 & 0 & 0 & 0 & 0 & 0 & 0 & 0 & 0 & 0 \\
\hline Ethylene & 0 & 0 & 0 & 0 & 0 & 0 & 0 & 0 & 0 & 0 & 0 & 0 & 0 & 0 & 0 \\
\hline Ethane & 0 & 0 & 0 & 0 & 0 & 0 & 0 & 0 & 0 & 0 & 0 & 0 & 0 & 0 & 0 \\
\hline Propane & 0 & 0 & 0 & 0 & 0 & 0 & 0 & 0 & 0 & 0 & 0 & 0 & 0 & 0 & 0 \\
\hline Water & 55644.2734 & 55644.2734 & 105000 & 105000 & 105000 & 135112.5 & 139648.406 & 139648.406 & 386270.031 & 386270.031 & 481.1948 & 481.1948 & 251447 & 251447 & 123479.414 \\
\hline Sulphur & 0 & 0 & 0 & 0 & 0 & 0 & 0 & 0 & 0 & 0 & 0 & 0 & 0 & 0 & 0 \\
\hline Carbonyl Sulfide & 0 & 0 & 0 & 0 & 0 & 0 & 0 & 0 & 0 & 0 & 0 & 0 & 0 & 0 & 0 \\
\hline Hydrogen Sulfide & 0 & 0 & 0 & 0 & 0 & 0 & 0 & 0 & 0 & 0 & 0 & 0 & 0 & 0 & 0 \\
\hline Ammonia & 0 & 0 & 0 & 0 & 0 & 0 & 0 & 0 & 0 & 0 & 0 & 0 & 0 & 0 & 0 \\
\hline HydrogenChloride & 0 & 0 & 0 & 0 & 0 & 0 & 0 & 0 & 0 & 0 & 0 & 0 & 0 & 0 & 0 \\
\hline Silicon Dioxide & 0 & 0 & 0 & 0 & 0 & 0 & 0 & 0 & 0 & 0 & 0 & 0 & 0 & 0 & 0 \\
\hline Calcium Oxide & 0 & 0 & 0 & 0 & 0 & 0 & 0 & 0 & 0 & 0 & 0 & 0 & 0 & 0 & 0 \\
\hline Benzene & 0 & 0 & 0 & 0 & 0 & 0 & 0 & 0 & 0 & 0 & 0 & 0 & 0 & 0 & 0 \\
\hline Naphthalene & 0 & 0 & 0 & 0 & 0 & 0 & 0 & 0 & 0 & 0 & 0 & 0 & 0 & 0 & 0 \\
\hline Hybrid Poplar Ch & 0 & 0 & 0 & 0 & 0 & 0 & 0 & 0 & 0 & 0 & 0 & 0 & 0 & 0 & 0 \\
\hline Sulfur Dioxide & 0 & 0 & 0 & 0 & 0 & 0 & 0 & 0 & 0 & 0 & 0 & 0 & 0 & 0 & 0 \\
\hline Hydrogen Cyanide & 0 & 0 & 0 & 0 & 0 & 0 & 0 & 0 & 0 & 0 & 0 & 0 & 0 & 0 & 0 \\
\hline Nitric Oxide & 0 & 0 & 0 & 0 & 0 & 0 & 0 & 0 & 0 & 0 & 0 & 0 & 0 & 0 & 0 \\
\hline Methanol & 0 & 0 & 0 & 0 & 0 & 0 & 0 & 0 & 0 & 0 & 0 & 0 & 0 & 0 & 0 \\
\hline Ethanol & 0 & 0 & 0 & 0 & 0 & 0 & 0 & 0 & 0 & 0 & 0 & 0 & 0 & 0 & 0 \\
\hline Isopropanol & 0 & 0 & 0 & 0 & 0 & 0 & 0 & 0 & 0 & 0 & 0 & 0 & 0 & 0 & 0 \\
\hline N-Propanol & 0 & 0 & 0 & 0 & 0 & 0 & 0 & 0 & 0 & 0 & 0 & 0 & 0 & 0 & 0 \\
\hline Isobutanol & 0 & 0 & 0 & 0 & 0 & 0 & 0 & 0 & 0 & 0 & 0 & 0 & 0 & 0 & 0 \\
\hline N-Butanol & 0 & 0 & 0 & 0 & 0 & 0 & 0 & 0 & 0 & 0 & 0 & 0 & 0 & 0 & 0 \\
\hline 1-Pentanol & 0 & 0 & 0 & 0 & 0 & 0 & 0 & 0 & 0 & 0 & 0 & 0 & 0 & 0 & 0 \\
\hline RDF & 0 & 0 & 0 & 0 & 0 & 0 & 0 & 0 & 0 & 0 & 0 & 0 & 0 & 0 & 0 \\
\hline
\end{tabular}




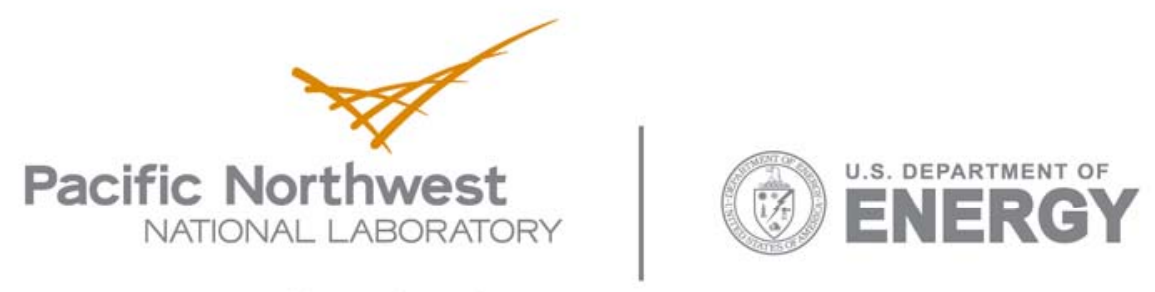

902 Battelle Boulevard

P.O. Box 999

Richland, WA 99352

1-888-375-PNNL (7665)

www.pnl.gov 